\title{
19. GEOCHEMISTRY AND MINERALOGY OF BASALTS RECOVERED FROM THE CENTRAL NORTH ATLANTIC ${ }^{1}$
}

\author{
Barry L. Weaver, John Tarney, Department of Geology, University of Leicester, \\ and \\ Andrew D. Saunders, Department of Geology, Bedford College ${ }^{2}$
}

\begin{abstract}
DSDP Leg 82 drilled nine sites to the southwest of the Azores Islands on the west flank of the Mid-Atlantic Ridge (MAR) in an attempt to determine the temporal and spatial evolution of the Azores "hot-spot" activity. The chemistry of the basalts recovered during Leg 82 is extremely varied: in Holes 558 and 561, both enriched (E-type: $\mathrm{Ce}_{\mathrm{N}} / \mathrm{Yb}_{\mathrm{N}}=$ 1.5 to $2.7 ; \mathrm{Zr} / \mathrm{Nb}=4.5$ to 9.6 ) and depleted (or normal- $\mathrm{N}$-type: $\mathrm{Ce}_{\mathrm{N}} / \mathrm{Yb}_{\mathrm{N}}=0.6$ to $0.8 ; \mathrm{Zr} / \mathrm{Nb}>20$ ) mid-ocean ridge basalts (MORB) occur as intercalated lava flows. To the north of the Hayes Fracture Zone, there is little apparent systematic relationship between basalt chemistry and geographic position. However, to the south of the Hayes Fracture Zone, the chemical character of the basalts (N-type MORB) is more uniform.

The coexistence of both E-type and N-type MORB in one hole may be explicable in terms of either complex melting/fractionation processes during basalt genesis or chemically heterogeneous mantle sources. Significant variation in the ratios of strongly incompatible trace elements (e.g., $\mathrm{La} / \mathrm{Ta}$; $\mathrm{Th} / \mathrm{Ta}$ ) in the basalts of Holes 558 and 561 are not easily explicable by processes such as dynamic partial melting or open system crystal fractionation. Rather, the trace element data require that the basalts are ultimately derived from at least two chemically distinct mantle sources.

The results from Leg 82 are equivocal in terms of the evolution of the Azores "hot spot," but would appear not to be compatible with a simple model of E-type MORB magmatism associated with upwelling mantle "blobs." Models that invoke a locally chemically heterogeneous mantle are best able to account for the small-scale variation in basalt chemistry.
\end{abstract}

\section{INTRODUCTION}

The nature of basaltic volcanism at mid-ocean ridges has been well studied in the North Atlantic. Extensive dredging along the axis of the Mid-Atlantic Ridge (MAR) (e.g., Schilling, 1973; White and Schilling, 1978; Bougault and Treuil, 1980; Sigurdsson, 1981) and drilling both near and off the ridge axis (accomplished during many previous DSDP legs) have demonstrated the chemical diversity of basalts that may be erupted at the MAR. Although much of the local variation may be attributable to the effects of physical processes operating during, or subsequent to, magma generation (Langmuir et al., 1977), critical chemical and isotopic features of erupted basalts require regionally heterogeneous mantle sources (White and Schilling, 1978; Wood, Joron, et al., 1979; Wood, Tarney, et al., 1979; Bougault et al., 1980). In the North Atlantic, basalts erupted at normal ridge segments typically display depletion in the light rare earth elements (LREE) and have low ${ }^{87} \mathrm{Sr} /{ }^{86} \mathrm{Sr}$ ratios (Hart, 1971; Schilling, 1971). These have been called normal (or N-type) mid-ocean ridge basalts (Tarney et al., 1980). At anomalous ridge segments, which have high heat flow and elevated topography, the erupted basalts are typically enriched in the LREE and have high ${ }^{87} \mathrm{Sr} /{ }^{86} \mathrm{Sr}$ ratios (Hart et al., 1973; White et al., 1976); these have been called enriched (E-type) MORB (Tarney et al., 1980).

\footnotetext{
${ }^{1}$ Bougault, H., Cande, S. C., et al., Init. Repts. DSDP, 82: Washington (U.S. Govt. Printing Office).

2 Addresses: (Weaver, present address) School of Geology and Geophysics, University of Oklahoma, Norman, Oklahoma 73019; (Tarney and Saunders, present address) Department of Geology, University of Leicester, Leicester LE1 7RH, England.
}

Examples of the former kind of ridge segment occur at $20-34^{\circ} \mathrm{N}$ and $49-59^{\circ} \mathrm{N}$, whereas intervening ridge segments at $34-49^{\circ} \mathrm{N}$ (centered on the Azores platform) and north of $59^{\circ} \mathrm{N}$ (centered on Iceland) are examples of the latter type. The existence of geochemical gradients away from the topographic highs of Iceland and the Azores platform and towards normal ridge segments has been suggested by Schilling $(1973 ; 1975)$ and White and Schilling (1978). Along these "transitional" ridge segments, the basalts appear to display progressively decreasing $\mathrm{La} / \mathrm{Sm}$ and ${ }^{87} \mathrm{Sr} /{ }^{86} \mathrm{Sr}$ ratios away from the hot spots, often interpreted as a large-scale mixing feature between enriched and depleted mantle sources (White and Schilling, 1978; Schilling et al., 1980). However, an alternative model (Wood, Joron, et al., 1979; Tarney et al., 1980) ascribes the chemical variation in MORB to local heterogeneity of mantle source produced by veining of the mantle source of N-type MORB by an enriched component, which may be either an undersaturated melt or a metasomatic fluid.

In attempting to resolve the problem of the scale and causes of mantle heterogeneity in the North Atlantic, the nature of the basalts erupted at "transitional" ridge segments is of great importance. The MAR to the south of the Azores has been extensively studied, particularly in the vicinity of the FAMOUS area at $36^{\circ} \mathrm{N}$, and a considerable data base now exists for basaltic basement recovered by dredging and submersibles (Arcyana, 1977) as well as drilling (DSDP Legs 37 and 49) operations in this region. Additionally, dredging of zero-age basalts from the ridge axis to the south of the Azores has indicated that the Hayes Fracture Zone (Fig. 1) appears to delineate an $\mathrm{N}$-type MORB province to the south from 


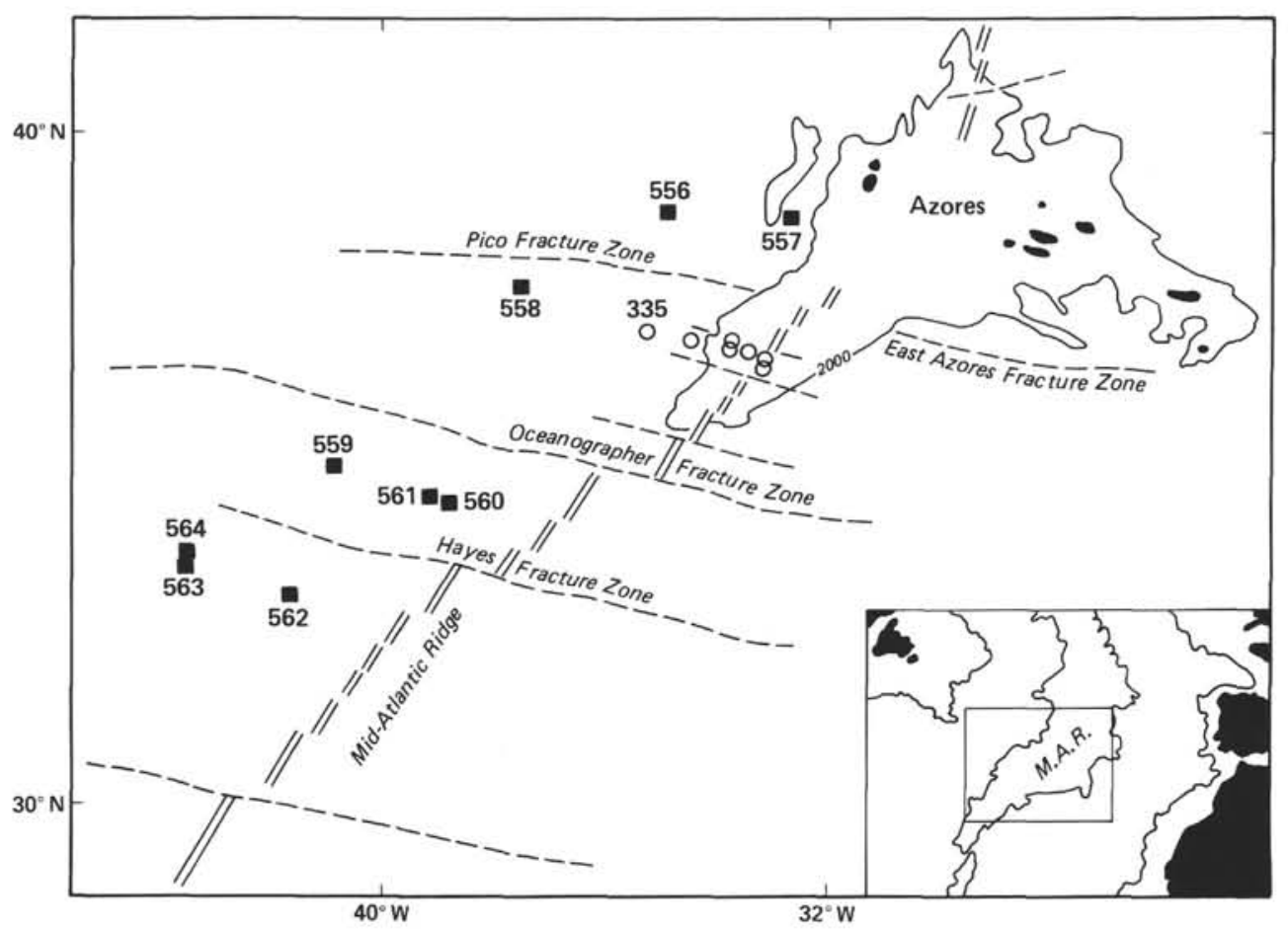

Figure 1. Map of part of the Central North Atlantic showing the location of DSDP Sites 556-564 drilled during Leg 82. Also shown is the location of Site 335 (Leg 37) and the sites drilled near the FAMOUS area during Legs 37 and 49 (open circles).

an E-type MORB province to the north (Bougault and Treuil, 1980). The objective of DSDP Leg 82 was to systematically sample basaltic basement from the west flank of the MAR to the south of the Azores, with the aim of defining the spatial and temporal development and influence of the Azores hot-spot activity. This was achieved by drilling at sites on crust of a particular age $(\sim 18$ and $35 \mathrm{Ma}$ ) on the same mantle flow line and at a number of latitudes (Fig. 1). The most northerly pair of sites are on a flow line through the Azores Triple Junction, and the most southerly to the south of the Hayes Fracture Zone (Fig. 1). In all, Leg 82 drilled at nine sites in this portion of the North Atlantic; Site 335, drilled during Leg 37 on a flow line through the FAMOUS area, was used to complete the grid pattern of sites (Fig. 1).

\section{ANALYTICAL TECHNIQUES}

Seventy-two samples have been analyzed in the present study. The samples were selected on the basis of the chemical groups identified in each hole by the shipboard party. Thus the sampling density is greater in those holes that contain a number of chemical groups. Our new analyses largely confirm the chemical groups identified on board.

The samples were washed in distilled water and dried to remove surface contamination before crushing. The original minicores were then fly-pressed to produce small chips, and this material was ground to a fine powder ( $<240 \mathrm{mesh})$ in an agate Tema swing mill. Any obviously weathered or contaminated (e.g., calcite-filled fractures) material was removed before final crushing. However, in some cases, contamination from calcite-filled vesicles was unavoidable.

For trace element analysis, approximately $15 \mathrm{~g}$ of rock powder was mixed with a binder (an aqueous solution of polyvinyl alcohol) and pressed into $46 \mathrm{~mm}$ powder briquettes. For major element analysis, fusion beads were produced for all samples. The rock powders were heated at approximately $900^{\circ} \mathrm{C}$ for 1 hour and weight losses upon igni- tion were determined. Thus, the reported loss on ignition (LOI) also includes $\mathrm{H}_{2} \mathrm{O}^{-}$, of which no independent estimate was made. The ignited powder $(0.9 \mathrm{~g})$ was mixed with a lithium metaborate/lithium tetraborate flux $(4.5 \mathrm{~g})$ and fused in a vertical tube furnace at $1250^{\circ} \mathrm{C}$. The glass melts were pressed into $46 \mathrm{~mm}$ diameter beads and then stored.

Major and trace element analyses were performed using a Philips PW1400 automatic X-ray fluorescence (XRF) spectrometer at the University of Leicester. The general XRF analytical technique employed has been detailed by Tarney et al. (1979), Marsh et al. (1980), and Weaver et al. (1983). These papers include data for international and internal reference standards by which the high accuracy and precision of the technique can be judged. The trace elements, $\mathrm{Ni}, \mathrm{Zn}, \mathrm{Ga}, \mathrm{Rb}$, $\mathrm{Sr}, \mathrm{Zr}, \mathrm{Nb}$, and $\mathrm{Y}$, were analyzed using a rhodium anode $\mathrm{X}$-ray tube. Mass absorption corrections were applied using the intensity of the $\mathrm{Rh}$ $\mathrm{K}_{\alpha}$ compton scatter line, and calibrations were compared to available international standard rocks. The remaining trace elements, $\mathrm{Cr}, \mathrm{V}, \mathrm{Ba}$, $\mathrm{La}, \mathrm{Ce}$, and $\mathrm{Nd}$, were analyzed using a tungsten anode $\mathrm{X}$-ray tube. Calibrations were measured against basaltic international standards and other well-analyzed basalts. Major element abundances were determined using a rhodium anode $\mathrm{X}$-ray tube calibrated against available international standards. Particular care was taken in the analysis of those petrogenetically important trace elements often present at low abundance levels in basalts. Specifically, very long count times were adopted in order to improve the precision and detection limits for the elements $\mathrm{Nb}, \mathrm{La}, \mathrm{Ce}, \mathrm{Nd}$, and $\mathrm{Rb}$, for which the theoretical $3 \sigma$ lower limits of detection are $0.7,2,4,2$, and $1 \mathrm{ppm}$, respectively.

In addition to the XRF analyses, the freshest sample from each chemical group was selected for analysis for the elements $\mathrm{La}, \mathrm{Ce}, \mathrm{Nd}$, $\mathrm{Sm}, \mathrm{Eu}, \mathrm{Gd}, \mathrm{Tb}, \mathrm{Tm}, \mathrm{Yb}, \mathrm{Lu}, \mathrm{Th}, \mathrm{Ta}$, and Hf by instrumental neutron activation analysis (INAA) techniques at Bedford College, London. Full details of the analytical procedure have been given by Saunders (1983). Only samples from Holes $556,557,558$, and 561 were analyzed by INAA.

Selected mineral analyses were performed using the Cambridge Instruments Microscan V electron microscope, fitted with a Link Systems energy dispersive spectrometer, at the University of Leicester. Standard analytical procedure and full ZAF corrections were applied. 
In general, one thin section from each chemical group was examined, and particular attention was paid to phenocryst compositions as a possible constraint upon crystallization processes.

In the following tables of whole-rock analyses, CIPW norms and $\mathrm{Mg}$-values $\left(100 \mathrm{Mg} /\left[\mathrm{Mg}+\mathrm{Fe}^{2+}\right]\right)$ have been calculated using an assumed $\mathrm{Fe}_{2} \mathrm{O}_{3} / \mathrm{FeO}$ ratio of 0.15 .

\section{SITE 556}

Site $556\left(38^{\circ} 56.38^{\prime} \mathrm{N} ; 34^{\circ} 41.12^{\prime} \mathrm{W}, 3672 \mathrm{~m}\right.$ water depth) lies on Magnetic Anomaly 12 (34 Ma old) on the west flank of the Mid-Atlantic Ridge and is approximately 50 miles north of the Pico Fracture Zone on a flow line passing through the Azores Triple Junction (Fig. 1). A single hole was drilled at this site, and $178 \mathrm{~m}$ of basement (encountered at $461.5 \mathrm{~m}$ sub-bottom depth) was cored before bit failure. A total of nine lithologic units comprising five chemical groups were identified by the shipboard party. The upper $100 \mathrm{~m}$ of basement consists of basalt breccia, pillow basalts, and massive aphyric basalts. The lower $78 \mathrm{~m}$ of basement consists of mylonitized gabbro breccia, which includes a $1 \mathrm{~m}$ interval of aphyric basalt.

Group I basalts make up most of Lithologic Unit 2. The basalts of this group are aphyric but contain rare equant plagioclase phenocrysts (3-5 mm). These phenocrysts are zoned from core compositions of $\mathrm{An}_{88}$ to rim compositions of $\mathrm{An}_{75}$ (Table 1) and contain inclusions of magnesiochromite $\left(\mathrm{Mg} /\left[\mathrm{Mg}+\mathrm{Fe}^{2+}\right]=0.66, \mathrm{Cr} / \mathrm{Cr}\right.$ $+\mathrm{Al}=0.49$; Table 2) and melt (Mg-value $\sim 68)$. Microphenocrysts of clinopyroxene $(\sim 0.5 \mathrm{~mm})$ occur as scattered crystals and have high $\mathrm{Mg}$-values (87) and $\mathrm{Cr}_{2} \mathrm{O}_{3}$ contents $(0.64 \%)$ (Table 3 ). The groundmass has an intergranular texture and consists of 30-35 vol.\% lath to acicular plagioclase $\left(\mathrm{An}_{72}\right.$; Table 1$)$, approximately 40 vol. $\%$ fine-grained $(0.1 \mathrm{~mm})$ aggregates of clinopyroxene $\left(\mathrm{Mg}_{82}\right.$; Table 2) interstitial to the plagioclase, and approximately $5 \mathrm{vol} . \%$ olivine, $3 \mathrm{vol} . \%$ opaques, and 15 vol. \% mesostasis.

Two samples were analyzed from this group (556-2-1, $77-79 \mathrm{~cm}$ and $556-2-2,132-135 \mathrm{~cm}$ ), and the data are presented in Table 4. In terms of the normative components Di-Ol-Hy (Fig. 2), the basalts are low in $\mathrm{Ol}$ and fall quite close to the $\mathrm{Di}-\mathrm{Hy}$ join. The two analyses are very similar (Table 4), have notably high $\mathrm{Mg}$-values (68-69), and very low levels of incompatible trace elements (e.g., $\mathrm{TiO}_{2}, \mathrm{Zr}$; Table 4), implying that these magmas are quite primitive. However, abundances of $\mathrm{Ni}$ and $\mathrm{Cr}$ are lower than anticipated in truly primitive melts, and these basalts must have undergone limited low-pressure crystal fractionation. The basalts of this group are depleted in the more-incompatible trace elements, as illustrated by the high $\mathrm{Zr} / \mathrm{Nb}$ ratios (36-39; Table 4) and low $\mathrm{Ce}_{N} / \mathrm{Y}_{\mathrm{N}}$ ratios (0.4-0.5; Table 4), and are thus typical of rather unfractionated N-type MORB. Rare earth element (REE) data (Table 5) for one of these samples confirms the inferences from trace element data; this sample is strongly depleted in the LREE $\left(\mathrm{Ce}_{\mathrm{N}} / \mathrm{Yb}_{\mathrm{N}}=\right.$ $0.6 ; \mathrm{La}_{\mathrm{N}} / \mathrm{Sm}_{\mathrm{N}}=0.4$; Fig. 3), and has rather low abundances of the REE (Fig. 3).

Group II basalts make up the remainder of Lithologic Unit 2 and all of Unit 3. These basalts are sparsely to moderately plagioclase phyric, with approximately
$2-5$ vol. \% of equant to prismatic plagioclase phenocrysts often occurring in glomerophyric clusters. The phenocrysts are zoned from core compositions of $\mathrm{An}_{87}$ to marginal compositions of $\mathrm{An}_{68}$ (Table 1) and contain melt inclusions. Euhedral olivine microphenocrysts $(\sim 5$ vol. $\%$ ) have a composition of $\mathrm{Fo}_{84}$ (Table 6). The intergranular to almost subophitic textured groundmass consists of approximately subequal (35-40 vol. \%) amounts of swallowtail to narrow lath plagioclase $\left(\mathrm{An}_{70}\right.$; Table 1$)$ and interstitial clinopyroxene. The mesostasis ( 5-10 vol. \%) is altered to clay.

Four samples were analyzed from this group (556-3-1, $57-60 \mathrm{~cm}$; 556-3-2, 49-51 cm; 556-4-2, 65-68 cm; 556$6-4,115-120 \mathrm{~cm}$ ), and the data are presented in Table 4. Normatively, the basalts have small amounts of $\mathrm{Ol}$, as in Group I, but a generally higher $\mathrm{Hy} / \mathrm{Di}$ ratio (Fig. 2). The trend of increase in $\mathrm{Ol}$ and Di relative to Hy (Fig. 2) can be attributed to alteration; the two samples with high LOI and low Mg-values (Table 4) have higher Ol and lower $\mathrm{Hy}$ than the fresher material. These basalts are chemically more evolved than Group I basalts, having lower $\mathrm{Mg}$-values $(\sim 60)$ and higher $\mathrm{TiO}_{2}$ and $\mathrm{Zr}$ abundances (Figs. 4, 5), as well as somewhat lower $\mathrm{Cr}$ and much lower Ni (Table 4). There is some chemical heterogeneity within this group that cannot easily be a result of phenocryst dilution; for example, $\mathrm{TiO}_{2}$ and $\mathrm{Zr}$ vary by approximately $0.1 \%$ and $8 \mathrm{ppm}$, respectively, and yet are not correlated with variation in $\mathrm{Al}_{2} \mathrm{O}_{3}$ or $\mathrm{CaO}$, which would indicate dilution by plagioclase phenocrysts. Basalts of this group display a similar depletion in more incompatible trace elements $(\mathrm{Zr} / \mathrm{Nb}, 28-40$ (Fig. 3); $\mathrm{Ce}_{N} / \mathrm{Y}_{N}, 0.5$ to 0.6 ; Table 4 ) to basalts of Group I. This is illustrated by the REE data for the sample from this group (Table 5), which has a $\mathrm{Ce}_{\mathrm{N}} / \mathrm{Yb}_{\mathrm{N}}$ ratio of 0.6 and a $\mathrm{La}_{\mathrm{N}} / \mathrm{Sm}_{\mathrm{N}}$ ratio of 0.5 comparable to Group I but with greater abundances of the REE (Fig. 3).

Group III comprises Lithologic Units 4, 5, and 6. Much of this sequence is phyric, but some basalts are sparsely to moderately aphyric and scattered plagioclase phenocrysts are common. The phenocrysts range in composition from $\mathrm{An}_{84}$ (core) to $\mathrm{An}_{65}$ (rim) (Table 1) and contain melt inclusions with $\mathrm{Mg}$-values of approximately 70 . Olivine microphenocrysts $(\sim 5 \mathrm{vol} . \%)$ are completely altered to clay. The groundmass has an intersertal texture, comprising approximately $30 \mathrm{vol} . \%$ plagioclase laths, with 40 vol. $\%$ interstitial granular clinopyroxene and $15-20 \mathrm{vol} . \%$ altered mesostasis.

Five samples were analyzed from this group (556-7-1, $115-119 \mathrm{~cm} ; 556-8-1,118-110 \mathrm{~cm}$; 556-9-2, 83-85 cm; $556-10-2,130-133 \mathrm{~cm} ; 556-12-1,68-72 \mathrm{~cm}$ ), and the analyses are presented in Table 4 . These basalts display marked scatter on a normative Di-Ol-Hy diagram (Fig. 2), with very variable $\mathrm{Hy}$; one sample is slightly Ne normative. This variation may be largely due to the effects of alteration or calcite contamination (calcite is common as vesicle and fracture fillings) but may also be partially due to the chemical heterogeneity within this group recognized by the shipboard party. This heterogeneity is apparent in the wide abundance ranges of the incompatible elements (e.g., $\mathrm{TiO}_{2}, 0.77-1.02 \%$; $\mathrm{Zr}, 45-59 \mathrm{ppm}$; 
Table 1. Analyses of plagioclase in Leg 82 basalts.

\begin{tabular}{|c|c|c|c|c|c|c|c|c|c|c|c|c|c|c|c|c|c|c|c|c|c|c|c|}
\hline \multirow{3}{*}{$\begin{array}{l}\text { Hole } \\
\text { Core-Section } \\
\text { (interval in cm) } \\
\text { Chemical group } \\
\text { Type }\end{array}$} & \multicolumn{9}{|c|}{556} & \multirow{2}{*}{\multicolumn{2}{|c|}{$\begin{array}{c}557 \\
1-1,38-41\end{array}$}} & \multirow{2}{*}{\multicolumn{3}{|c|}{$\frac{561}{\substack{2-1, \\
\text { II } \\
\text { I11-116 }}}$}} & \multicolumn{6}{|c|}{562} & \multirow{2}{*}{\multicolumn{3}{|c|}{$\begin{array}{c}563 \\
24-4,0-7\end{array}$}} \\
\hline & \multicolumn{3}{|c|}{$2-2, \underset{I}{132-135}$} & \multicolumn{3}{|c|}{$\begin{array}{c}4-2,65-68 \\
\text { II }\end{array}$} & \multicolumn{2}{|c|}{$\begin{array}{c}10-2,130-133 \\
\text { III }\end{array}$} & \multirow[t]{2}{*}{$\begin{array}{c}16-1, \\
22-25 \\
\mathrm{v}\end{array}$} & & & & & & \multicolumn{3}{|c|}{$\begin{array}{c}3-2,141-143 \\
1\end{array}$} & \multicolumn{3}{|c|}{$\begin{array}{c}8-1,68-71 \\
\text { II }\end{array}$} & & & \\
\hline & $\mathrm{Pc}$ & $\operatorname{Pr}$ & G & $\mathrm{Pc}$ & $\operatorname{Pr}$ & G & $\mathrm{Pc}$ & $\operatorname{Pr}$ & & & & $\mathrm{Pc}$ & Pr & G & $\mathrm{Pc}$ & Pr & G & $\mathrm{Pc}$ & Pr & G & Pc & $\operatorname{Pr}$ & G \\
\hline \multicolumn{24}{|c|}{ Major element (wt.\%) } \\
\hline $\mathrm{SiO}_{2}$ & 46.51 & 49.95 & 51.00 & 46.65 & 52.33 & 51.50 & 47.56 & 52.38 & 52.66 & 53.50 & 65.79 & 50.34 & 50.92 & 52.97 & 46.86 & 52.13 & 51.78 & 45.17 & 49.73 & 50.90 & 45.88 & 48.89 & 50.81 \\
\hline $\mathrm{Al}_{2} \mathrm{O}_{3}$ & 33.38 & 30.76 & 30.38 & 33.40 & 29.40 & 30.02 & 33.15 & 29.25 & 29.75 & 28.39 & 26.79 & 30.64 & 30.32 & 28.67 & 33.29 & 29.72 & 29.74 & 34.34 & 31.04 & 30.26 & 33.85 & 31.60 & 30.05 \\
\hline $\mathrm{FeO}$ & 0.29 & 0.53 & 0.59 & 0.38 & 0.71 & 0.67 & אוז. & 1.00 & 0.24 & 0.81 & 0.71 & 0.46 & 0.54 & 1.08 & 0.38 & 0.74 & 0.83 & 54.04 & 0.64 & 0.72 & 0.27 & 0.70 & 0.83 \\
\hline $\mathrm{CaO}$ & 18.08 & 15.30 & 14.95 & 17.94 & 13.84 & 14.53 & 17.39 & 13.22 & 12.66 & 12.07 & 9.44 & 15.01 & 14.53 & 13.10 & 17.44 & 13.68 & 13.66 & 18.85 & 15.54 & 14.89 & 18.43 & 16.17 & 14.66 \\
\hline $\begin{array}{l}\mathrm{Na}_{2} \mathrm{O} \\
\mathrm{K}_{2} \mathrm{O}\end{array}$ & 1.40 & 2.87 & 3.21 & 1.51 & 3.65 & 3.37 & 1.77 & 3.94 & 4.38 & $\begin{array}{l}4.55 \\
0.14\end{array}$ & $\begin{array}{l}5.75 \\
0.21\end{array}$ & 3.03 & 3.30 & 4.00 & 1.70 & 3.67 & 3.81 & 1.08 & 2.71 & 3.17 & 1.13 & 2.23 & 3.31 \\
\hline Total & 99.66 & 99.41 & 100.13 & 99.88 & 99.93 & 100.09 & 99.87 & 99.79 & 99.69 & 99.46 & 99.69 & 99.48 & 99.61 & 99.82 & 99.77 & 99.94 & 99.82 & 99.44 & 99.66 & 99.94 & 99.56 & 99.59 & 99.66 \\
\hline \multicolumn{24}{|c|}{ Formula on the basis of 8 oxygens } \\
\hline $\mathrm{Si}$ & 2.150 & 2.298 & 2.327 & 2.153 & 2.384 & 2.348 & 2.185 & 2.390 & 2.394 & 2.441 & 2.561 & 2.311 & 2.332 & 2.415 & 2.162 & 2.374 & 2.365 & 2.097 & 2.284 & 2.238 & 2.215 & 2.251 & 2.331 \\
\hline $\mathrm{Al}$ & 1.820 & 1.668 & 1.643 & 1.817 & 1.579 & 1.613 & 1.796 & 1.574 & 1.595 & 1.527 & 1.424 & 1.658 & 1.637 & 1.541 & 1.816 & 1.596 & 1.601 & 1.880 & 1.681 & 1.631 & 1.849 & 1.715 & 1.625 \\
\hline $\mathrm{Fe}$ & 0.011 & 0.020 & 0.023 & 0.015 & 0.027 & 0.026 & & 0.038 & 0.009 & 0.031 & 0.027 & 0.018 & 0.021 & 0.041 & 0.015 & 0.028 & 0.032 & 1.000 & 0.024 & 0.028 & 0.011 & 0.027 & 0.032 \\
\hline $\mathrm{Ca}$ & 0.896 & 0.754 & 0.731 & 0.887 & 0.675 & 0.710 & 0.856 & 0.647 & 0.617 & 0.590 & 0.456 & 0.738 & 0.713 & 0.640 & 0.862 & 0.667 & 0.668 & 0.938 & 0.765 & 0.730 & 0.915 & 0.798 & 0.721 \\
\hline $\mathrm{Na}$ & 0.126 & 0.256 & 0.284 & 0.1325 & 0.322 & 0.298 & 0.158 & 0.349 & 0.386 & 0.403 & 0.503 & 0.270 & 0.293 & 0.354 & 0.152 & 0.324 & 0.337 & 0.097 & 0.242 & 0.281 & 0.101 & 0.200 & 0.295 \\
\hline $\begin{array}{l}K \\
\text { An }\end{array}$ & 88 & 75 & 72 & 87 & 68 & 70 & 84 & 65 & 62 & 59 & 48 & 73 & 71 & 64 & 85 & 67 & 66 & 91 & 76 & 72 & 90 & 80 & 71 \\
\hline
\end{tabular}

Note: $\mathrm{Pc}=$ phenocryst core; $\operatorname{Pr}=$ phenocryst rim; $\mathrm{G}=$ groundmass. 
Table 2. Analyses of magnesiochromite from Holes 556 and 562.

\begin{tabular}{|c|c|c|c|c|c|}
\hline \multirow{3}{*}{$\begin{array}{l}\text { Hole } \\
\text { Core-Section } \\
\text { (interval in } \mathrm{cm} \text { ) }\end{array}$} & \multirow{2}{*}{\multicolumn{2}{|c|}{$\frac{556}{2-2,132-135 \text { (I) }}$}} & \multicolumn{3}{|c|}{562} \\
\hline & & & \multicolumn{2}{|c|}{$3-2,141-143$ (I) } & \multirow{2}{*}{$\begin{array}{l}8-1,68-71 \\
\text { (II) }\end{array}$} \\
\hline & (1) & (2) & (1) & (2) & \\
\hline \multicolumn{6}{|l|}{ Major element (wt.\%) } \\
\hline $\mathrm{SiO}_{2}$ & 0.70 & 0.43 & 0.45 & 0.44 & 0.79 \\
\hline $\mathrm{TiO}_{2}$ & 0.32 & 0.48 & 0.43 & 0.31 & 0.31 \\
\hline $\mathrm{Al}_{2} \mathrm{O}_{3}$ & 26.89 & 28.35 & 29.75 & 28.86 & 32.20 \\
\hline $\mathrm{Cr}_{2} \mathrm{O}_{3}$ & 38.74 & 39.00 & 36.56 & 37.77 & 34.66 \\
\hline $\mathrm{Fe}_{2} \mathrm{O}_{3}$ & 4.78 & 4.08 & 5.17 & 4.74 & 5.15 \\
\hline $\mathrm{FeO}$ & 14.04 & 12.33 & 12.63 & 13.36 & 9.68 \\
\hline $\mathrm{MgO}$ & 14.20 & 15.65 & 15.68 & 15.31 & 17.73 \\
\hline Total & 99.67 & 100.32 & 100.85 & 100.79 & 100.52 \\
\hline \multicolumn{6}{|l|}{ Formula on the basis of 4 oxygens } \\
\hline $\mathrm{Si}$ & 0.021 & 0.013 & 0.013 & 0.013 & 0.023 \\
\hline $\mathrm{Ri}$ & 0.007 & 0.011 & 0.010 & 0.007 & 0.007 \\
\hline Al & 0.962 & 0.993 & 1.035 & 1.010 & 1.096 \\
\hline $\mathrm{Cr}$ & 0.929 & 0.916 & 0.853 & 0.887 & 0.791 \\
\hline $\mathrm{Fe}_{2+}^{3+}$ & 0.109 & 0.091 & 0.115 & 0.106 & 0.112 \\
\hline $\mathrm{Fe}^{2+}$ & 0.356 & 0.306 & 0.312 & 0.332 & 0.234 \\
\hline $\mathrm{Mg}$ & 0.642 & 0.693 & 0.697 & 0.677 & 0.763 \\
\hline $\mathrm{Mg} /\left(\mathrm{Mg}+\mathrm{Fe}^{2+}\right)$ & 0.643 & 0.694 & 0.691 & 0.671 & 0.765 \\
\hline $\mathrm{Cr} /(\mathrm{Cr}+\mathrm{Al})$ & 0.491 & 0.480 & 0.452 & 0.468 & 0.419 \\
\hline $\mathrm{Fe}^{3+} /\left(\mathrm{Fe}^{3+}+\mathrm{Cr}+\mathrm{Al}\right)$ & 0.055 & 0.046 & 0.057 & 0.053 & 0.056 \\
\hline Host plag. & An 88 & Angs & An$_{87}$ & An85 & Ango \\
\hline
\end{tabular}

Note: Roman numerals in parentheses are chemical group numbers. Arabic numbers in parentheses are lithologic unit numbers; plag. = plagioclase.

Table 4). To a certain extent this variation can be modeled by phenocryst dilution, as the model in Table 7 illustrates, but such models cannot be applied successfully to all basalts of this group, because many are aphyric. Compositionally, the aphyric samples of this group are similar to basalts of Group I, at least in terms of the abundances of incompatible elements (e.g., $\mathrm{Zr}, \mathrm{Nb}, \mathrm{TiO}_{2}$; Table 4; Figs. 4, 5). However, Mg-values are lower, as are $\mathrm{Ni}$ abundances (Table 4), whereas the $\mathrm{Ti} / \mathrm{Zr}$ ratio of this group is lower (Fig. 5). $\mathrm{Zr} / \mathrm{Nb}$ ratios (25-41; Table 4) are high and $\mathrm{Ce}_{\mathrm{N}} / \mathrm{Y}_{\mathrm{N}}$ ratios low (0.4-0.7; Table 4), indicating that Group III basalts are as depleted in the more incompatible trace elements as Groups I and II.

Group IV comprises part of Lithologic Unit 7 and all of Lithologic Unit 9; the two parts of this group are separated by an interval of Group III basalts and Group IV gabbro. These basalts are aphyric and lack olivine. The texture is subophitic with subequal proportions of plagioclase laths and interstitial granular clinopyroxene, plus mesostasis.

Two samples were analyzed (556-12-1, 68-72 $\mathrm{cm}$ and 556-16-2, 128-131 cm) and the data are given in Table 4. Sample 556-12-1, 68-72 cm is normatively similar to the basalt of Groups I and II (Fig. 2), with a low proportion of normative Ol. Sample 556-16-2, 128-131 cm, however, has higher normative $\mathrm{Ol}$ and lower $\mathrm{Hy}$ and is somewhat more altered than 556-12-1, 68-72 cm, with a higher LOI and lower Mg-value (Table 4). The levels of the incompatible elements are quite high (Table 4), though slightly lower than in Group II (Figs. 4, 5). The Mg-values are rather low ( $\sim 58$, Table 4$)$ and similar to those in Group II. However, a striking feature of these basalts is the very low abundances of $\mathrm{Ni}(\sim 40 \mathrm{ppm})$ and $\mathrm{Cr}$ $(\sim 50 \mathrm{ppm})($ Table 4$)$ indicative of a rather evolved na-

Table 3. Analyses of clinopyroxene from Holes 556, 557, and 563 and clinopyroxene and orthopyroxene from the gabbro of Hole 556.

\begin{tabular}{|c|c|c|c|c|c|c|c|c|}
\hline \multirow{2}{*}{$\begin{array}{l}\text { Hole } \\
\text { Core-Section } \\
\text { (interval in cm) } \\
\text { Type }\end{array}$} & \multicolumn{2}{|c|}{$\begin{array}{c}556 \\
2-2,132-135(\mathrm{I})\end{array}$} & \multicolumn{2}{|c|}{$\begin{array}{c}563 \\
24-4,0-7\end{array}$} & \multirow[t]{2}{*}{$\begin{array}{c}557 \\
1-1,38-41\end{array}$} & \multicolumn{3}{|c|}{$\begin{array}{c}556 \\
16-1,22-25(\mathrm{~V})\end{array}$} \\
\hline & $\mathrm{Mp}$ & G & $\mathrm{Mp}$ & G & & Cpx & Opx & Opx \\
\hline \multicolumn{9}{|c|}{ Major elements (wt.\%) } \\
\hline $\mathrm{SiO}_{2}$ & 52.84 & 51.57 & 50.99 & 50.65 & 49.05 & 52.01 & 53.91 & 51.40 \\
\hline $\mathrm{TiO}_{2}$ & 0.41 & 0.71 & 0.57 & 0.71 & 1.74 & 0.44 & 0.34 & 0.25 \\
\hline $\mathrm{Al}_{2} \mathrm{O}_{3}$ & 2.58 & 3.76 & 4.10 & 4.55 & 3.13 & 2.27 & 1.16 & 0.68 \\
\hline $\mathrm{FeO}$ & 4.93 & 7.47 & 5.86 & 6.72 & 11.15 & 8.43 & 15.78 & 25.21 \\
\hline $\mathrm{MnO}$ & & 0.25 & & 0.21 & 0.29 & & 0.28 & 0.82 \\
\hline $\mathrm{MgO}$ & 18.19 & 18.47 & 17.03 & 16.86 & 14.18 & 15.41 & 26.33 & 19.67 \\
\hline $\mathrm{CaO}$ & 20.42 & 17.84 & 20.45 & 19.77 & 19.38 & 20.80 & 2.10 & 1.68 \\
\hline $\mathrm{Na}_{2} \mathrm{O}$ & & & & 0.39 & 0.56 & 0.55 & & \\
\hline $\mathrm{Cr}_{2} \mathrm{O}_{3}$ & 0.64 & & 0.77 & & & & & \\
\hline Total & 100.01 & 100.07 & 99.77 & 99.86 & 99.48 & 99.91 & 99.90 & 99.71 \\
\hline \multicolumn{9}{|c|}{ Formula on the basis of 6 oxygens } \\
\hline $\mathrm{Si}$ & 1.925 & 1.887 & 1.875 & 1.866 & 1.860 & 1.932 & 1.957 & 1.961 \\
\hline $\mathrm{Ti}$ & 0.011 & 0.020 & 0.016 & 0.020 & 0.050 & 0.012 & 0.009 & 0.007 \\
\hline $\mathrm{Al}$ & 0.011 & 0.162 & 0.178 & 0.197 & 0.140 & 0.100 & 0.050 & 0.031 \\
\hline $\mathrm{Fe}$ & 0.150 & 0.229 & 0.180 & 0.207 & 0.354 & 0.262 & 0.479 & 0.804 \\
\hline $\mathrm{Mn}$ & & 0.008 & & 0.007 & 0.009 & & 0.009 & 0.026 \\
\hline $\mathrm{Mg}$ & 0.987 & 1.007 & 0.933 & 0.926 & 0.801 & 0.853 & 1.424 & 1.118 \\
\hline $\mathrm{Ca}$ & 0.797 & 0.700 & 0.806 & 0.780 & 0.787 & 0.828 & 0.082 & 0.069 \\
\hline $\mathrm{Na}$ & & & & 0.028 & 0.041 & 0.039 & & \\
\hline $\mathrm{Cr}$ & 0.018 & & 0.022 & & & & & \\
\hline $\mathrm{Mg} /(\mathrm{Mg}+\mathrm{Fe})$ & 0.87 & 0.81 & 0.84 & 0.82 & 0.69 & 0.77 & 0.75 & 0.58 \\
\hline Wo & 39.2 & 33.9 & 39.4 & 39.8 & 41.5 & 43.5 & 2.9 & 2.7 \\
\hline En & 52.8 & 55.2 & 52.1 & 53.1 & 45.1 & 46.5 & 73.4 & 57.3 \\
\hline Fs & 2.0 & 10.9 & 8.5 & 7.1 & 13.4 & 10.0 & 23.7 & 40.0 \\
\hline
\end{tabular}

Note: $\mathrm{Mp}=$ microphenocryst $; \mathrm{G}=$ groundmass; $\mathrm{Cpx}=$ clinopyroxene; Opx = orthopyroxene. Roman numerals in parentheses are chemical group numbers. 
Table 4. Major and trace element analyses of basalts and gabbro from Hole 556.

\begin{tabular}{|c|c|c|c|c|c|c|c|c|c|c|c|c|c|c|}
\hline \multirow{3}{*}{$\begin{array}{l}\text { Chemical group } \\
\text { Core-Section } \\
\text { (interval in cm) } \\
\text { Piece number }\end{array}$} & \multicolumn{2}{|c|}{1} & \multicolumn{4}{|c|}{ II } & \multicolumn{4}{|c|}{ III } & \multirow{2}{*}{ 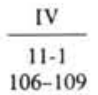 } & \multirow{2}{*}{$\frac{\text { III }}{\begin{array}{c}12-1 \\
68-72\end{array}}$} & \multirow{2}{*}{ 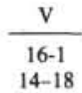 } & \multirow{2}{*}{$\begin{array}{c}\text { IV } \\
16-2 \\
128-131\end{array}$} \\
\hline & $\begin{array}{c}2-1 \\
77-79\end{array}$ & $\begin{array}{c}2-2 \\
132-135\end{array}$ & $\begin{array}{c}3-1 \\
57-60\end{array}$ & $\begin{array}{c}3-2 \\
49-51\end{array}$ & $\begin{array}{c}4-2 \\
65-68\end{array}$ & $\begin{array}{c}6-4 \\
115-120\end{array}$ & $\begin{array}{c}7-1 \\
115-119\end{array}$ & $\begin{array}{c}8-1 \\
118-120\end{array}$ & $\begin{array}{c}9-2 \\
83-85\end{array}$ & $\begin{array}{c}10-2 \\
130-133\end{array}$ & & & & \\
\hline & $4 \mathrm{e}$ & $9 \mathrm{a}$ & 7 & $4 \mathrm{~b}$ & $2 \mathrm{a}$ & $5 b$ & $5 a$ & $8 a$ & $4 b$ & $3 b$ & 13 & $4 c$ & $3 a$ & 15 \\
\hline \multicolumn{15}{|c|}{ Major elements (wt. \%) } \\
\hline $\mathrm{SiO}_{2}$ & 50.56 & 50.02 & 49.02 & 49.66 & 48.62 & 49.73 & 48.46 & 49.25 & 49.78 & 47.95 & 50.35 & 49.01 & 52.10 & 49.08 \\
\hline $\mathrm{TiO}_{2}^{2}$ & 1.04 & 1.02 & 1.46 & 1.41 & 1.45 & 1.37 & 0.99 & 0.83 & 1.02 & 0.77 & 1.31 & 0.84 & 0.26 & 1.33 \\
\hline $\mathrm{Al}_{2} \mathrm{O}_{3}$ & 15.96 & 15.65 & 15.61 & 15.76 & 15.93 & 15.26 & 15.21 & 15.44 & 15.43 & 17.09 & 15.00 & 16.44 & 18.14 & 14.35 \\
\hline $\mathrm{Fe}_{2} \mathrm{O}_{3}$ & 7.83 & 8.44 & 10.55 & 10.37 & 10.36 & 10.75 & 9.74 & 8.81 & 9.55 & 8.08 & 10.42 & 8.44 & 5.73 & 11.32 \\
\hline $\mathrm{MnO}$ & 0.15 & 0.15 & 0.17 & 0.18 & 0.17 & 0.16 & 0.16 & 0.15 & 0.16 & 0.15 & 0.18 & 0.15 & 0.11 & 0.17 \\
\hline $\mathrm{MgO}$ & 7.89 & 8.04 & 6.53 & 6.84 & 6.02 & 7.20 & 7.62 & 7.62 & 7.04 & 7.15 & 6.44 & 8.18 & 8.89 & 6.49 \\
\hline $\mathrm{CaO}$ & 12.74 & 12.42 & 11.39 & 11.34 & 11.51 & 11.35 & 12.65 & 13.27 & 12.63 & 13.73 & 10.86 & 12.39 & 11.92 & 10.61 \\
\hline $\mathrm{Na}_{2} \mathrm{O}$ & 2.44 & 2.49 & 2.70 & 2.65 & 1.76 & 2.67 & 2.56 & 2.33 & 2.52 & 2.41 & 2.96 & 2.31 & 2.62 & 3.11 \\
\hline $\mathrm{K}_{2} \mathrm{O}$ & 0.16 & 0.17 & 0.28 & 0.28 & 0.28 & 0.10 & 0.22 & 0.36 & 0.35 & 0.21 & 0.45 & 0.20 & 0.07 & 0.48 \\
\hline $\mathrm{P}_{2} \mathrm{O}_{5}$ & 0.11 & 0.12 & 0.15 & 0.14 & 0.14 & 0.13 & 0.09 & 0.10 & 0.11 & 0.08 & 0.13 & 0.08 & 0.02 & 0.13 \\
\hline LOีI & 1.65 & 1.74 & 2.27 & 1.55 & 3.07 & 1.54 & 1.94 & 2.35 & 1.63 & 2.01 & 1.97 & 2.28 & 0.71 & 2.61 \\
\hline Total & 100.53 & 100.26 & 100.13 & 100.18 & 100.31 & 100.26 & 99.64 & 100.51 & 100.22 & 99.63 & 100.07 & 100.32 & 100.57 & 99.68 \\
\hline
\end{tabular}

Trace elements (ppm)

\begin{tabular}{|c|c|c|c|c|c|c|c|c|c|c|c|c|c|c|}
\hline $\mathrm{Cr}$ & 326 & 336 & 284 & 287 & 300 & 277 & 379 & 298 & 127 & 439 & 48 & 400 & 84 & 47 \\
\hline $\mathrm{Ni}$ & 140 & 153 & 70 & 72 & 69 & 71 & 92 & 96 & 68 & 106 & 40 & 97 & 80 & 41 \\
\hline v & 267 & 268 & 292 & 280 & 304 & 274 & 239 & 260 & 286 & 218 & 320 & 225 & 148 & 306 \\
\hline $\mathrm{Zn}$ & 74 & 72 & 87 & 85 & 89 & 78 & 71 & 68 & 73 & 58 & 90 & 60 & 39 & 84 \\
\hline $\mathrm{Ga}$ & 16 & 16 & 17 & 17 & 17 & 18 & 16 & 14 & 17 & 15 & 17 & 15 & 14 & 19 \\
\hline $\mathrm{Rb}$ & 2 & 2 & 6 & 4 & 5 & 2 & 4 & 6 & 6 & 4 & 9 & 3 & $<1$ & 8 \\
\hline $\mathrm{Sr}$ & 112 & 107 & 102 & 100 & 101 & 97 & 103 & 99 & 102 & 98 & 110 & 95 & 94 & 114 \\
\hline $\mathrm{Ba}$ & 30 & 29 & 24 & 24 & 15 & 25 & 16 & 27 & 18 & 19 & 31 & 17 & 9 & 45 \\
\hline $\mathrm{Zr}$ & 62 & 61 & 92 & 90 & 93 & 85 & 55 & 48 & 59 & 45 & 79 & 49 & 9 & 79 \\
\hline $\mathrm{Nb}$ & 1.6 & 1.7 & 3.3 & 2.8 & 2.8 & 2.1 & 1.5 & 1.6 & 2.4 & 1.1 & 2.6 & 1.6 & $<1$ & 1.9 \\
\hline $\mathrm{La}$ & 2 & 2 & 2 & 3 & 3 & 3 & 2 & 2 & 2 & $<2$ & 3 & $<2$ & $<2$ & 3 \\
\hline $\mathrm{Ce}$ & 6 & 5 & 8 & 9 & 8 & 8 & 6 & 5 & 5 & 4 & 10 & 6 & $<4$ & 9 \\
\hline Nd & 7 & 7 & 9 & 9 & 9 & 9 & 6 & 6 & 7 & 5 & 9 & 7 & 2 & 8 \\
\hline $\mathrm{Y}$ & 26 & 26 & 36 & 34 & 36 & 34 & 25 & 22 & 26 & 19 & 33 & 21 & 9 & 32 \\
\hline
\end{tabular}

Selected element ratios

$\begin{array}{lcc}\mathrm{Mg} \text {-value } & 69 & 68 \\ \mathrm{Ti} / \mathrm{Zr} & 101 & 100 \\ \mathrm{Zr} / \mathrm{Nb} & 39 & 36 \\ \mathrm{Ce} / \mathrm{Y}_{\mathrm{N}} & 0.5 & 0.4 \\ \mathrm{Zr} / \mathrm{Ce} & 11 & 13 \\ \mathrm{Zr} / \mathrm{Y} & 2.5 & 2.5\end{array}$

$\begin{array}{ccccc}58 & 60 & 57 & 60 & 64 \\ 95 & 94 & 93 & 97 & 108 \\ 28 & 32 & 33 & 40 & 37 \\ 0.5 & 0.6 & 0.5 & 0.5 & 0.6 \\ 12 & 10 & 12 & 11 & 10 \\ 2.7 & 2.8 & 2.7 & 2.6 & 2.3\end{array}$

$\begin{array}{ccc}66 & 62 & 66 \\ 104 & 104 & 103 \\ 30 & 25 & 41 \\ 0.5 & 0.4 & 0.5 \\ 10 & 12 & 12 \\ 2.3 & 2.3 & 2.5\end{array}$

$\begin{array}{lccc}58 & 69 & 78 & 56 \\ 99 & 103 & 172 & 101 \\ 30 & 31 & & 42 \\ 0.7 & 0.7 & & 0.7 \\ 8.2 & 8.5 & & 9.1 \\ 2.5 & 2.4 & 1.0 & 2.6\end{array}$

CIPW norms

\begin{tabular}{|c|c|c|c|c|c|c|c|c|c|c|c|c|c|c|}
\hline Or & 1.0 & 1.0 & 1.7 & 1.7 & 1.7 & 0.6 & 1.4 & 2.2 & 2.1 & 1.3 & 2.7 & 1.2 & 0.4 & 2.9 \\
\hline $\mathrm{Ab}$ & 20.9 & 21.4 & 23.4 & 22.8 & 24.0 & 22.9 & 22.2 & 20.1 & 21.7 & 20.5 & 25.6 & 20.0 & 22.2 & 27.1 \\
\hline An & 32.5 & 31.5 & 30.3 & 30.7 & 31.1 & 29.8 & 30.1 & 31.2 & 30.2 & 36.1 & 26.8 & 34.6 & 37.6 & 24.5 \\
\hline $\mathrm{Ne}$ & & & & & & & & & & 0.2 & & & & \\
\hline $\mathrm{Di}$ & 24.7 & 24.5 & 21.7 & 20.8 & 21,9 & 21.6 & 27.4 & 28.5 & 26.7 & 26.9 & 22.3 & 22.3 & 17.2 & 23.7 \\
\hline $\mathrm{Hy}$ & 14.9 & 13.0 & 12.9 & 15.4 & 10.8 & 16.8 & 3.8 & 6.6 & 9.7 & & 14.4 & 11.0 & 18.1 & 7.5 \\
\hline OI & 1.7 & 4.1 & 4.1 & 2.8 & 4.6 & 2.6 & 10.5 & 7.2 & 5.0 & 11.2 & 2.6 & 6.9 & 2.4 & 8.4 \\
\hline Mt & 1.4 & 1.5 & 1.9 & 1.8 & 1.8 & 1.9 & 1.7 & 1.6 & 1.7 & 1.4 & 1.8 & 1.5 & 1.0 & 2.0 \\
\hline II & 2.0 & 2.0 & 2.8 & 2.7 & 2.8 & 2.6 & 1.9 & 1.6 & 2.0 & 1.5 & 2.5 & 1.6 & 0.5 & 2.6 \\
\hline Ap & 0.3 & 0.3 & 0.4 & 0.3 & 0.4 & 0.3 & 0.2 & 0.3 & 0.3 & 0.2 & 0.3 & 0.2 & 0.1 & 0.3 \\
\hline
\end{tabular}

Note: $\mathrm{LOI}$ is loss on ignition. Total iron is expressed as $\mathrm{Fe}_{2} \mathrm{O}_{3}$. CIPW norms and $\mathrm{Mg}$-values $\left(100 \mathrm{Mg} /\left[\mathrm{Mg}+\mathrm{Fe}^{2+}\right]\right)$ are calculated using an assumed $\mathrm{Fe}_{2} \mathrm{O}_{3} / \mathrm{FeO}$ ratio of 0.15 . Ce $\mathrm{N}^{\prime}$ $\mathrm{Y}_{\mathrm{N}}$ expresses the chondrite-normalized ratio of $\mathrm{Ce}$ to $\mathrm{Y}$.

ture for this group. The depletion in more incompatible elements $\left(\mathrm{Zr} / \mathrm{Nb} 30-42, \mathrm{Ce}_{\mathrm{N}} / \mathrm{Y}_{\mathrm{N}} 0.7\right.$; Table 4$)$ is comparable to that in the other chemical groups of this hole.

Group V comprises Lithologic Units 8 and 10. The gabbros of this group have a uniform grain size but variable mineralogy; orthopyroxene contents range from 5-20 vol. \% and clinopyroxene from $35-15$ vol. \% . In little deformed and fresh gabbros the plagioclase is up to $4 \mathrm{~mm}$ in size, though more commonly $1-2 \mathrm{~mm}$, and is unzoned, with a uniform composition of $\mathrm{An}_{62}$ (Table 1). Clinopyroxene occurs as large (commonly 3-7 mm) prismatic grains that show extensive exsolution and twinning and have a composition of $\mathrm{Wo}_{44} \mathrm{En}_{47} \mathrm{Fs}_{10}$ (Table 3). Orthopyroxene occurs as slightly smaller (commonly $2-4 \mathrm{~mm}$ ) subhedral or prismatic grains and displays a range of variation from magnesian $\left(\mathrm{Wo}_{3} \mathrm{En}_{73} \mathrm{Fs}_{24}\right.$; Table 3) to more iron-rich $\left(\mathrm{Wo}_{3} \mathrm{En}_{57} \mathrm{Fs}_{40}\right.$; Table 3) composition. Occasional unaltered pleochroic amphibole grains also occur. Upon shearing, the plagioclase becomes granulated, often very finely, whereas the pyroxenes retain their original size but become strained, granulation only occurring in the presence of intensive shearing. Upon alteration, the pyroxenes change to a colorless-to-green fibrous amphibole and chlorite.

Only one sample was analyzed from this group, and the analysis is given in Table 4 . Normatively this sample has a high plagioclase content $(60 \%$; the normative composition $\left(\mathrm{An}_{63}\right)$ is very close to the observed composition) and $35 \%$ total pyroxene. The Mg-value is very high (78; Table 4) and similar to that of the pyroxenes (Table 3). 


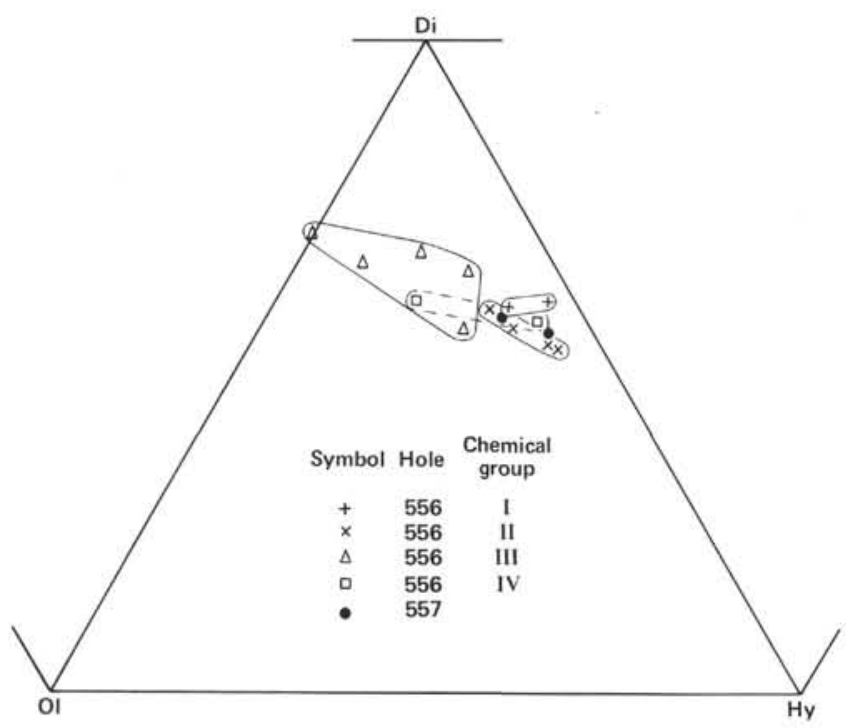

Figure 2. Plot of normative components Ol-Di-Hy for basalts from Holes 556 and 557. Norms are calculated using an $\mathrm{Fe}_{2} \mathrm{O}_{3} / \mathrm{FeO}$ ratio of 0.15 .

This, combined with the high $\mathrm{Al}_{2} \mathrm{O}_{3}$ and $\mathrm{CaO}$ contents and low abundances of incompatible elements $\mathrm{Ti}$ and $\mathrm{Zr}$ (Table 4) clearly indicates the cumulate nature of this gabbro. The very high $\mathrm{Ti} / \mathrm{Zr}$ ratio (172; Table 4) reflects the control of $\mathrm{TiO}_{2}$ abundance in the whole rock by cumulus pyroxene, and the high $\mathrm{Sr} / \mathrm{Zr}$ ratio (10 compared to 1-2.1 in basalt of Groups I to IV) reflects the control of $\mathrm{Sr}$ abundance by cumulus plagioclase.

This gabbro unit is very different from the gabbros recovered from Hole 334, which contain very calcic pla-

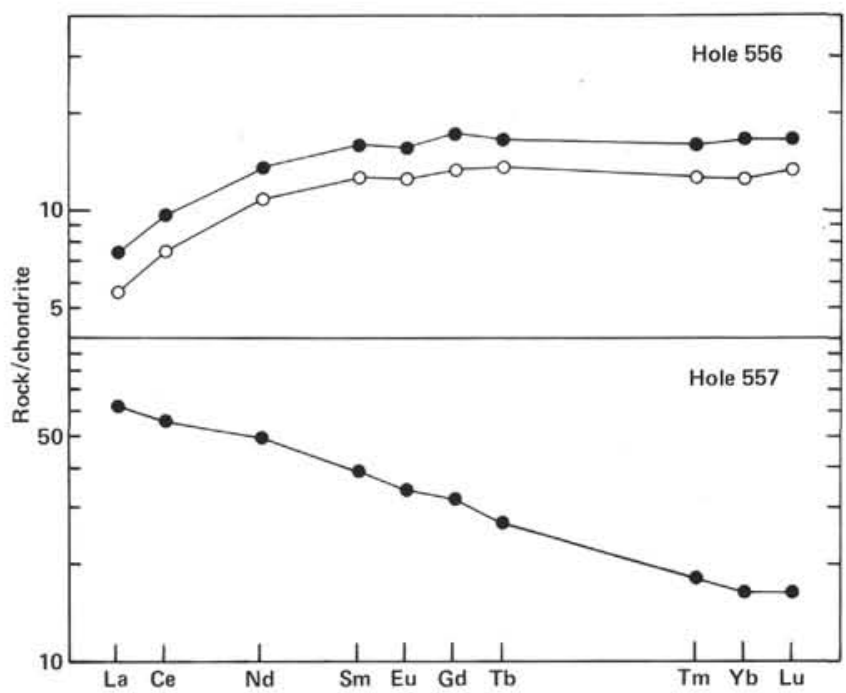

Figure 3. Abundances of the rare earth elements in basalts of Holes 556 and 557 normalized to the average chondrite values of Nakamura (1974). Closed circle = Group I, Hole 556; open circle = Group II, Hole 556.

gioclase $\left(\mathrm{An}_{80}\right)$ and magnesian pyroxenes $\left(\mathrm{Mg}_{87}\right)($ Clarke and Loubat, 1977; Symes et al., 1977). They are, however, comparable to gabbroic rocks recovered from the Mathematician Ridge in the East Pacific (Vanko and Batiza, 1982). The mineral chemistry indicates that the Hole 556 gabbros must have been derived from rather evolved basalts. Applying Fe-Mg distribution coefficients between clinopyroxene and liquid derived for FAMOUS basalts (Bryan, 1979), the Mg-value of the liquid precipitating the clinopyroxene of Table 3 is 49 (all $\mathrm{Fe}$ in clino-

Table 5. INAA results for Leg 82 basalts.

\begin{tabular}{|c|c|c|c|c|c|c|c|c|c|c|}
\hline \multirow{3}{*}{$\begin{array}{l}\text { Hole } \\
\text { Core-Section } \\
\text { (interval in cm) } \\
\text { Chemical group }\end{array}$} & \multicolumn{2}{|c|}{556} & \multirow{3}{*}{$\frac{557}{1-1}$} & \multicolumn{5}{|c|}{558} & \multicolumn{2}{|c|}{561} \\
\hline & $\begin{array}{c}2-1 \\
77-79\end{array}$ & $\begin{array}{c}6-4 \\
115-120\end{array}$ & & $\begin{array}{c}27-3 \\
92-95\end{array}$ & $\begin{array}{c}28-3 \\
36-38\end{array}$ & $\begin{array}{c}31-1 \\
86-89\end{array}$ & $\begin{array}{c}35-1 \\
120-122\end{array}$ & $\begin{array}{c}39-2 \\
69-71\end{array}$ & $\begin{array}{c}1-1 \\
44-47\end{array}$ & $\begin{array}{c}1-2 \\
22-24\end{array}$ \\
\hline & I & II & & & II & III & IV & V & I & II \\
\hline \multicolumn{11}{|l|}{ Elements (ppm) } \\
\hline $\mathrm{La}$ & 1.84 & 2.44 & 20.0 & 6.05 & 2.68 & 10.6 & 6.62 & 5.24 & 14.1 & 3.04 \\
\hline $\mathrm{Ce}$ & 6.45 & 8.38 & 47.3 & 15.2 & 8.52 & 22.9 & 16.3 & 12.7 & 30.1 & 8.88 \\
\hline $\mathrm{Nd}$ & 6.88 & 8.55 & 31.0 & 9.39 & 7.54 & 13.7 & 10.1 & 8.32 & 16.3 & 9.22 \\
\hline $\mathrm{Sm}$ & 2.59 & 3.25 & 7.83 & 3.04 & 2.63 & 3.76 & 2.99 & 2.53 & 4.14 & 3.32 \\
\hline $\mathrm{Eu}$ & 0.98 & 1.20 & 2.57 & 1.06 & 0.97 & 1.29 & 1.05 & 0.87 & 1.40 & 1.28 \\
\hline Gd & 3.66 & 4.75 & 8.70 & 3.46 & 3.59 & 4.05 & 3.44 & 2.69 & 4.86 & 4.66 \\
\hline $\mathrm{Tb}$ & 0.71 & 0.86 & 1.39 & 0.63 & 0.70 & 0.74 & 0.67 & 0.57 & 0.82 & 1.03 \\
\hline $\mathrm{Tm}$ & 0.43 & 0.54 & 0.61 & 0.35 & 0.48 & 0.47 & 0.44 & 0.30 & 0.44 & 0.66 \\
\hline $\mathrm{Yb}$ & 2.77 & 3.68 & 3.60 & 2.26 & 2.73 & 2.68 & 2.39 & 2.12 & 2.88 & 4.01 \\
\hline $\mathrm{Lu}$ & 0.45 & 0.57 & 0.55 & 0.38 & 0.45 & 0.43 & 0.38 & 0.32 & 0.47 & 0.62 \\
\hline Th & 0.14 & 0.16 & 1.85 & 0.67 & 0.24 & 1.12 & 0.75 & 0.56 & 1.92 & 0.31 \\
\hline Ta & 0.09 & 0.10 & 1.86 & 0.52 & 0.14 & 0.90 & 0.58 & 0.44 & 1.39 & 0.18 \\
\hline $\mathrm{Hf}$ & 1.80 & 2.44 & 5.36 & 2.05 & 1.87 & 2.53 & 1.99 & 1.57 & 2.68 & 2.34 \\
\hline \multicolumn{11}{|l|}{ Element ratios } \\
\hline $\mathrm{Ce}_{\mathrm{N}} / \mathrm{Yb}_{\mathrm{N}}$ & 0.59 & 0.58 & 3.3 & 1.71 & 0.79 & 2.17 & 1.73 & 1.52 & 2.7 & 0.56 \\
\hline $\mathrm{La}_{\mathrm{N}} / \mathrm{Sm}_{\mathrm{N}}$ & 0.44 & 0.47 & 1.58 & 1.23 & 0.63 & 1.75 & 1.37 & 1.28 & 2.11 & 0.57 \\
\hline $\mathrm{Tb}_{\mathrm{N}} / \mathrm{Yb}_{\mathrm{N}}$ & 1.09 & 0.99 & 1.63 & 1.17 & 1.09 & 1.17 & 1.18 & 1.14 & 1.21 & 1.09 \\
\hline $\mathrm{La} / \mathrm{Ta}$ & 20.4 & 24.4 & 10.8 & 11.6 & 19.1 & 11.8 & 11.4 & 11.9 & 10.1 & 16.9 \\
\hline $\mathrm{Th} / \mathrm{Ta}$ & 1.56 & 1.60 & 0.99 & 1.29 & 1.71 & 1.24 & 1.29 & 1.27 & 1.38 & 1.72 \\
\hline
\end{tabular}

Note: $\mathrm{Ce}_{\mathrm{N}} / \mathrm{Yb}_{\mathrm{N}}, \mathrm{La}_{\mathrm{N}} / \mathrm{Sm}_{\mathrm{N}}$, and $\mathrm{Tb}_{\mathrm{N}} / \mathrm{Yb}_{\mathrm{N}}$ express the ratios of chondrite-normalized (Nakamura, 1974) rare earth elements. 
Table 6. Analyses of olivine microphenocrysts from Leg 82 holes.

\begin{tabular}{|c|c|c|c|c|c|c|c|c|c|}
\hline \multirow{2}{*}{$\begin{array}{l}\text { Hole } \\
\text { Core-Section } \\
\text { (interval in cm) } \\
\text { Chemical group }\end{array}$} & \multirow{2}{*}{$\begin{array}{c}556 \\
4-2 \\
65-68 \\
\text { II }\end{array}$} & \multicolumn{3}{|c|}{558} & \multirow{2}{*}{ 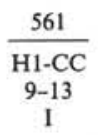 } & \multicolumn{2}{|c|}{562} & \multirow{2}{*}{$\begin{array}{c}563 \\
24-4 \\
0-7\end{array}$} & \multirow{2}{*}{ 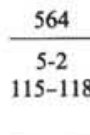 } \\
\hline & & $\begin{array}{c}27-3 \\
92-95 \\
1\end{array}$ & $\begin{array}{c}30-3 \\
12-14 \\
\text { III }\end{array}$ & $\begin{array}{c}35-1 \\
120-122 \\
\text { IV }\end{array}$ & & $\begin{array}{c}3-2 \\
14-143 \\
1\end{array}$ & $\begin{array}{c}8-1 \\
68-71 \\
\text { II }\end{array}$ & & \\
\hline \multicolumn{10}{|c|}{ Major elements (wt.\%) } \\
\hline $\begin{array}{l}\mathrm{SiO}_{2} \\
\mathrm{FeO} \\
\mathrm{MnO}\end{array}$ & $\begin{array}{l}39.29 \\
15.61\end{array}$ & $\begin{array}{l}39.69 \\
14.70\end{array}$ & $\begin{array}{l}39.86 \\
13.97\end{array}$ & $\begin{array}{l}40.26 \\
12.28\end{array}$ & $\begin{array}{l}40.05 \\
12.92\end{array}$ & $\begin{array}{r}38.93 \\
17.72 \\
0.34\end{array}$ & $\begin{array}{r}39.35 \\
14.98 \\
0.26\end{array}$ & $\begin{array}{l}39.80 \\
14.35\end{array}$ & $\begin{array}{l}39.14 \\
16.43\end{array}$ \\
\hline $\begin{array}{l}\mathrm{MgO} \\
\mathrm{CaO}\end{array}$ & $\begin{array}{r}44.50 \\
0.33\end{array}$ & $\begin{array}{r}45.14 \\
0.26\end{array}$ & $\begin{array}{r}45.67 \\
0.36\end{array}$ & $\begin{array}{r}47.36 \\
0.30\end{array}$ & $\begin{array}{r}46.70 \\
0.34\end{array}$ & $\begin{array}{r}42.01 \\
0.40\end{array}$ & $\begin{array}{r}44.97 \\
0.32\end{array}$ & $\begin{array}{r}45.52 \\
0.35\end{array}$ & $\begin{array}{r}43.73 \\
0.33\end{array}$ \\
\hline Total & 99.73 & 99.79 & 99.86 & 100.20 & 100.01 & 99.40 & 99.88 & 100.02 & 99.63 \\
\hline \multicolumn{10}{|c|}{ Formula on the basis of 4 oxygens } \\
\hline $\mathrm{Si}$ & 0.993 & 0.997 & 0.997 & 0.996 & 0.996 & 0.998 & 0.991 & 0.996 & 0.994 \\
\hline $\begin{array}{l}\mathrm{Fe} \\
\mathrm{Mn}\end{array}$ & 0.330 & 0.309 & 0.292 & 0.254 & 0.269 & $\begin{array}{l}0.380 \\
0.007\end{array}$ & $\begin{array}{l}0.316 \\
0.006\end{array}$ & 0.300 & 0.349 \\
\hline $\mathrm{Mg}$ & 1.676 & 1.690 & 1.703 & 1.746 & 1.731 & 1.605 & 1.688 & 1.698 & 1.655 \\
\hline $\mathrm{Ca}$ & 0.009 & 0.007 & 0.010 & 0.008 & 0.009 & 0.011 & 0.009 & 0.009 & 0.009 \\
\hline Fo & 84 & 85 & 85 & 87 & 87 & 81 & 84 & 85 & 83 \\
\hline
\end{tabular}

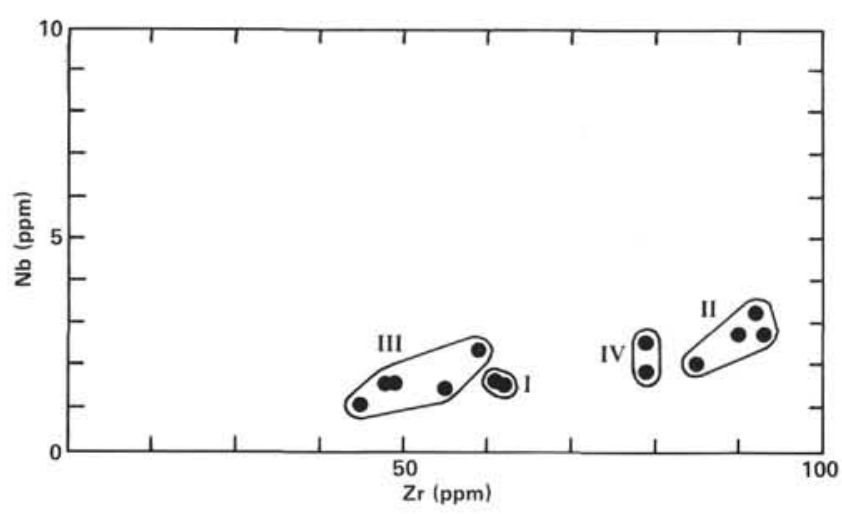

Figure 4. Plot of $\mathrm{Nb}$ versus $\mathrm{Zr}$ for Hole 556 basalts. Roman numerals show chemical groups.

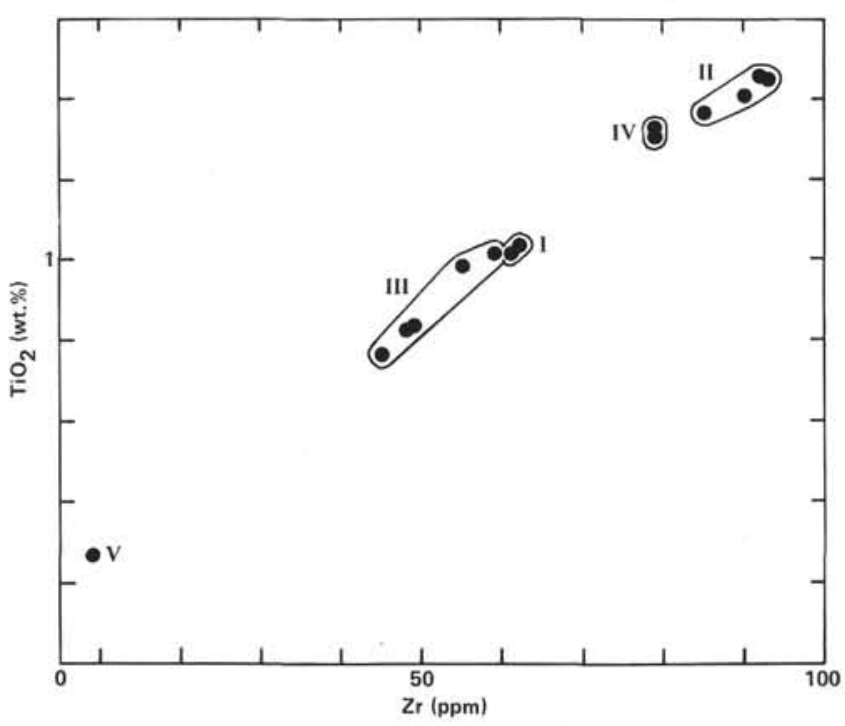

Figure 5. Plot of $\mathrm{TiO}_{2}$ versus $\mathrm{Zr}$ for Hole 556 basalts. Roman numerals show chemical groups.
Table 7. Mixing calculations for the derivation of phyric basalts from aphyric basalts in Chemical Groups III, Hole 556, and II, Hole 562.

\begin{tabular}{|c|c|c|c|c|c|c|c|c|}
\hline $\begin{array}{l}\text { Section containing } \\
\text { phenocryst-enriched } \\
\text { magma (chemical group) }\end{array}$ & $\mathrm{SiO}_{2}$ & $\mathrm{TiO}_{2}$ & $\mathrm{Al}_{2} \mathrm{O}_{3}$ & $\mathrm{FeO}^{*}$ & $\mathrm{MnO}$ & $\mathrm{MgO}$ & $\mathrm{Na}_{2} \mathrm{O}$ & $\mathrm{P}_{2} \mathrm{O}_{5}$ \\
\hline \multicolumn{9}{|l|}{$556-10-2$ (III) } \\
\hline Observed & 49.12 & 0.79 & 17.51 & 7.45 & 0.15 & 7.32 & 2.47 & 0.09 \\
\hline Calculated & 49.04 & 0.81 & 17.62 & 7.65 & 0.12 & 7.32 & 2.58 & 0.07 \\
\hline $\operatorname{Mix}(w t . \%)$ & \multicolumn{8}{|c|}{$556-7.1(80.1)+A_{75}(16.7)+F_{84}(2.4): \Sigma R^{2}=0.0724$} \\
\hline \multicolumn{9}{|l|}{ 562.6-4 (II) } \\
\hline & & & & 8.59 & & 6.76 & 2.16 & 0.11 \\
\hline Calculated & $\begin{array}{l}49.04 \\
\end{array}$ & 1.13 & $\begin{array}{l}18.07 \\
\end{array}$ & 8.51 & 0.14 & 6.98 & 2.34 & 0.11 \\
\hline $\operatorname{Mix}(w t . \%)$ & \multicolumn{8}{|c|}{$562-8-1(93.9)+A_{91}(7.9): \Sigma R^{2}=0.0934$} \\
\hline
\end{tabular}

Note: $\Sigma R^{2}$ is the sum of squares of residuals (obs. concentration-calc. concentration). FeO* is total iron expressed as $\mathrm{FeO} . \mathrm{CaO}$ omitted from the calculation due to calcite contamination. For the least-squares approximations, the method of Bryan et al. (1969) has been used.

pyroxene as $\mathrm{FeO})$ or $58\left(\mathrm{Fe}_{2} \mathrm{O}_{3}\right.$ in clinopyroxene determined by charge balance). This latter composition corresponds to the basalts of Groups II or IV in Hole 556.

\section{SITE 557}

Site $557\left(38^{\circ} 49.95^{\prime} \mathrm{N} ; 32^{\circ} 33.58^{\prime} \mathrm{W}, 2143 \mathrm{~m}\right.$ water depth) lies on Magnetic Anomaly 5D (18 Ma) on the west flank of the Mid-Atlantic Ridge on the same flow line through the Azores Triple Junction as Site 556. A single hole was drilled and only $3 \mathrm{~m}$ of basement (encountered at $460.5 \mathrm{~m}$ sub-bottom depth) was cored before enforced abandonment of the hole. A single lithologic unit composing one chemical group was recognized by the shipboard party, consisting of very fresh aphyric basalt.

The aphyric basalt from Hole 557 is medium grained with an intersertal to intergranular texture. Plagioclase $\left(\mathrm{An}_{59}-\mathrm{An}_{48} ;\right.$ Table 1$)$ and clinopyroxene $\left(\mathrm{Wo}_{42} \mathrm{En}_{45} \mathrm{Fs}_{13}\right.$; Table 3) occur in subequal proportions, the clinopyroxene and patches of devitrified glass (15-20 vol.\% with the composition of smectite) filling the interstices in the random network of plagioclase laths, together with equant titanomagnetite $(\sim 10 \mathrm{vol} . \%)$. 
Analyses of two samples from the top and bottom of Core 557-1, Section 1 (557-1-1, 38-41 cm and 557-1-1, 144-147 cm) are given in Table 8. Shipboard analyses indicated the chemical homogeneity of the basalt from this section, although a sample from a pebble in the wash-core is of a slightly different composition (see site chapter, Site 557, this volume). In terms of the normative components Di-Ol-Hy (Fig. 2), Hole 557 basalts are

Table 8. Major and trace element analyses for Hole 557 basalts.

\begin{tabular}{|c|c|c|}
\hline $\begin{array}{l}\text { Core-Section } \\
\text { (interval in cm) } \\
\text { Piece number }\end{array}$ & $\begin{array}{c}1-1 \\
38-41 \\
4\end{array}$ & $\begin{array}{c}1-1 \\
144-147 \\
14\end{array}$ \\
\hline \multicolumn{3}{|c|}{ Major elements (wt.\%) } \\
\hline $\mathrm{SiO}_{2}$ & 47.18 & 46.40 \\
\hline $\mathrm{TiO}_{2}$ & 3.42 & 3.43 \\
\hline $\mathrm{Al}_{2} \mathrm{O}_{3}$ & 12.73 & 12.38 \\
\hline $\mathrm{Fe}_{2} \mathrm{O}_{3}$ & 16.10 & 16.17 \\
\hline $\mathrm{MnO}^{\circ}$ & 0.21 & 0.20 \\
\hline $\mathrm{MgO}$ & 5.04 & 5.11 \\
\hline $\mathrm{CaO}$ & 9.79 & 9.85 \\
\hline $\mathrm{Na}_{2} \mathrm{O}$ & 2.82 & 2.85 \\
\hline $\mathrm{K}_{2} \mathrm{O}$ & 0.55 & 0.48 \\
\hline $\mathrm{P}_{2} \mathrm{O}_{5}$ & 0.33 & 0.34 \\
\hline LOI & 2.28 & 2.45 \\
\hline Total & 100.45 & 99.66 \\
\hline
\end{tabular}

Trace elements (ppm)

$\begin{array}{lrr}\mathrm{Cr} & 32 & 30 \\ \mathrm{Ni} & 36 & 37 \\ \mathrm{~V} & 384 & 384 \\ \mathrm{Zn} & 131 & 130 \\ \mathrm{Ga} & 23 & 24 \\ \mathrm{Rb} & 14 & 10 \\ \mathrm{Sr} & 298 & 304 \\ \mathrm{Ba} & 133 & 123 \\ \mathrm{Zr} & 225 & 218 \\ \mathrm{Nb} & 30 & 28 \\ \mathrm{La} & 21 & 21 \\ \mathrm{Ce} & 52 & 52 \\ \mathrm{Nd} & 30 & 30 \\ \mathrm{Y} & 44 & 44\end{array}$

Selected element ratios

\begin{tabular}{|c|c|c|}
\hline $\mathrm{Mg}$-value & 41.0 & 42.0 \\
\hline $\mathrm{Ti} / \mathrm{Zr}$ & 91.0 & 94.0 \\
\hline $\mathrm{Zr} / \mathrm{Nb}$ & 7.6 & 7.9 \\
\hline $\mathrm{Ce}_{\mathrm{N}} / \mathrm{Y}_{\mathrm{N}}$ & 2.7 & 2.7 \\
\hline $\mathrm{Zr} / \mathrm{Ce}$ & 4.5 & 4.3 \\
\hline $\mathrm{Zr} / \mathrm{Y}$ & 5.3 & 5.1 \\
\hline
\end{tabular}

CIPW norms

\begin{tabular}{lrr} 
Or & 3.3 & 2.9 \\
$\mathrm{Ab}$ & 24.3 & 24.8 \\
$\mathrm{An}$ & 20.9 & 20.1 \\
$\mathrm{Di}$ & 22.0 & 23.2 \\
$\mathrm{Hy}$ & 15.4 & 12.6 \\
$\mathrm{Ol}$ & 2.5 & 4.5 \\
$\mathrm{Mt}$ & 2.8 & 2.9 \\
$\mathrm{II}$ & 6.6 & 6.7 \\
$\mathrm{Ap}$ & 0.8 & 0.8 \\
\hline
\end{tabular}

Note: LOI is loss on ignition. Total iron is expressed as $\mathrm{Fe}_{2} \mathrm{O}_{3}$. CIPW norms and $\mathrm{Mg}$-values (100 Mg/ $\left.\left[\mathrm{Mg}+\mathrm{Fe}^{2+}\right]\right)$ are calculated using an assumed $\mathrm{Fe}_{2} \mathrm{O}_{3} / \mathrm{FeO}$ ratio of 0.15 . $\mathrm{Ce}_{\mathrm{N}} / \mathrm{Y}_{\mathrm{N}}$ expresses the chondrite-normalized ratio of $\mathrm{Ce}$ to $\mathrm{Y}$. not dissimilar to the basalts from Chemical Units I and II of Hole 556, containing only small amounts of normative Ol. However, the basalt from Hole 557 is chemically highly evolved, having high contents of incompatible trace elements (e.g., Zr, Nb, Ba, LREE; Table 8; Fig. 6), total iron (as $\mathrm{Fe}_{2} \mathrm{O}_{3}$ ), and a low $\mathrm{Mg}$-value (Table 8); it is clearly a ferrobasalt. In marked contrast to the basalts from Hole 556, the ferrobasalt from Hole 557 is enriched in the more-incompatible elements, as indicated by the high $\mathrm{Ce}_{\mathrm{N}} / \mathrm{Y}_{\mathrm{N}}(2.7)$ and low $\mathrm{Zr} / \mathrm{Nb}(7.6-7.9) \mathrm{ra}-$ tios (Table 8; Fig. 6). The major and trace element chemistry is comparable to that of other ferrobasalts from the North Atlantic (Chemical Unit I, Hole 407; Wood, Tarney, et al., 1979), ferrobasalts from East Iceland (Wood, 1978), as well as ferrobasalts from the southwest

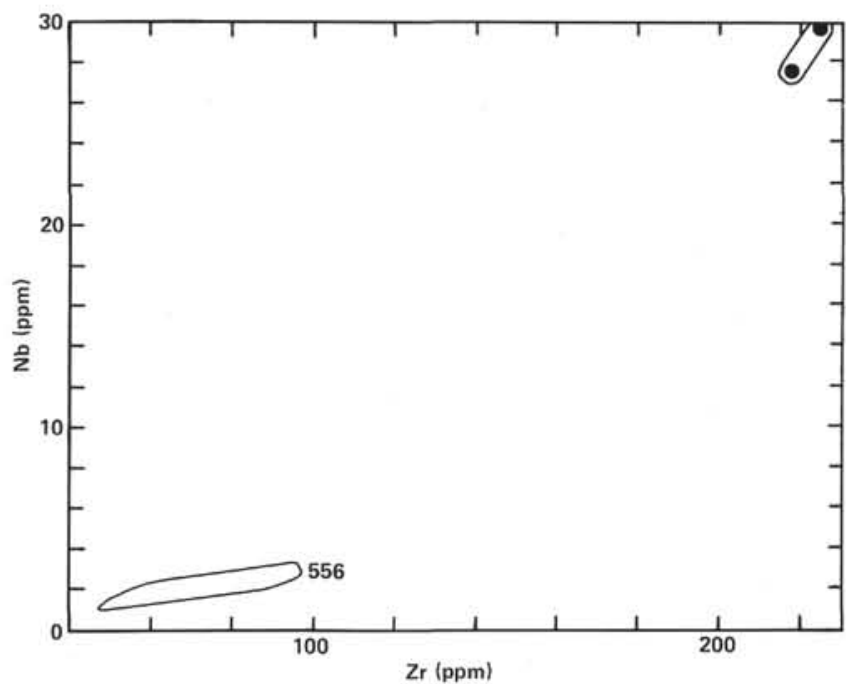

Figure 6. Plot of $\mathrm{Nb}$ versus $\mathrm{Zr}$ for Hole 557 basalts. Also shown is the field for Hole 556 basalts from Figure 4.

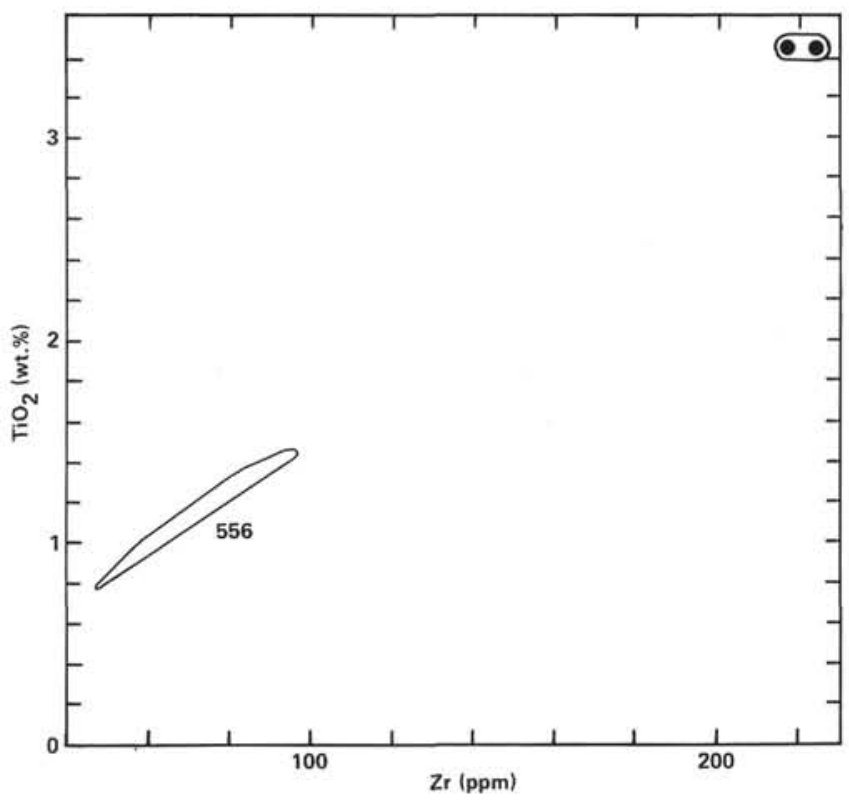

Figure 7. Plot of $\mathrm{TiO}_{2}$ versus $\mathrm{Zr}$ for Hole 557 basalts. Also shown is the field for Hole 556 basalts from Figure 5 . 
Indian Ocean (Speiss Ridge; Le Roex et al., 1982) and the East Pacific (Galapagos spreading center, Clague et al., 1976). In each of these cases, the ferrobasalts have been modeled as the products of advanced degrees $(70-80 \%)$ of fractional crystallization of primary liquid compositions, the crystal extract being dominated by subequal proportions of plagioclase and augite with minor olivine and titanomagnetite (Clague et al., 1976; Wood, Tarney, et al., 1979: Le Roex et al., 1982). Such a model is equally applicable to the ferrobasalts of Hole 557. However, although Hole 557 ferrobasalts may be the product of large degrees of crystal fractionation, ratios between more-incompatible and less-incompatible elements will not have been greatly modified. Adopting $\mathrm{K}_{\mathrm{d}}$ data from Le Roex and others $(1981 ; 1982)$ for $\mathrm{Zr}$, $\mathrm{Nb}, \mathrm{Ce}$, and $\mathrm{Y}$ and assuming that a primary basalt undergoes $70 \%$ Rayleigh fractionation of equal proportions of plagioclase and augite, the $\mathrm{Zr} / \mathrm{Nb}$ and $\mathrm{Ce}_{\mathrm{N}} / \mathrm{Y}_{\mathrm{N}}$ ratios of the residual liquid change by only $10 \%$ (decrease) and $28 \%$ (increase), respectively, over those of the parent liquid. Thus the parent liquid would have $\mathrm{Zr}$ / $\mathrm{Nb} \sim 8.6$ and $\mathrm{Ce}_{\mathrm{N}} / \mathrm{Y}_{\mathrm{N}} \sim 2.1$.

REE data are given in Table 5 and plotted in Figure 3. This sample has a high $\mathrm{Ce}_{\mathrm{N}} / \mathrm{Yb}_{\mathrm{N}}$ ratio (3.3) with approximately 60 times the chondrite levels of the LREE. A significant Eu anomaly is absent. The marked contrast with the LREE-depleted basalts of Hole 556 (Fig. 3) is apparent.

\section{SITE 558}

Site $558\left(37^{\circ} 46.20^{\prime} \mathrm{N} ; 37^{\circ} 20.61^{\prime} \mathrm{W}, 3754 \mathrm{~m}\right.$ water depth) lies between Magnetic Anomalies 12 and 13 (35 Ma old) on the west flank of the Mid-Atlantic Ridge. It is approximately 30 miles south of the Pico Fracture Zone on a flow line passing through the FAMOUS area, the four sites drilled by Leg 37, and the three sites drilled by Leg 49 . Two holes were drilled, of which only the first (Hole 558) penetrated basement. In Hole 558, $153 \mathrm{~m}$ of basement (encountered at $408 \mathrm{~m}$ sub-bottom depth) were cored before the hole was abandoned. A total of 11 lithologic units comprising 6 chemical groups were identified by the shipboard party. The upper $110 \mathrm{~m}$ of basement consists of aphyric pillow basalts and pillow basalt breccias. Beneath this, $43 \mathrm{~m}$ of mylonitized gabbro was cored to the bottom of the hole.

Petrographically the basalts from Chemical Groups I, IV, and V are all similar, composed of euhedral olivine microphenocrysts (5-10 vol.\%, composition $\mathrm{Fo}_{85}$ Group I, $\mathrm{Fo}_{87}$ Group IV; Table 6) that are generally altered to clay (completely so in the case of Group V). The groundmass comprises $30-40$ vol. \% swallowtail plagioclase laths (up to $0.5 \mathrm{~mm}$ ), approximately $20 \mathrm{vol} . \%$ granular clinopyroxene, and 30-40 vol. \% mesostasis. Chemical Group II basalts have only approximately 2 vol. $\%$ olivine microphenocrysts and contain subequal (30-40 vol.\%) proportions of swallowtail plagioclase laths and granular clinopyroxene and 20-30 vol.\% devitrified glass. Chemical Group II basalts have an unusually high proportion (up to $20 \mathrm{vol} . \%$ ) of olivine micro-phenocrysts $\left(\mathrm{Fo}_{85}\right.$, Table 6), with groundmass plagioclase (25-30 vol. \%) subordinate to clinopyroxene (30-40 vol. $\%)$ and quite a high proportion ( $\sim 10 \mathrm{vol} . \%)$ of skeletal magnetite.

Group I comprises the massive aphyric basalt of Lithologic Unit 3. Only one sample was analyzed from this group (558-27-3, 92-95 cm) and the data are presented in Table 9. This sample has a moderate amount of normative $\mathrm{Ol}$, but a rather high $\mathrm{Hy} / \mathrm{Di}$ ratio, especially compared to the remainder of Hole 558 basalts (Fig. 8). This sample has a high $\mathrm{Mg}$-value (67, Table 9) and $\mathrm{Ni}$ and $\mathrm{Cr}$ contents (Table 9; Figs. 9, 10) and has the characteristics of near primitive mantle melts in the FAMOUS area suggested by Fujii and Bougault (1983). In terms of incompatible trace elements, this group is enriched in the more-incompatible elements; $\mathrm{Zr} / \mathrm{Nb}$ ratios are low $\left(\sim 10\right.$; Table 9) and $\mathrm{Ce}_{\mathrm{N}} / \mathrm{Y}_{\mathrm{N}}$ is high $(\sim 1.3$; Table 9). It also has a chemistry typical of E-type MORB, confirmed by the REE data (Table 5, Fig. 11) that demonstrates the LREE-enriched nature of the basalt of this group $\left(\mathrm{Ce}_{\mathrm{N}} /\right.$ $\mathrm{Yb}_{\mathrm{N}}=1.7, \mathrm{La}_{\mathrm{N}} / \mathrm{Sm}_{\mathrm{N}}=1.2$; Table 5).

Group II comprises basalts from Lithologic Unit 4. Four samples were analyzed from this group, and the data are given in Table 9. Normatively these basalts have low Ol and straddle the Di-Hy join (Fig. 8). In marked contrast to the basalt of Group I, this group displays depletion in the more-incompatible elements. $\mathrm{Zr} / \mathrm{Nb}$ ratios are high (20-27, Table 9, Fig. 12); $\mathrm{Ce}_{\mathrm{N}} / \mathrm{Y}_{\mathrm{N}}$ ratios are low (0.7-0.9; Table 9, Fig. 13) and comparable to the depleted basalts of Hole 556, although they have more $\mathrm{Cr}$ and a lower Mg-value than the basalts of Group I, Hole 556, to which they have the greatest similarity in terms of incompatible element abundances. The basalts of this group are, however, less depleted in the more-incompatible elements than any of the Hole 556 basalts.

The N-type MORB nature of this group is indicated by the REE data (Table 5, Fig. 11). $\mathrm{Ce}_{\mathrm{N}} / \mathrm{Yb}_{\mathrm{N}}$ and $\mathrm{La}_{\mathrm{N}} /$ $\mathrm{Sm}_{\mathrm{N}}$ ratios are low (0.8 and 0.6 , respectively), but the ratios of these elements are higher than in the N-MORB of Hole 556.

Group III comprises basalts from Lithological Units 5,6 , and part of 7. Eight samples were analyzed from this group (from Cores 558-29 to 558-34), and the data are presented in Table 9. The shipboard party divided this group into two subgroups, A and B, a division that is followed in this report. We have analyzed four basalts from each subgroup, and the chemical distinction is clear in terms of the normative mineralogy. Group IIIA basalts have low normative $\mathrm{Ol}$ and straddle the Di-Hy join, but contain relatively more Hy than Group II basalts (Fig. 8). Compared to Group IIIA basalts, Group IIIB basalts are more Ol-rich and have a slightly higher $\mathrm{Di} / \mathrm{Hy}$ ratio (Fig. 8). The coherence of these basalts as one chemical group is indicated by the similar $\mathrm{Zr} / \mathrm{Nb}$, $\mathrm{Ce} / \mathrm{Y}, \mathrm{Zr} / \mathrm{P}$, and $\mathrm{Zr} / \mathrm{Y}$ ratios (Figs. 12-15). However, the distinction of subgroups is clear from the differences in abundance levels of particularly $\mathrm{P}, \mathrm{Ti}, \mathrm{Zr}, \mathrm{Nb}$, and the REE (Group IIIA is enriched in these elements) (Table 9; Figs. 12-16). The low $\mathrm{Zr} / \mathrm{Nb}$ ratios (6-6.4; Table 9) and high $\mathrm{Ce}_{\mathrm{N}} / \mathrm{Y}_{\mathrm{N}}$ ratios (1.7-2.1; Table 9) indicate enrichment of more incompatible elements in this group, the degree of enrichment being greater than that displayed by Group I (Figs. 12-17). It may be that the 
Table 9. Major and trace element analyses for Hole 558 basalts.

\begin{tabular}{|c|c|c|c|c|c|c|c|c|c|c|c|c|c|c|c|c|c|c|c|c|c|c|c|c|}
\hline \multirow{2}{*}{$\begin{array}{l}\text { Chemical group } \\
\text { Core-Section } \\
\text { (interval in cm) } \\
\text { Piece number }\end{array}$} & \multirow{2}{*}{ 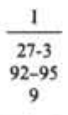 } & \multicolumn{4}{|c|}{ II } & \multicolumn{4}{|c|}{ IIIA } & \multicolumn{4}{|c|}{ IIIB } & \multicolumn{3}{|c|}{ IVA } & \multicolumn{3}{|c|}{ IVB } & \multicolumn{5}{|c|}{$\mathrm{v}$} \\
\hline & & $\begin{array}{c}28-1 \\
38-41 \\
3\end{array}$ & $\begin{array}{c}28-1 \\
79-81 \\
8\end{array}$ & $\begin{array}{c}28-2 \\
52-55 \\
7\end{array}$ & $\begin{array}{c}28-3 \\
36-38 \\
4\end{array}$ & $\begin{array}{c}29-1 \\
99-101 \\
7 \mathrm{~b}\end{array}$ & $\begin{array}{c}30-3 \\
12-14 \\
2\end{array}$ & $\begin{array}{c}31-1 \\
86-89 \\
5 d\end{array}$ & $\begin{array}{c}32-1 \\
115-117 \\
8 \mathrm{~b}\end{array}$ & $\begin{array}{c}32-3 \\
38-40 \\
4 b\end{array}$ & $\begin{array}{c}32-5 \\
88-90 \\
3 \mathrm{~b}\end{array}$ & $\begin{array}{c}33-3 \\
135-138 \\
9 d\end{array}$ & $\begin{array}{c}34-1 \\
63-65 \\
3 f\end{array}$ & $\begin{array}{c}35-1 \\
120-122 \\
11 a\end{array}$ & $\begin{array}{c}35-2 \\
112-114 \\
6 \mathrm{~b}\end{array}$ & $\begin{array}{c}35-3 \\
89-91 \\
7 \mathrm{~b}\end{array}$ & $\begin{array}{c}35-4 \\
102-104 \\
10\end{array}$ & $\begin{array}{c}36-1 \\
82-84 \\
6 c\end{array}$ & $\begin{array}{c}36-2 \\
100-102 \\
5 d\end{array}$ & $\begin{array}{c}37-1 \\
143-148 \\
196\end{array}$ & $\begin{array}{c}38-1 \\
104-108 \\
14 a\end{array}$ & $\begin{array}{c}39-1 \\
55-57 \\
5 \mathrm{c}\end{array}$ & $\begin{array}{c}39-2 \\
69-71 \\
3 c\end{array}$ & $\begin{array}{c}39-4 \\
98-100 \\
4 c\end{array}$ \\
\hline \multicolumn{25}{|c|}{ Major elements (wt.\%) } \\
\hline $\mathrm{SiO}_{2}$ & 49.58 & 49.86 & 49.49 & 49.60 & 50.20 & 49.58 & 49.21 & 50.10 & 48.41 & 48.36 & 49.08 & 48.47 & 48.39 & 49.13 & 48.50 & 48.45 & 48.99 & 48.65 & 49.04 & 48.34 & 47.34 & 48.19 & 48.21 & 47.96 \\
\hline & 1.22 & 1.08 & 1.08 & 1.09 & $\begin{array}{r}1.08 \\
1.05\end{array}$ & 1.37 & 1.38 & $\begin{array}{r}1.38 \\
1.74\end{array}$ & $\begin{array}{r}1.38 \\
1.78\end{array}$ & 1.26 & 1.27 & 1.26 & 1.26 & 1.18 & 1.20 & 1.20 & 1.22 & 1.22 & 1.23 & 0.93 & 0.95 & 0.96 & 0.94 & 0.94 \\
\hline $\mathrm{Al}_{2} \mathrm{O}_{3}$ & 14.43 & 15.01 & 15.14 & 15.14 & 15. & 14.63 & 14.65 & 14.75 & 14.78 & 14.82 & 14.86 & 14.69 & 15.12 & 14.56 & 14.88 & 14.82 & 14.77 & 14.73 & 14.92 & 15.26 & 15.82 & 15.85 & 15.59 & 15.57 \\
\hline & 10.41 & 10.10 & 9. & 10.42 & & 9.40 & 9.94 & 9. & & 9.52 & 9. & 9.64 & 9. & 9.65 & 10.02 & 10.0 & 9 & 9.82 & & 9. & 9.76 & 9.32 & 9.44 & 9.66 \\
\hline & 0. & 0. & 0. & 0. & 0 & 0.13 & & 0. & & & & & & & & & & & & 0 & & & & 15 \\
\hline & 9.38 & $\begin{array}{r}8.01 \\
11.85\end{array}$ & 7.51 & 7.91 & & & 7.90 & & & 8.73 & & & & & & & & & & & & & & 47 \\
\hline $\mathrm{CaO}$ & $\begin{array}{r}10.35 \\
2.27\end{array}$ & $\begin{array}{r}11.85 \\
2.15\end{array}$ & $\begin{array}{r}12.03 \\
2.24\end{array}$ & $\begin{array}{l}12.16 \\
2.15\end{array}$ & $\begin{array}{r}11.76 \\
2.21\end{array}$ & $\begin{array}{l}10.97 \\
2.39\end{array}$ & $\begin{array}{r}10.94 \\
2.35\end{array}$ & $\begin{array}{l}11.11 \\
2.36\end{array}$ & $\begin{array}{l}11.30 \\
2.35\end{array}$ & $\begin{array}{r}11.33 \\
2.32\end{array}$ & $\begin{array}{l}11.24 \\
2.26\end{array}$ & $\begin{array}{ll}11.23 \\
2.23\end{array}$ & $\begin{array}{l}11.61 \\
2.36\end{array}$ & $\begin{array}{r}11.31 \\
2.17\end{array}$ & 11.71 & 11.62 & 11.17 & 11.40 & 11.23 & 11.33 & 11.47 & 11.67 & 11.38 & 11.90 \\
\hline $\begin{array}{l}\mathrm{N}_{2} \mathrm{O} \\
\mathrm{K}_{2} \mathrm{O}\end{array}$ & $\begin{array}{l}2.27 \\
0.39\end{array}$ & 2.15 & $\begin{array}{l}2.24 \\
0.29\end{array}$ & $\begin{array}{l}2.15 \\
0.25\end{array}$ & 2.21 & 2.3 & $\begin{array}{l}2.35 \\
0.49\end{array} \mathrm{~V} \mathrm{x}$ & $\begin{array}{l}2.36 \\
0.29\end{array}$ & $\begin{array}{l}2.3 .35 \\
0.35\end{array}$ & $\begin{array}{l}2.32 \\
0.32\end{array}$ & 2.26 & $\begin{array}{l}2.23 \\
0.36\end{array}$ & 2. & $\begin{array}{l}2.17 \\
0.33\end{array}$ & $\begin{array}{l}2.26 \\
0.35\end{array}$ & 2.1. & 2.2 .3 & $\begin{array}{l}2.19 \\
0.38\end{array}$ & 2.3. & $\begin{array}{l}2.0 \\
0.2\end{array}$ & $\begin{array}{l}2.07 \\
0.29\end{array}$ & 2.14 & 2.09 & 2.14 \\
\hline $\begin{array}{l}\mathrm{K}_{2} \mathrm{O} \\
\mathrm{P}_{2} \mathrm{O}\end{array}$ & 0.13 & $\begin{array}{l}0.31 \\
0.11\end{array}$ & $\begin{array}{l}0.29 \\
0.10\end{array}$ & 0.25 & $\begin{array}{l}0.24 \\
0.10\end{array}$ & $\begin{array}{l}0.47 \\
0.19\end{array}$ & $\begin{array}{l}0.49 \\
0.19\end{array}$ & $\begin{array}{l}0.29 \\
0.19\end{array}$ & $\begin{array}{l}0.39 \\
0.20\end{array}$ & $\begin{array}{l}0.32 \\
0.18\end{array}$ & 0.41 & $\begin{array}{l}0.36 \\
0.17\end{array}$ & $\begin{array}{l}0.36 \\
0.17\end{array}$ & $\begin{array}{l}0.33 \\
0.14\end{array}$ & $\begin{array}{l}0.33 \\
0.16\end{array}$ & $\begin{array}{l}0.32 \\
0.15\end{array}$ & $\begin{array}{l}0.35 \\
0.17\end{array}$ & $\begin{array}{l}0.38 \\
0.17\end{array}$ & $\begin{array}{l}0.39 \\
0.17\end{array}$ & 0.29 & 0.29 & 0.24 & $\begin{array}{l}0.23 \\
0.12\end{array}$ & 0.25 \\
\hline $\begin{array}{l}\mathrm{P}_{2} \mathrm{O}_{3} \\
\mathrm{O} \mathrm{I}\end{array}$ & $\begin{array}{l}0.13 \\
2.11\end{array}$ & $\begin{array}{l}0.11 \\
1.60\end{array}$ & $\begin{array}{l}0.10 \\
2.39\end{array}$ & $\begin{array}{l}0.11 \\
1.49\end{array}$ & $\begin{array}{l}0.10 \\
2.35\end{array}$ & $\begin{array}{l}0.19 \\
3.64\end{array}$ & $\begin{array}{l}0.19 \\
3.14\end{array}$ & $\begin{array}{l}0.19 \\
3.02\end{array}$ & $\begin{array}{l}0.20 \\
3.60\end{array}$ & $\begin{array}{l}0.18 \\
3.56\end{array}$ & $\begin{array}{l}0.17 \\
2.87\end{array}$ & $\begin{array}{l}0.17 \\
3.07\end{array}$ & $\begin{array}{l}0.17 \\
3.88\end{array}$ & $\begin{array}{l}.14 \\
2.40\end{array}$ & $\begin{array}{l}0.16 \\
2.98\end{array}$ & $\begin{array}{l}0.15 \\
2.74\end{array}$ & $\begin{array}{l}0.17 \\
2.62\end{array}$ & $\begin{array}{l}0.17 \\
2.98\end{array}$ & $\begin{array}{l}0.17 \\
2.94\end{array}$ & $\begin{array}{l}0.11 \\
2.23\end{array}$ & $\begin{array}{l}0.13 \\
3.82\end{array}$ & $\begin{array}{l}0.12 \\
3.19\end{array}$ & $\begin{array}{l}0.12 \\
2.70\end{array}$ & $\begin{array}{l}0.12 \\
3.15\end{array}$ \\
\hline Total & 100.42 & 100.23 & 100.27 & 100.48 & 100.09 & 100.55 & 100.33 & 100.14 & 100.14 & 100.54 & 100.32 & 100.26 & 100.36 & 100.18 & 100.52 & 100.41 & 100.44 & 100.09 & 100.51 & 100.33 & 100.39 & 100.28 & 100.17 & 100.31 \\
\hline
\end{tabular}

Trace elements (ppm)

\begin{tabular}{|c|c|c|c|c|c|c|c|c|c|c|c|c|c|c|c|c|c|c|c|c|c|c|c|c|}
\hline $\mathrm{Cr}$ & 544 & 448 & 445 & 462 & 430 & 380 & 383 & 387 & 386 & 412 & 403 & 392 & 420 & 416 & 433 & 431 & 374 & 355 & 353 & 488 & 509 & 513 & 514 & 505 \\
\hline $\mathrm{Ni}$ & 265 & 140 & 136 & 116 & 138 & 170 & 151 & 152 & 156 & 153 & 154 & 155 & 134 & 1 & 168 & 174 & 169 & 166 & 167 & 218 & 23 & 203 & 216 & 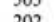 \\
\hline v & 239 & 270 & 268 & 280 & 259 & 282 & 280 & 284 & 286 & 269 & 267 & 258 & 278 & 270 & 280 & 280 & 268 & $\begin{array}{l}200 \\
263\end{array}$ & 264 & 221 & 230 & 234 & $\begin{array}{l}2280 \\
228\end{array}$ & ${ }_{227} 227$ \\
\hline $\mathrm{Zn}$ & 84 & 84 & 82 & 81 & 80 & 82 & 85 & 84 & 85 & 84 & 77 & 79 & 84 & 80 & 83 & 80 & 78 & 81 & 81 & 73 & 73 & 75 & 73 & 74 \\
\hline $\mathrm{Ga}$ & 16 & 15 & 17 & 17 & 16 & 17 & 17 & 17 & 17 & 17 & 16 & 16 & 17 & 16 & 15 & 16 & 16 & 17 & 17 & 14 & 15 & 16 & 16 & 15 \\
\hline $\mathrm{Rb}$ & 7 & 8 & 6 & 5 & 4 & 7 & 9 & 5 & 7 & 6 & 6 & 6 & 5 & 5 & 5 & 6 & 4 & 7 & 7 & 6 & 7 & 4 & 3 & 3 \\
\hline Sr & 137 & 88 & 88 & 91 & 89 & 175 & 169 & 174 & 172 & 177 & 181 & 177 & 182 & 145 & 147 & 148 & 144 & 147 & 144 & 111 & 112 & 113 & 110 & 121 \\
\hline $\mathrm{Ba}$ & 55 & 11 & 9 & 13 & 12 & 57 & 49 & 56 & 48 & 42 & 46 & 41 & 42 & 38 & 36 & 33 & 40 & 42 & 44 & 23 & 18 & 22 & 21 & 21 \\
\hline $\mathrm{Zr}$ & 75 & 66 & ${ }^{64}$ & 63 & 66 & 90 & 89 & 91 & 91 & 78 & 80 & 80 & 79 & 74 & 75 & 76 & 81 & 82 & 81 & 57 & 57. & 61 & 60 & 59 \\
\hline $\mathrm{Nb}$ & $\begin{array}{l}7.8 \\
6\end{array}$ & $<2$ & 2.4 & $<2^{3.2}$ & ${ }_{2}^{2.7}$ & $\begin{array}{l}14.3 \\
10\end{array}$ & $\begin{array}{l}14.0 \\
9\end{array}$ & $\begin{array}{l}14.8 \\
9\end{array}$ & $\begin{array}{l}14.5 \\
10\end{array}$ & ${ }_{9}^{13.0}$ & $\begin{array}{c}13.3 \\
8\end{array}$ & 13.2 & 12.9 & 9.2 & $\begin{array}{l}9.2 \\
6\end{array}$ & 9.8 & ${ }^{10.8}$ & ${ }_{8}^{11.6}$ & 11.5 & 7.2 & 7.3 & $\begin{array}{l}7.7 \\
4\end{array}$ & $\begin{array}{l}7.4 \\
4\end{array}$ & 7.6 \\
\hline $\mathrm{Ce}$ & 13 & 9 & 8 & 10 & 9 & 23 & 24 & 23 & 21 & 22 & 19 & 21 & 19 & $\begin{array}{r}0 \\
16\end{array}$ & $\begin{array}{r}6 \\
16\end{array}$ & 15 & 19 & 19 & 20 & 3 & 12 & $\begin{array}{c}4 \\
12\end{array}$ & ${ }_{13}^{4}$ & 11 \\
\hline $\mathrm{Nd}$ & 9 & 9 & 8 & 8 & 8 & 13 & 13 & 14 & 13 & 12 & 11 & 12 & 11 & 9 & 11 & 9 & ii & II & II & 9 & 8 & 8 & 8 & 8 \\
\hline $\mathbf{y}$ & 24 & 28 & 25 & 27 & 27 & 26 & 25 & 25 & 28 & 24 & 24 & 23 & 23 & 25 & 25 & 25 & 25 & 25 & 26 & 20 & 21 & 21 & 22 & 21 \\
\hline
\end{tabular}

Selected element ratios

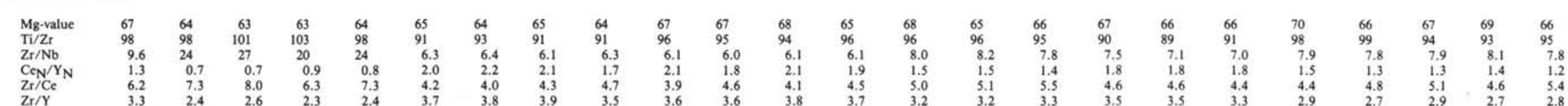

CIPW norms

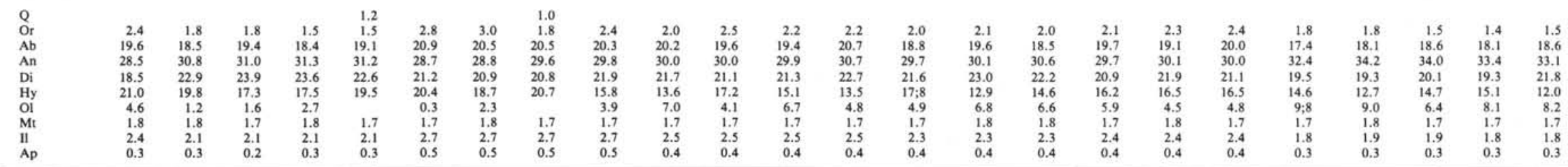

Note: $\mathrm{LOI}$ is loss on ignition. Total iron is expressed as $\mathrm{Fe}_{2} \mathrm{O}_{3}$. ClPW norms and $\mathrm{Mg}$-values $\left(100 \mathrm{Mg} /\left[\mathrm{Mg}+\mathrm{Fe}^{2+}\right]\right)$ are calculated using an assumed $\mathrm{Fe}_{2} \mathrm{O}_{3} / \mathrm{FeO}$ ratio of 0.15 . Ce $\mathrm{C}_{\mathrm{N}} / \mathrm{Y}_{\mathrm{N}}$ expresses the chondrite-normalized ratio of $\mathrm{Ce}$ to $\mathrm{Y}$. 


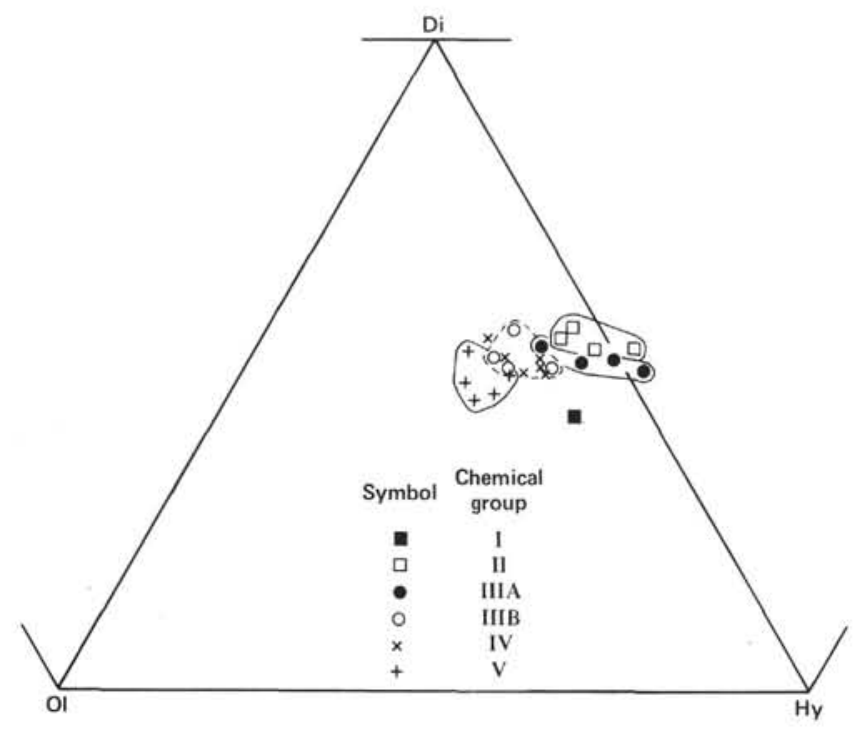

Figure 8. Plot of normative components Ol-Di-Hy for Hole 558 basalts. Norms are calculated using an $\mathrm{Fe}_{2} \mathrm{O}_{3} / \mathrm{FeO}$ ratio of 0.15 .

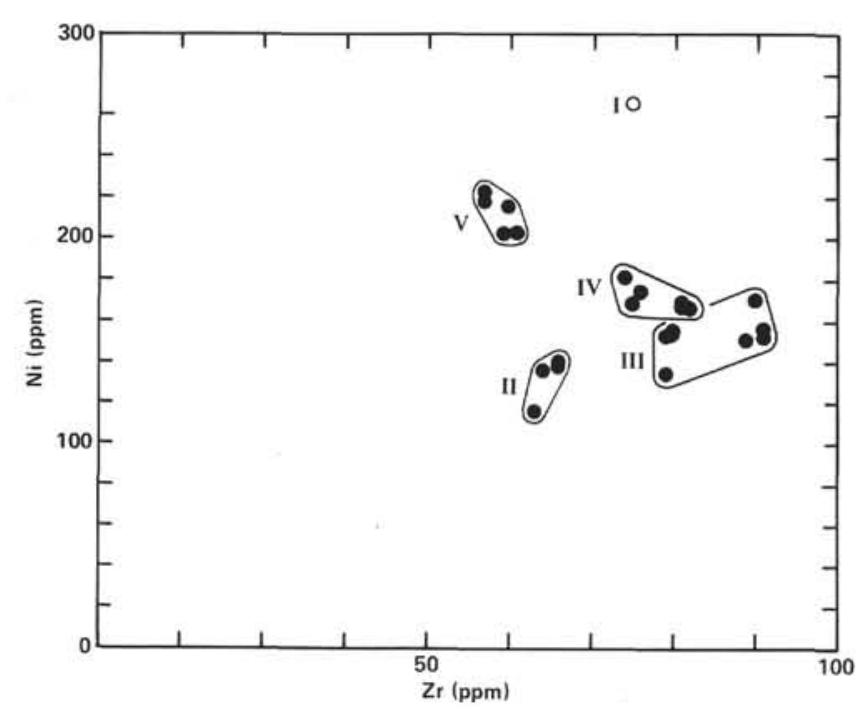

Figure 9. Plot of Ni versus $\mathrm{Zr}$ for Hole 558 basalts. Roman numerals indicate chemical groups.

two subgroups are related by crystal fractionation processes; certainly, ratios such as $\mathrm{Zr} / \mathrm{Nb}$ and $\mathrm{Ce} / \mathrm{Y}$ are not fractionated between the subgroups. However, the most successful least-squares models for the major elements require an olivine-plagioclase-clinopyroxene extract and even then, the sums of squares of residuals are unacceptably high.

REE data for Group IIIA basalt are given in Table 5 and plotted in Figure 11. This chemical group is the most evolved of the Hole 558 E-MORB units, with the highest $\mathrm{Ce}_{\mathrm{N}} / \mathrm{Yb}_{\mathrm{N}}$ (2.2) and $\mathrm{La}_{\mathrm{N}} / \mathrm{Sm}_{\mathrm{N}}$ (1.8) ratios and levels of the REE.

Group IV comprises basalts from the remaining part of Lithologic Unit 7. Six samples were analyzed from this group (from Cores 558-35 and 558-36), and the data are presented in Table 9 . The shipboard party consid-

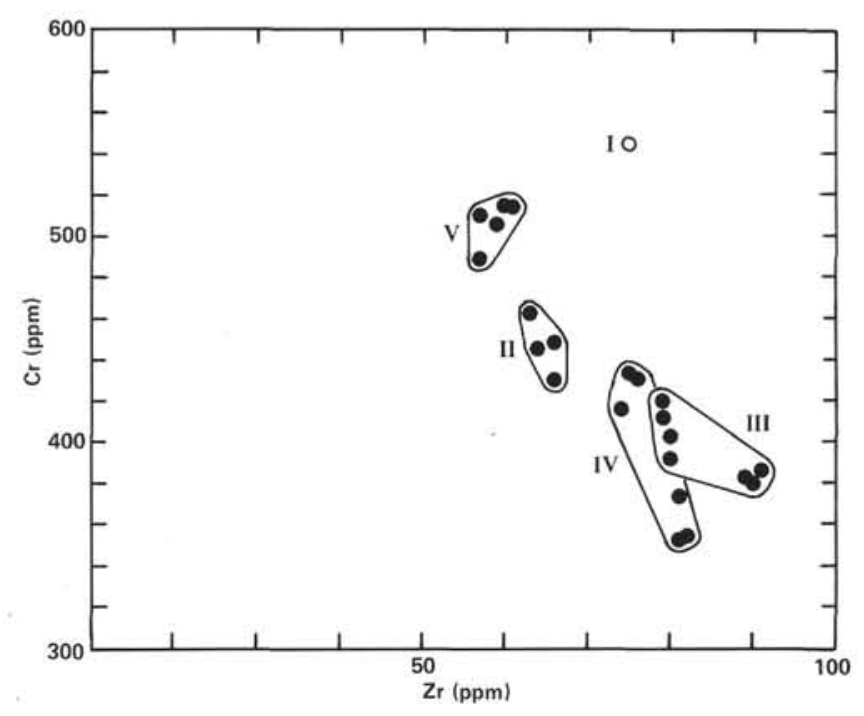

Figure 10. Plot of $\mathrm{Cr}$ versus $\mathrm{Zr}$ for Hole 558 basalts. Roman numerals indicate chemical groups.

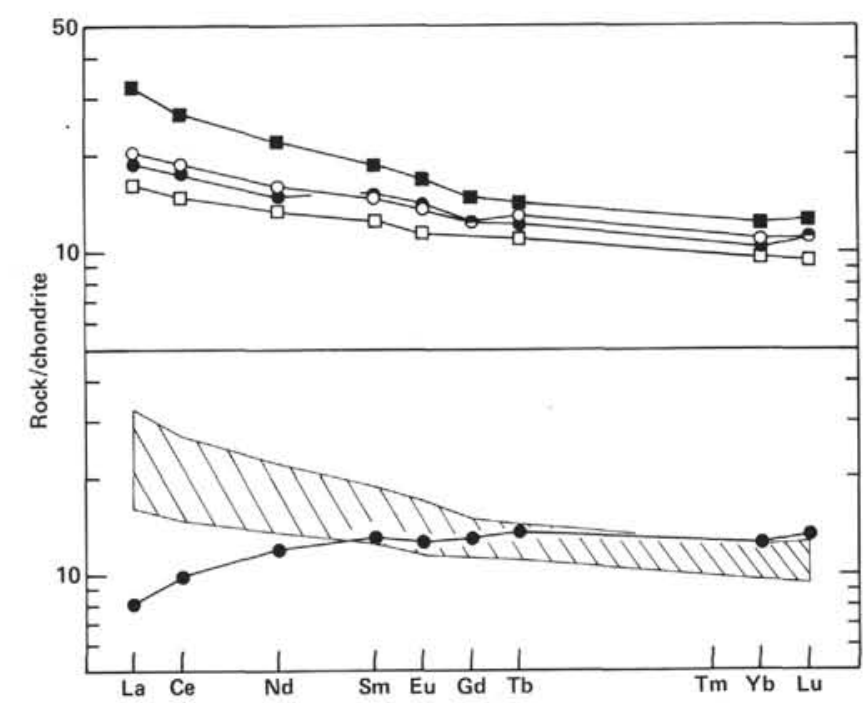

Figure 11. Abundances of the rare earth elements in Hole 558 basalts normalized to the average chondrite values of Nakumara (1974). In top diagram: closed circle = Group I; closed square = Group III; open circle = Group IV; open square $=$ Group V. In bottom diagram: closed circle = Group II. Cross-hatched field is for E-type mid-ocean ridge basalts from top diagram.

ered this to be a homogeneous chemical group. However, evidence from the trace element chemistry indicates that two subgroups may be present. In terms of normative mineralogy, the basalts of this group are indistinguishable from those of Group IIIB, and they behave as a coherent group (Fig. 8). Although there are only small differences in the levels of incompatible elements between the Subgroups IVA and IVB (i.e., $\mathrm{TiO}_{2}$, $1.18-1.20 \%$ in IVA, $1.22-1.23 \%$ in IVB; $\mathrm{Zr}$, 74-76 ppm in IVA, $81-82 \mathrm{ppm}$ in IVB), there are significant differences in incompatible element ratios, particularly $\mathrm{Zr} /$ $\mathrm{Nb}$ (7.8-8.2 in IVA, 7.0-7.5 in IVB) and $\mathrm{Ce}_{\mathrm{N}} / \mathrm{Y}_{\mathrm{N}}$ (1.4-1.5 in IVA, 1.8 in IVB) (Figs. 12, 13). It is apparent 


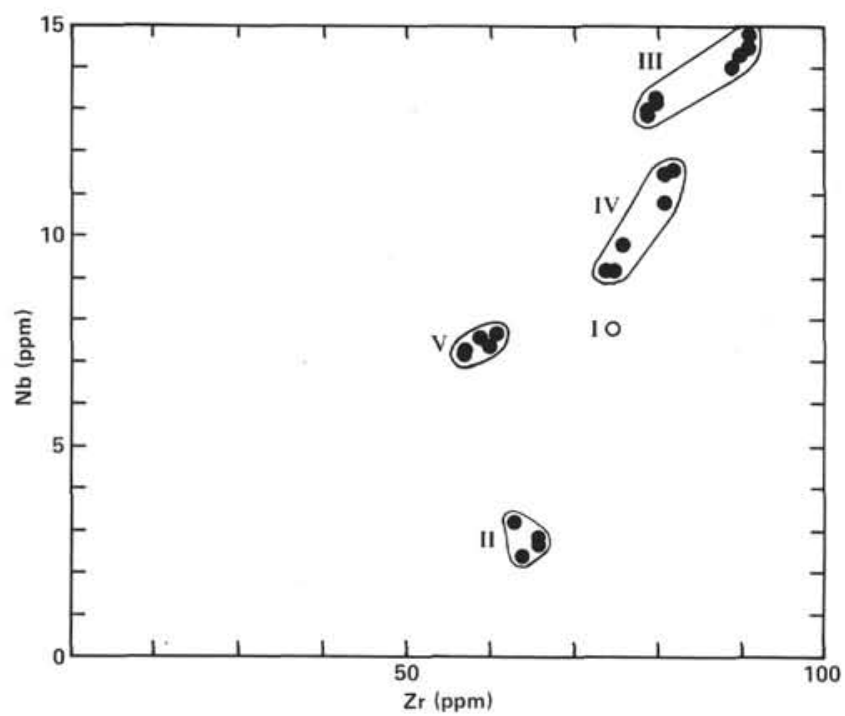

Figure 12. Plot of $\mathrm{Nb}$ versus $\mathrm{Zr}$ for Hole 558 basalts. Roman numerals indicate chemical groups.

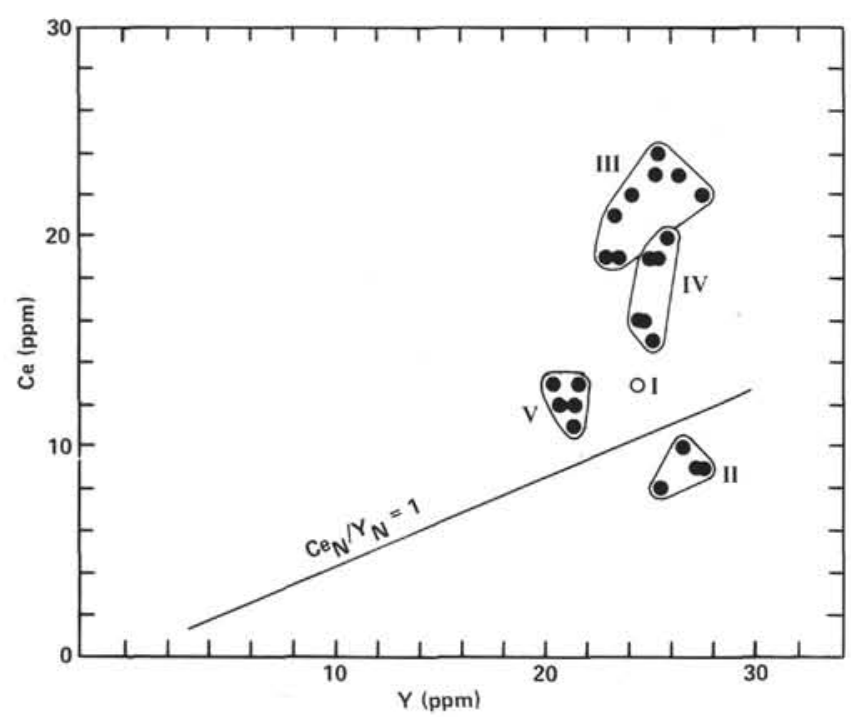

Figure 13. Plot of Ce versus $\mathrm{Y}$ for Hole 558 basalts. Roman numerals indicate chemical groups.

from the values for these ratios that the basalts of this group are enriched in more-incompatible trace elements, although not as enriched as the basalts of Group III (Figs. 12-17). Unlike the chemical variation between the subgroups in Group III, which might be attributable to crystal fractionation processes, the differences in $\mathrm{Zr} / \mathrm{Nb}$ and $\mathrm{Ce} / \mathrm{Y}$ ratios between IVA and IVB basalts prohibit a simple relationship by crystal fractionation, especially as only a small fractionation interval would be involved (namely, a small difference in $\mathrm{Zr}$ abundance between the two subgroups; Table 9, Figs. 12-17). Rather, the differences might be related to degree, or type, or partial melting.

REE data for Group IVA basalt are given in Table 5 and plotted in Figure 11. The levels of REE and degree of LREE enrichment are comparable to the basalt of Chemical Group I.

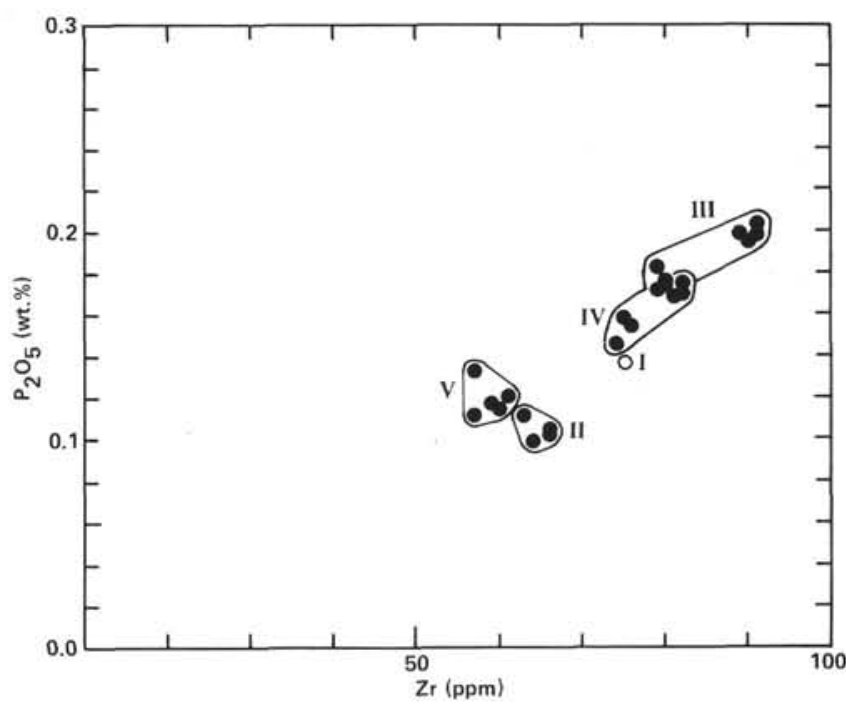

Figure 14. Plot of $\mathrm{P}_{2} \mathrm{O}_{5}$ versus $\mathrm{Zr}$ for Hole 558 basalts. Roman numerals indicate chemical groups.

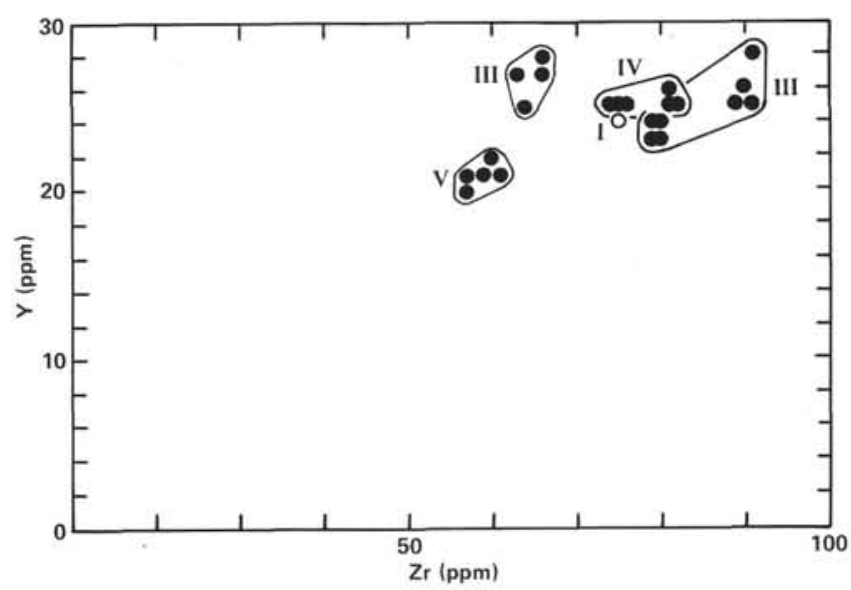

Figure 15. Plot of $\mathrm{Y}$ versus $\mathrm{Zr}$ for Hole 558 basalts. Roman numerals indicate chemical groups.

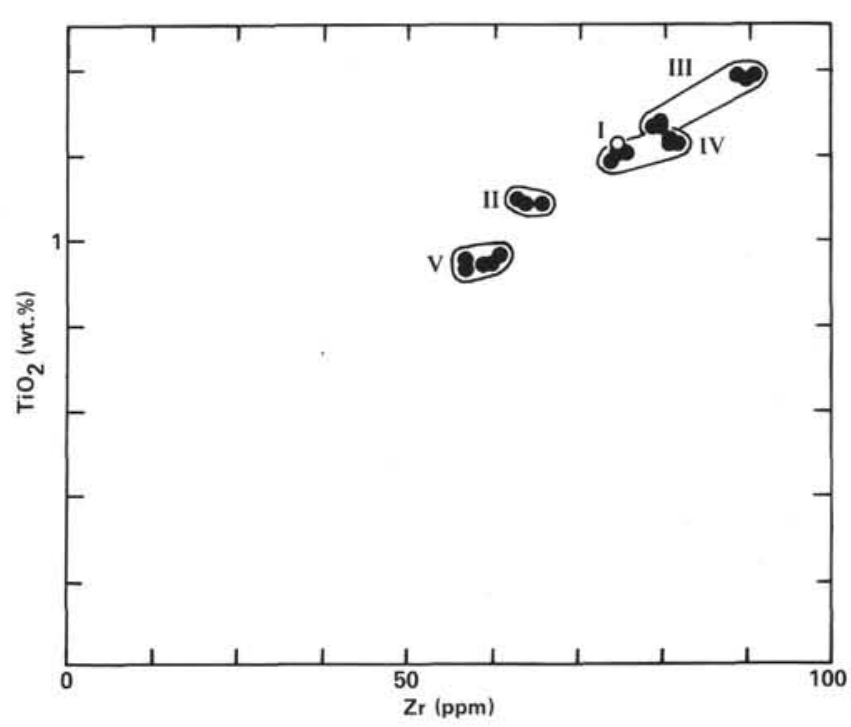

Figure 16. Plot of $\mathrm{TiO}_{2}$ versus $\mathrm{Zr}$ for Hole 558 basalts. Roman numerals indicate chemical groups. 


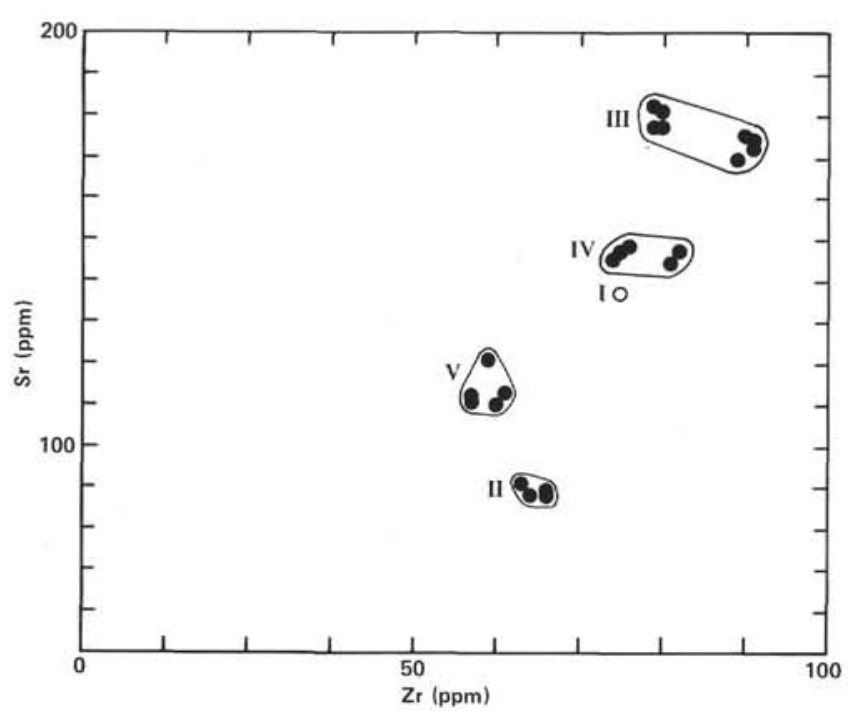

Figure 17. Plot of $\mathrm{Sr}$ versus $\mathrm{Zr}$ for Hole 558 basalts. Roman numerals indicate chemical groups.

Group V comprises basalts from Lithologic Units 8 to 10 . Five samples have been analyzed from this group (from Cores 558-37 through 558-39), and the data are presented in Table 9. Normatively these basalts are more Ol rich than the other basalts from Hole 558 (Fig. 8). They are similar to basalts from Groups I, III, and IV because they are enriched in the more-incompatible (e.g., $\mathrm{Nb}, \mathrm{Ce}$ ) relative to the less-incompatible (e.g., $\mathrm{Zr}, \mathrm{Y}$ ) trace elements $\left(\mathrm{Zr} / \mathrm{Nb} 7.8-8.1 ; \mathrm{Ce}_{\mathrm{N}} / \mathrm{Y}_{\mathrm{N}}\right.$ 1.2-1.5; Table 9, Figs. 12,13); the degree of enrichment is similar to Groups I and IVA for Ce/Y (Fig. 13) and similar to IVB for $\mathrm{Zr}$ / $\mathrm{Nb}$ (Fig. 12). These basalts are significantly less enriched than Group III, however (Figs. 12, 13). Basalts of Group V have the lowest absolute abundances of incompatible trace elements among Hole 558 basalts (Figs. 12-17), high $\mathrm{Mg}$-values (66-70; Table 9), and also high $\mathrm{Ni}$ and $\mathrm{Cr}$ contents (Figs. 9, 10). The slight chemical variation within Group V (Table 9) can be successfully modeled on the basis of a small proportion of olivine fractionation or microphenocryst distribution (Table 10).

The basalts of this group have the lowest levels of REE among the E-MORB units of Hole 558 (Table 5, Fig. 11) with the least LREE enrichment $\left(\mathrm{Ce}_{\mathrm{N}} / \mathrm{Yb}_{\mathrm{N}}=\right.$ 1.5, $\mathrm{La}_{\mathrm{N}} / \mathrm{Sm}_{\mathrm{N}}=1.3$ ).

Table 10. Least squares approximation relating the basalts of Chemical Group V, Hole 558, by olivine fractionation.

\begin{tabular}{|c|c|c|c|c|c|}
\hline & $\begin{array}{c}\text { Derivative } \\
(558-39-1,55-57 \mathrm{~cm})\end{array}$ & Ol & $\begin{array}{c}\text { Parent } \\
(558-37-1,143-148 \mathrm{~cm})\end{array}$ & $\begin{array}{l}\text { Calculated } \\
\text { parent }\end{array}$ & Residuals \\
\hline $\mathrm{SiO}_{2}$ & 49.64 & 40.26 & 49.28 & 49.25 & -0.03 \\
\hline $\mathrm{TiO}_{2}$ & 0.99 & & 0.95 & 0.95 & 0.00 \\
\hline $\mathrm{Al}_{2} \mathrm{O}_{3}$ & 16.33 & & 15.56 & 15.66 & 0.10 \\
\hline $\mathrm{FeO} \cdot$ & 8.64 & 12.28 & 8.87 & 8.79 & -0.08 \\
\hline $\mathrm{MnO}$ & 0.16 & & 0.15 & 0.15 & 0.00 \\
\hline $\mathrm{MgO}$ & 8.69 & 47.36 & 10.22 & 10.27 & 0.05 \\
\hline $\mathrm{CaO}$ & 12.02 & 0.30 & 11.55 & 11.54 & -0.01 \\
\hline $\mathrm{Na}_{2} \mathrm{O}$ & 2.20 & & 2.05 & 2.11 & 0.06 \\
\hline $\mathrm{P}_{2} \mathrm{O}_{5}$ & 0.13 & & 0.12 & 0.12 & 20.00 \\
\hline Mix & 95.9 & 4.1 & & & $\Sigma R^{2}=0.0239$ \\
\hline
\end{tabular}

Note: $\Sigma \mathrm{R}^{2}$ is the sum of the squares of residuals (calculated parent - parent). FeO* is total iron expressed as FeO. For the least-squares approximations, the method of Bryan et al. (1969) has been used.

\section{SITE 559}

Site $559\left(35^{\circ} 07.45^{\prime} \mathrm{N} ; 40^{\circ} 55.00^{\prime} \mathrm{W}, 3754 \mathrm{~m}\right.$ water depth) lies between Magnetic Anomalies 12 and 13 ( $35 \mathrm{Ma}$ old) on the west flank of the Mid-Atlantic Ridge and is approximately midway between the Oceanographer and Hayes fracture zones. A single hole was drilled and $63 \mathrm{~m}$ of basement (encountered at $238 \mathrm{~m}$ sub-bottom depth) were cored before the hole was abandoned. A single lithologic unit comprising one chemical group (consisting of variably, but quite heavily altered, aphyric pillow basalts) was identified.

The aphyric basalts from this hole contain subequal amounts (35-40 vol. \%) of plagioclase and clinopyroxene. The plagioclase occurs as randomly oriented swallowtail laths, and the clinopyroxene as relatively large prismatic grains, parallel aggregates of smaller prisms, sheaves, or branching aggregates. Olivine $(\sim 5 \mathrm{vol} . \%)$ is altered to clay and zeolite as is interstitial glass $(\sim 25$ vol.\%). A microprobe study of the mineral chemistry of basalts from this hole was not made.

Analyses of seven samples from Hole 559 are presented in Table 11. Shipboard analyses of basalts from this hole stressed the significance of chemical changes associated with alteration (site chapter, Site 559, this volume). Extensive alteration was found to produce pronounced depletion in $\mathrm{SiO}_{2}$ and $\mathrm{MgO}$ (and thus a lowering of the $\mathrm{Mg}$-value) and pronounced enrichment of $\mathrm{MnO}, \mathrm{K}_{2} \mathrm{O}$, $\mathrm{P}_{2} \mathrm{O}_{5}, \mathrm{Sr}$, and $\mathrm{V}$. Of the other elements analyzed on board, the major elements $\mathrm{TiO}_{2}, \mathrm{Al}_{2} \mathrm{O}_{3}, \mathrm{Fe}_{2} \mathrm{O}_{3}$, and $\mathrm{CaO}$ and the trace elements $\mathrm{Zr}, \mathrm{Nb}$, and $\mathrm{Y}$ were not significantly affected by even extreme degrees of alteration. These observations are largely in accord with previous studies of the chemical effects of low-temperature basalt-seawater interaction (Hart, 1970; Hart et al., 1974; Thompson and Humphris, 1977). However, the mobility of $\mathbf{P}$ is not generally recognized, although it has been noted by Marsh et al. (1980) and Weaver and others (1983). The shipboard study indicates that fresh basalts from Hole 559 have an Mg-value of $59, \mathrm{~K}_{2} \mathrm{O} \sim 0.4 \%$, $\mathrm{P}_{2} \mathrm{O}_{5} \sim 0.19 \%$, and $\mathrm{Sr} \sim 169 \mathrm{ppm}$. Of the analyzed samples from this hole, all have rather high weight losses upon ignition $(\sim 2.9 \%$, commonly $4 \%$; Table 10$)$, but only the Sample $559-1-2,118-120 \mathrm{~cm}$ (Table 11) has a chemistry indicative of heavy alteration. In addition to the elements identified as mobile in the shipboard study, the trace elements $\mathrm{Ni}$ and $\mathrm{Zn}$ appear to be respectively depleted and enriched in this altered sample, and there is some suggestion that the LREE La and Ce may be enriched over the average abundance in the other samples (Table 11). This again is largely in accord with previous studies of low-temperature basalt alteration.

Hole 559 basalts display some scatter on a plot of the normative components Di-Ol-Hy (Fig. 18), which is largely due to alteration that causes a decrease in the proportion of $\mathrm{Hy}$ and an increase in the proportion of $\mathrm{Ol}$ relative to Di. The fresher basalts have moderate amounts of normative $\mathrm{Ol}$ and are similar to the basalts of Chemical Groups IIIB and IV in Hole 558. In terms of trace element chemistry, Hole 559 basalts are enriched in the 
Table 11. Major and trace element analyses for Hole 559 basalts.

\begin{tabular}{lccccccc}
\hline Core-Section & $1-2$ & $2-2$ & $4-1$ & $5-1$ & $6-2$ & $7-2$ & $8-1$ \\
(interval in cm) & $118-120$ & $18-20$ & $118-121$ & $38-40$ & $12-14$ & $3-6$ & $18-20$ \\
Piece number & $11 \mathrm{a}$ & $1 \mathrm{a}$ & $9 \mathrm{a}$ & $3 \mathrm{a}$ & $1 \mathrm{a}$ & $1 \mathrm{a}$ & $1 \mathrm{a}$ \\
\hline
\end{tabular}

Major elements (wt. \%)

$\begin{array}{lrrrrrrr}\mathrm{SiO}_{2} & 46.40 & 47.30 & 47.59 & 47.72 & 48.14 & 47.23 & 48.00 \\ \mathrm{TiO}_{2} & 1.46 & 1.46 & 1.45 & 1.44 & 1.46 & 1.45 & 1.46 \\ \mathrm{Al}_{2} \mathrm{O}_{3} & 15.36 & 15.48 & 14.82 & 14.88 & 15.11 & 14.38 & 14.79 \\ \mathrm{Fe}_{2} \mathrm{O}_{3} & 10.98 & 10.77 & 10.34 & 10.30 & 9.92 & 10.65 & 10.34 \\ \mathrm{MnO} & 0.15 & 0.16 & 0.13 & 0.13 & 0.13 & 0.15 & 0.14 \\ \mathrm{MgO} & 6.50 & 7.16 & 7.37 & 6.99 & 7.20 & 8.05 & 7.22 \\ \mathrm{CaO} & 11.38 & 12.14 & 11.14 & 11.11 & 11.12 & 11.03 & 10.89 \\ \mathrm{Na}_{2} \mathrm{O} & 2.68 & 2.49 & 2.65 & 2.58 & 2.55 & 2.58 & 2.50 \\ \mathrm{~K}_{2} \mathrm{O} & 0.48 & 0.42 & 0.38 & 0.39 & 0.39 & 0.47 & 0.41 \\ \mathrm{P}_{2} \mathrm{O}_{5} & 0.23 & 0.20 & 0.19 & 0.19 & 0.20 & 0.18 & 0.19 \\ \text { LOI } & 4.61 & 2.93 & 4.29 & 4.38 & 4.21 & 3.53 & 4.23 \\ \text { Total } & 100.23 & 100.51 & 100.35 & 100.11 & 100.43 & 99.70 & 100.17\end{array}$

Trace elements (ppm)

$\begin{array}{lrrrrrrr}\mathrm{Cr} & 299 & 306 & 290 & 295 & 306 & 290 & 281 \\ \mathrm{Ni} & 90 & 127 & 130 & 121 & 161 & 134 & 117 \\ \mathrm{~V} & 328 & 306 & 291 & 298 & 301 & 289 & 291 \\ \mathrm{Zn} & 118 & 88 & 86 & 85 & 85 & 84 & 87 \\ \mathrm{Ga} & 18 & 18 & 18 & 17 & 17 & 16 & 17 \\ \mathrm{Rb} & 8 & 7 & 7 & 7 & 7 & 9 & 8 \\ \mathrm{Sr} & 171 & 173 & 164 & 168 & 169 & 164 & 171 \\ \mathrm{Ba} & 44 & 53 & 42 & 40 & 39 & 49 & 48 \\ \mathrm{Zr} & 102 & 103 & 101 & 100 & 102 & 100 & 103 \\ \mathrm{Nb} & 14.5 & 14.7 & 14.6 & 14.1 & 14.9 & 14.6 & 16.1 \\ \mathrm{La} & 10 & 9 & 9 & 9 & 9 & 8 & 9 \\ \mathrm{Ce} & 24 & 20 & 24 & 21 & 21 & 21 & 21 \\ \mathrm{Nd} & 13 & 13 & 13 & 13 & 13 & 12 & 12 \\ \mathrm{Y} & 31 & 31 & 31 & 30 & 31 & 30 & 31\end{array}$

Selected element ratios

$\begin{array}{lccccccc}\mathrm{Mg} \text {-value } & 57 & 60 & 62 & 60 & 62 & 63 & 61 \\ \mathrm{Ti} / \mathrm{Zr} & 86 & 85 & 86 & 86 & 86 & 87 & 85 \\ \mathrm{Zr} / \mathrm{Nb} & 7.0 & 7.0 & 6.9 & 7.1 & 6.8 & 6.8 & 6.4 \\ \mathrm{Ce} N / \mathrm{Y}_{\mathrm{N}} & 1.8 & 1.5 & 1.8 & 1.6 & 1.6 & 1.6 & 1.6 \\ \mathrm{Zr} / \mathrm{Ce} & 4.6 & 5.6 & 4.5 & 5.1 & 5.2 & 5.1 & 5.3 \\ \mathrm{Zr} / \mathrm{Y} & 3.5 & 3.6 & 3.5 & 3.6 & 3.5 & 3.6 & 3.6\end{array}$

CIPW norms

\begin{tabular}{lrrrrrrr} 
Or & 3.0 & 2.5 & 2.4 & 2.4 & 2.4 & 2.9 & 2.5 \\
$\mathrm{Ab}$ & 23.7 & 21.6 & 23.4 & 22.8 & 22.4 & 22.7 & 22.1 \\
$\mathrm{An}$ & 29.8 & 30.6 & 28.5 & 29.1 & 29.7 & 27.3 & 29.1 \\
$\mathrm{Di}$ & 22.7 & 24.4 & 22.6 & 22.2 & 21.3 & 23.1 & 21.2 \\
$\mathrm{Hy}$ & 5.2 & 2.7 & 7.8 & 11.0 & 12.7 & 5.5 & 14.1 \\
$\mathrm{OI}$ & 10.2 & 12.0 & 9.2 & 6.4 & 5.3 & 12.4 & 4.9 \\
$\mathrm{Mt}$ & 2.0 & 1.9 & 1.9 & 1.9 & 1.8 & 1.9 & 1.9 \\
$\mathrm{II}$ & 2.9 & 2.9 & 2.9 & 2.9 & 2.9 & 2.9 & 2.9 \\
$\mathrm{Ap}$ & 0.6 & 0.5 & 0.5 & 0.4 & 0.5 & 0.4 & 0.5 \\
\hline
\end{tabular}

Note: $\mathrm{LOI}$ is loss on ignition. Total iron is expressed as $\mathrm{Fe}_{2} \mathrm{O}_{3}$. CIPW norms and $\mathrm{Mg}$-values $\left(100 \mathrm{Mg} /\left[\mathrm{Mg}+\mathrm{Fe}^{2+}\right]\right)$ are calculated using an assumed $\mathrm{Fe}_{2} \mathrm{O}_{3} / \mathrm{FeO}$ ratio of 0.15 . $\mathrm{Ce}_{\mathrm{N}} / \mathrm{Y}_{\mathrm{N}}$ expresses the chondrite-normalized ratio of $\mathrm{Ce}$ to $\mathrm{Y}$.

more-incompatible (compared to less-incompatible) elements, with a low $\mathrm{Zr} / \mathrm{Nb}$ ratio $(\sim 7$; Table 11$)$ and a high $\mathrm{Ce}_{\mathrm{N}} / \mathrm{Y}_{\mathrm{N}}$ ratio $(\sim 1.6$; Table 11$)$. These ratios are most comparable to those in basalts from Chemical Group IVA and IVB, Hole 558 (Fig. 10). However, the $\mathrm{Ti} / \mathrm{Zr}$ ratio $(\sim 86$; Table 11$)$ is rather low and less than the value for this ratio in any of the chemical groups from Hole 558 (Fig. 19). Additionally, the low Mg-value $(\sim 61)$, as well as the $\mathrm{Cr}(\sim 300 \mathrm{ppm})$ and $\mathrm{Ni}(\sim 130$ ppm) abundances, do not approximate those expected in primary liquids; the Hole 559 basalts must have undergone significant crystal fractionation. In these terms, they are more evolved than any of the Hole 558 basalts, as also indicated by the greater absolute abundances of $\mathrm{Zr}, \mathrm{Nb}$, and $\mathrm{TiO}_{2}$ (Figs. 19, 20) in the Hole 559 basalts.

\section{SITE 560}

Site $560\left(34^{\circ} 43.33^{\prime} \mathrm{N} ; 38^{\circ} 50.56^{\prime} \mathrm{W}, 3443 \mathrm{~m}\right.$ water depth) lies on Magnetic Anomaly 5D (18 Ma old) on the

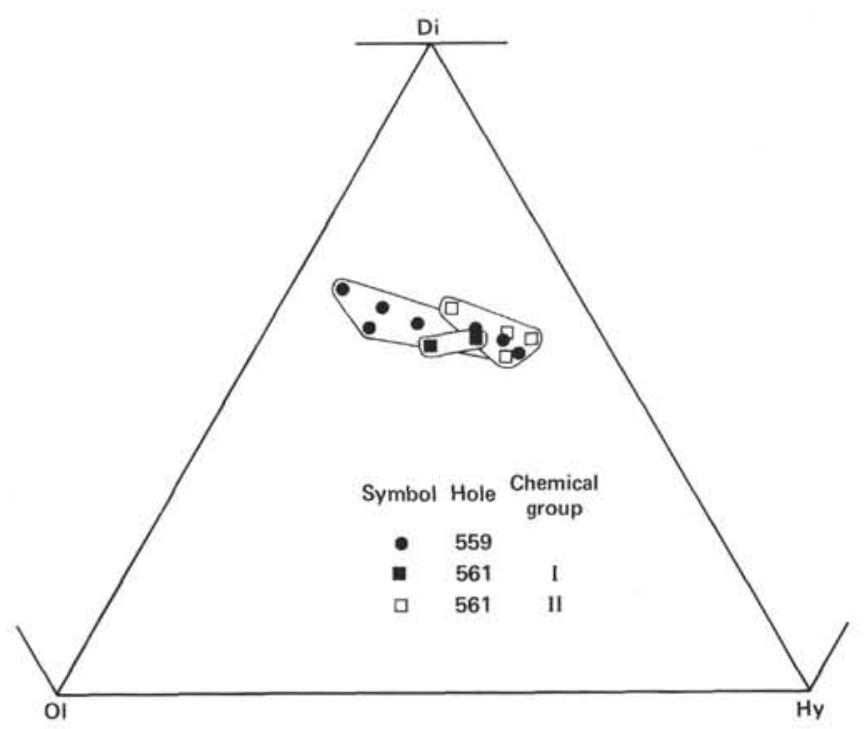

Figure 18. Plot of normative components Ol-Di-Hy for basalts from Holes 559 and 561 . Norms are calculated using an $\mathrm{Fe}_{2} \mathrm{O}_{3} / \mathrm{FeO}$ ratio of 0.15 .

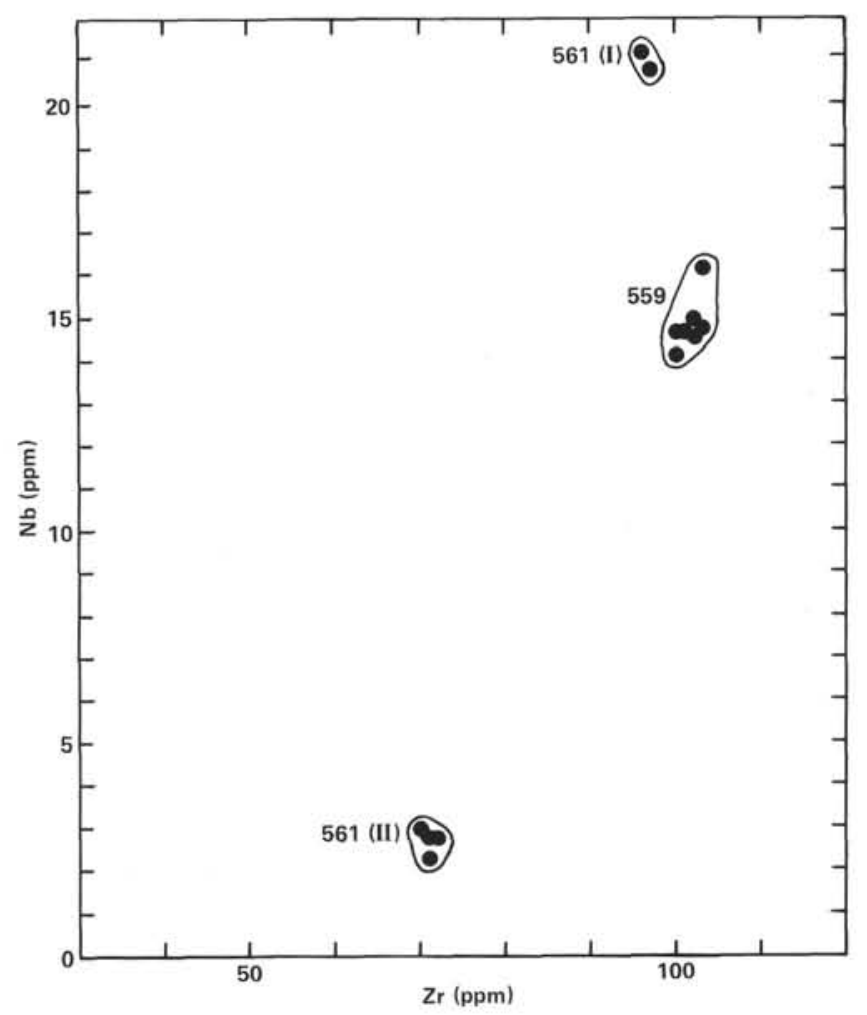

Figure 19. Plot of $\mathrm{Nb}$ versus $\mathrm{Zr}$ for basalts from Holes 559 and 561 . Roman numerals indicate chemical groups.

west flank of the Mid-Atlantic Ridge and is midway between the Oceanographer and Hayes fracture zones on a flow line passing through Site 559. A single hole was drilled at this site, and $47.5 \mathrm{~m}$ of basement (encountered at $374.5 \mathrm{~m}$ sub-bottom depth) were cored before the hole was abandoned. Only mylonitized gabbro breccia, with two short intervals of limestone and limestone-basalt breccia, was recovered from the basement in Hole 


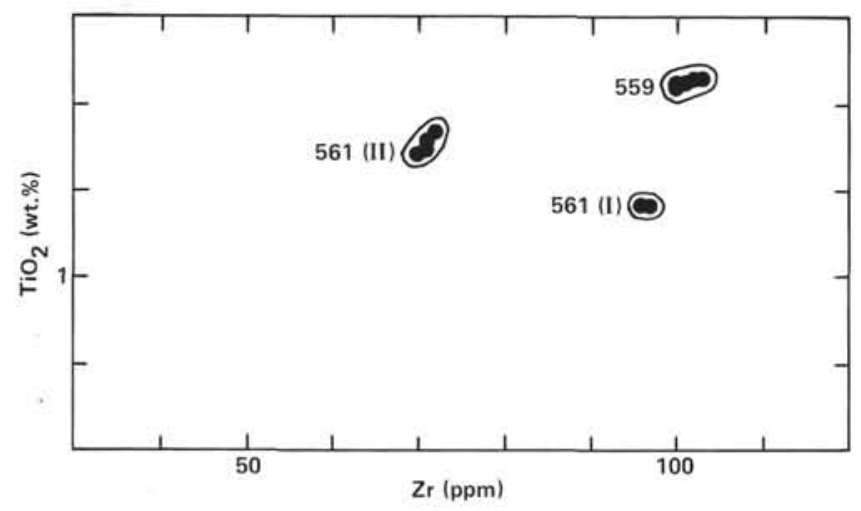

Figure 20. Plot of $\mathrm{TiO}_{2}$ versus $\mathrm{Zr}$ for basalts from Holes 559 and 561 . Roman numerals indicate chemical groups.

560. The basalt clasts from the limestone-basalt breccia are strongly zeolitized.

Because of the extremely limited recovery and the heavily altered nature of the basalt in Hole 560, no sample was taken. Indeed, only one sample was analyzed on board (site chapter, Site 560, this volume), and the major element chemistry appears to be controlled by the strong zeolitization. However, assuming that the relative abundances of the trace elements $\mathrm{Zr}, \mathrm{Nb}$, and $\mathrm{Y}$ have not been modified by zeolitization, original $\mathrm{Zr} / \mathrm{Nb}$ and $\mathrm{Zr} / \mathrm{Y}$ ratios of 11.8 and 2.5 , respectively, are indicated for this sample, suggesting considerably less enrichment of more-incompatible (compared to less-incompatible) elements than in Hole 559 basalts.

\section{SITE 561}

Site $561\left(34^{\circ} 47.10^{\prime} \mathrm{N} ; 39^{\circ} 01.70^{\prime} \mathrm{W}, 3459 \mathrm{~m}\right.$ water depth) lies on Magnetic Anomaly 5E (19 Ma old) on the west flank of the Mid-Atlantic Ridge 10 miles to the northwest of Site 560 and close to the flow line passing through Site 559. We needed to drill at another site in this area because of the failure to recover significant basaltic basement at Site 560 . A single hole was drilled at Site 561 and $15 \mathrm{~m}$ of basement (encountered at $411.5 \mathrm{~m}$ sub-bottom depth) were cored before bit failure. The shipboard party identified three lithologic units comprising two chemical groups, which consisted of basalt-limestone breccia and two units of aphyric pillow basalt.

Group I basalts compose Lithologic Unit 1 . The basalts of this group are aphyric, containing only small amounts $(\sim 2-3$ vol. $\%)$ of rather magnesian olivine microphenocrysts $\left(\mathrm{Fo}_{87}\right.$; Table 6$)$. The ground mass contains subequal $(\sim 35-40 \mathrm{vol} . \%)$ proportions of elongate (up to $1.5 \mathrm{~mm}$ ) hollow plagioclase laths with interstitial granular clinopyroxene. The remainder of the groundmass consists largely of altered mesostasis.

Two samples were analyzed from this group (from the wash-core and the upper part of Core 561-1), and the analyses are given in Table 12. Normatively these basalts have moderate amounts of olivine and plot within the field defined by Hole 559 basalts on the Ol-Di-Hy diagram (Fig. 18). The two samples analyzed from this group are very similar chemically (Table 12 ), with the notable exception of $\mathrm{Sr}$ and $\mathrm{Ba}$, which are enriched by factors of 2 and 3, respectively, in the sample from Core 561-1.
Table 12. Major and trace element analyses for Hole 561 basalts.

\begin{tabular}{|c|c|c|c|c|c|c|}
\hline \multirow{4}{*}{$\begin{array}{l}\text { Chemical group } \\
\text { Core-Section } \\
\text { (interval in cm) } \\
\text { Piece number }\end{array}$} & \multicolumn{2}{|c|}{ I } & \multicolumn{4}{|c|}{ II } \\
\hline & $\mathrm{H} 1-\mathrm{CC}$ & $1-1$ & $1-2$ & $2-1$ & $2-3$ & $3-1$ \\
\hline & $9-13$ & $44-47$ & $22-24$ & $111-116$ & $127-130$ & $138-140$ \\
\hline & 1 & $2 c$ & $2 b$ & $6 c$ & $11 \mathrm{a}$ & $9 j$ \\
\hline \multicolumn{7}{|c|}{ Major elements (wt. \%) } \\
\hline $\mathrm{SiO}_{2}$ & 48.53 & 48.30 & 48.76 & 48.98 & 48.42 & 48.78 \\
\hline $\mathrm{TiO}_{2}$ & 1.16 & 1.16 & 1.34 & 1.32 & 1.30 & 1.29 \\
\hline $\mathrm{Al}_{2} \mathrm{O}_{3}$ & 15.13 & 14.84 & 14.91 & 14.88 & 14.61 & 14.65 \\
\hline $\mathrm{Fe}_{2} \mathrm{O}_{3}$ & 9.47 & 9.67 & 10.93 & 11.43 & 10.89 & 11.54 \\
\hline $\mathrm{MnO}$ & 0.15 & 0.15 & 0.18 & 0.18 & 0.18 & 0.16 \\
\hline $\mathrm{MgO}$ & 8.18 & 9.05 & 8.02 & 7.25 & 7.68 & 7.17 \\
\hline $\mathrm{CaO}$ & 11.72 & 11.76 & 11.49 & 11.56 & 11.93 & 11.45 \\
\hline $\mathrm{Na}_{2} \mathrm{O}$ & 2.36 & 2.30 & 2.41 & 2.38 & 2.46 & 2.30 \\
\hline $\mathrm{K}_{2} \mathrm{O}$ & 0.37 & 0.35 & 0.15 & 0.40 & 0.22 & 0.43 \\
\hline $\mathrm{P}_{2} \mathrm{O}_{5}$ & 0.22 & 0.22 & 0.11 & 0.11 & 0.11 & \\
\hline LOI & 2.79 & 2.63 & 1.53 & 1.84 & 2.08 & 2.12 \\
\hline Total & 100.08 & 100.43 & 99.83 & 100.33 & 99.88 & 100.00 \\
\hline
\end{tabular}

Trace elements (ppm)

$\begin{array}{lrrrrrr}\mathrm{Cr} & 445 & 459 & 260 & 249 & 256 & 256 \\ \mathrm{Ni} & 191 & 197 & 144 & 137 & 135 & 126 \\ \mathrm{~V} & 258 & 264 & 343 & 338 & 336 & 332 \\ \mathrm{Zn} & 81 & 77 & 93 & 96 & 93 & 91 \\ \mathrm{Ga} & 16 & 17 & 19 & 20 & 19 & 19 \\ \mathrm{Rb} & 7 & 5 & 2 & 9 & 5 & 12 \\ \mathrm{Sr} & 221 & 636 & 91 & 91 & 91 & 88 \\ \mathrm{Ba} & 55 & 125 & 12 & 10 & 9 & 10 \\ \mathrm{Zr} & 97 & 96 & 72 & 71 & 71 & 70 \\ \mathrm{Nb} & 21 & 21 & 2.8 & 2.3 & 2.8 & 3.0 \\ \mathrm{La} & 12 & 13 & 3 & 2 & 2 & 2 \\ \mathrm{Ce} & 26 & 27 & 9 & 10 & 10 & 10 \\ \mathrm{Nd} & 13 & 13 & 8 & 8 & 9 & 8 \\ \mathrm{Y} & 27 & 27 & 34 & 35 & 35 & 34\end{array}$

Selected element ratios

$\begin{array}{lcccccc}\mathrm{Mg} \text {-value } & 66 & 68 & 62 & 59 & 61 & 58 \\ \mathrm{Ti} / \mathrm{Zr} & 72 & 72 & 112 & 111 & 110 & 110 \\ \mathrm{Zr} / \mathrm{Nb} & 4.7 & 4.5 & 26 & 31 & 25 & 23 \\ \mathrm{Ce} N / \mathrm{Y}_{\mathrm{N}} & 2.2 & 2.3 & 0.6 & 0.7 & 0.7 & 0.7 \\ \mathrm{Zr} / \mathrm{Ce} & 4.1 & 4.3 & 8.3 & 7.4 & 7.4 & 7.3 \\ \mathrm{Zr} / \mathrm{Y} & 4.0 & 4.3 & 2.2 & 2.1 & 2.1 & 2.1\end{array}$

CIPW norms

\begin{tabular}{lrrrrrr} 
Or & 2.3 & 2.1 & 0.9 & 2.4 & 1.4 & 2.6 \\
$\mathrm{Ab}$ & 20.6 & 19.9 & 20.7 & 20.5 & 21.2 & 19.9 \\
$\mathrm{An}$ & 30.4 & 29.8 & 30.0 & 29.2 & 28.8 & 29.0 \\
$\mathrm{Di}$ & 22.6 & 22.9 & 22.2 & 23.2 & 25.3 & 23.2 \\
$\mathrm{Hy}$ & 11.8 & 9.9 & 14.4 & 13.6 & 9.8 & 15.3 \\
$\mathrm{OI}$ & 7.0 & 10.0 & 6.0 & 5.3 & 7.7 & 4.2 \\
$\mathrm{Mt}$ & 1.7 & 1.7 & 1.9 & 2.0 & 1.9 & 2.0 \\
$\mathrm{II}$ & 2.3 & 2.3 & 2.6 & 2.5 & 25 & 2.5 \\
$\mathrm{Ap}$ & 0.5 & 0.5 & 0.3 & 0.3 & 0.3 & 0.3 \\
\hline
\end{tabular}

Note: $\mathrm{LOI}$ is loss on ignition. Total iron is expressed as $\mathrm{Fe}_{2} \mathrm{O}_{3}$. CIPW norms and $\mathrm{Mg}$-values $\left(100 \mathrm{Mg} /\left[\mathrm{Mg}+\mathrm{Fe}^{2+}\right]\right)$ are calculated using an assumed $\mathrm{Fe}_{2} \mathrm{O}_{3} /$ $\mathrm{FeO}$ ratio of $0.15 . \mathrm{Ce}_{\mathrm{N}} / \mathrm{Y}_{\mathrm{N}}$ expresses the chondrite-normalized ratio of $\mathrm{Ce}$ to $\mathrm{Y}$.

The basalts of this group are quite strongly enriched in more-incompatible compared to less-incompatible trace elements, with very low $\mathrm{Zr} / \mathrm{Nb}$ (4.5-4.7; Table 12, Fig. 19) and high $\mathrm{Ce}_{\mathrm{N}} / \mathrm{Y}_{\mathrm{N}}(2.2-2.3$; Table 12) ratios. These basalt are more enriched than any of the E-type MORB of Holes 558 and 559. They are, however, rather primitive; $\mathrm{Mg}$-values are high ( $\sim 67$; Table 12$)$ as are $\mathrm{Cr}$ and $\mathrm{Ni}$ abundances (Table 12). A feature of this group is the low $\mathrm{Ti} / \mathrm{Zr}$ (Table 12, Fig. 20) and high $\mathrm{Zr} / \mathrm{Y}$ (Table 12) ratios, a feature also evident in the E-type MORB of Holes 558 and 559 , but more pronounced in this chemical group.

The REE data (Table 5) for Sample 561-1-1, 44-47 cm demonstrate the strong enrichment in more-incompati- 
ble elements in this group (Fig. 21). The $\mathrm{Ce}_{\mathrm{N}} / \mathrm{Yb}_{\mathrm{N}}$ (2.7) and $\mathrm{La}_{\mathrm{N}} / \mathrm{Sm}_{\mathrm{N}}(2.11)$ ratios are both high and higher than the values for these ratios in Hole 558 E-type MORB. The REE pattern (Fig. 21) appears to be somewhat concave downward.

Group II basalts compose Lithologic Units 2 and 3. The basalts of this group are characterized by the occurrence of variable proportions (2-3 vol. \%) of plagioclaseolivine glomerocrysts ranging in diameter from 1-3 mm and surrounded by a halo of devitrified glass. The plagioclase phenocrysts are $0.5-2 \mathrm{~mm}$ in length, occur either singly or in glomerophyric aggregates with olivine, and are essentially unzoned, having core compositions of $\mathrm{An}_{73}$ and rim compositions of $\mathrm{An}_{71}$ (Table 1). Olivine phenocrysts (occurring in glomerophyric aggregates with plagioclase) and microphenocrysts range from 0.1 to $0.5 \mathrm{~mm}$ in size and are completely altered to brown clay. The groundmass consists of approximately $35 \mathrm{vol} . \%$ random plagioclase laths (composition $\mathrm{An}_{64}$; Table 1) with approximately $45 \mathrm{vol} . \%$ interstitial prismatic to granular clinopyroxene, plus approximately $5 \mathrm{vol} . \%$ magnetite and 10-15 vol. \% devitrified glass.

Four samples were analyzed from this group and the data are given in Table 12. In terms of normative components, the samples from this group generally have less normative $\mathrm{Ol}$ than Group I and are similar to the fresher basalts from Hole 559 (Fig. 18). In marked contrast to the E-type MORB of Group I, the basalts of this group are depleted in more-incompatible trace elements; $\mathrm{Zr}$ / $\mathrm{Nb}$ ratios are high (23-31; Table 12, Fig. 19) and $\mathrm{Ce}_{\mathrm{N}} /$ $\mathrm{Y}_{\mathrm{N}}$ ratios low (0.6-0.7; Table 12); they are similar to the $\mathrm{N}$-type MORB of Holes 556 and 558. The $\mathrm{Cr}$ and $\mathrm{Ni}$ contents and $\mathrm{Mg}$-values are much lower than in Group I basalts (Table 12 ), whereas the $\mathrm{Ti} / \mathrm{Zr}$ ratio is considerably higher (Table 12, Fig. 20).

REE data for this group are given in Table 5 and plotted in Figure 21. The depletion in the LREE $\left(\mathrm{Ce}_{\mathrm{N}} / \mathrm{Yb}_{\mathrm{N}}\right.$ $=0.6, \mathrm{La}_{\mathrm{N}} / \mathrm{Sm}_{\mathrm{N}}=0.6$ ) is similar to that of the Hole $556 \mathrm{~N}$-type MORB.

\section{SITE 562}

Site $562\left(33^{\circ} 08.49^{\prime} \mathrm{N} ; 41^{\circ} 40.76^{\prime} \mathrm{W}, 3172 \mathrm{~m}\right.$ water depth) lies on Magnetic Anomaly 5D (18 Ma old) on the west flank of the Mid-Atlantic Ridge and is approximately 60 miles south of the Hayes Fracture Zone. A

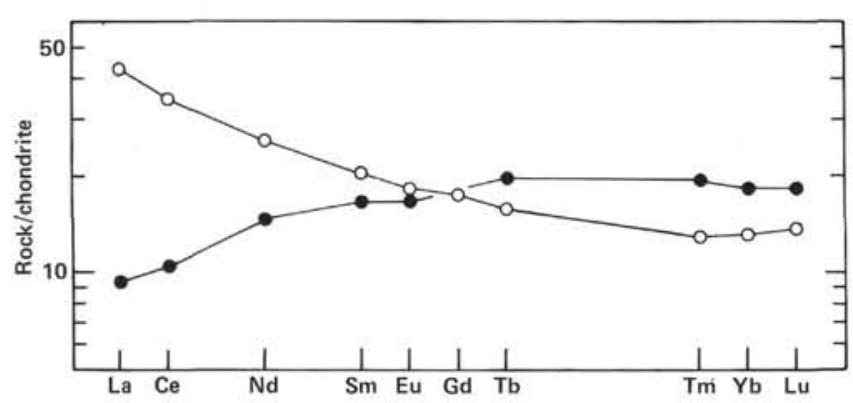

Figure 21. Abundances of the rare earth elements for Hole 561 basalts normalized to the average chondrite values of Nakamura (1974). Open circle $=$ Chemical Group I; closed circle $=$ Chemical Group II. single hole was drilled at this site, and $91 \mathrm{~m}$ of basement (encountered at $240 \mathrm{~m}$ sub-bottom depth) were cored before the hole was abandoned. A single lithologic unit comprising two chemical groups was recognized by the shipboard party, consisting of slightly to moderately plagioclase phyric pillow basalts and massive basalt flows. The degree of alteration is variable.

The basalts from Hole 562 contain approximately 5 vol. $\%$ plagioclase phenocrysts (generally $1-10 \mathrm{~mm}$ in size) that often occur as glomerophyric clusters. The phenocrysts are often subhedral to rounded in outline, are strongly zoned at the margins, and contain inclusions of melt and magnesiochromite. The phenocrysts are zoned from core compositions of $\mathrm{An}_{85}$ to rim compositions of $\mathrm{An}_{67}$ in the Chemical Group I sample (Table 1) and from $A n_{91}$ to $A n_{76}$ in the Chemical Group II sample (Table 1). The melt inclusions have $\mathrm{Mg}$-values of approximately 71 in the Group I sample as opposed to Mg-values of 66 to 67 in the Group II sample. Magnesiochromite inclusions in Group I plagioclase phenocrysts are less magnesian $\left(\mathrm{Mg} /\left[\mathrm{Mg}+\mathrm{Fe}^{2+}\right]=0.67\right)$ and more $\mathrm{Cr}$-rich $(\mathrm{Cr} /[\mathrm{Cr}+\mathrm{Al}]=0.47)$ than the inclusions in Group II plagioclase phenocrysts $(\mathrm{Mg} /[\mathrm{Mg}+$ $\left.\left.\mathrm{Fe}^{2+}\right]=0.77 ; \mathrm{Cr} /[\mathrm{Cr}+\mathrm{Al}]=0.42\right)($ Table 2). Olivine (2-3 vol. \%) occurs as small $(0.1-0.6 \mathrm{~mm})$ rounded anhedral microphenocrysts, which are less magnesian in the Group I ( $\mathrm{Fo}_{81}$; Table 6) as compared to the Group II $\left(\mathrm{Fo}_{84}\right.$; Table 6) sample. The fine-grained groundmass comprises subequal (35-40 vol. \%) proportions of plagioclase and clinopyroxene with approximately $5-10 \mathrm{vol} . \%$ opaques and 10-15 vol.\% mesostasis. The groundmass plagioclase occurs as two distinct generations: as elongate hollow laths (generally $1 \mathrm{~mm}$, but up to $3 \mathrm{~mm}$ long) in radiating clusters originating from olivine microphenocrysts, or as parallel growths from the ends of prismatic plagioclase phenocrysts, and as fine laths $(\sim 0.2$ $\mathrm{mm}$ ) intergrown with prismatic clinopyroxene of a similar size. The composition of these two types of groundmass plagioclase is similar, $\mathrm{An}_{66}$ in Chemical Group I and $\mathrm{An}_{72}$ in Chemical Group II (Table 1).

Eleven samples were analyzed from Hole 562; five from Chemical Group I and six from Chemical Group II. The analyses are given in Table 13 .

Group I basalts plot close to the Di-Hy join in the normative Di-Ol-Hy diagram (Fig. 22); they have only small amounts of normative Ol. The exception to this is Sample 562-2-4, 74-76 cm (Table 13), which is altered (high LOI, $\mathrm{K}_{2} \mathrm{O}, \mathrm{Rb}$ ) and so displaced from the main group by the development of a high Ol/Hy ratio in the norm. Sample 562-1-2, 82-84 cm (Table 13) is also somewhat different chemically from the other samples; it has higher levels of incompatible elements (e.g., $\mathrm{Ti}, \mathrm{Zr}$ ), as well as higher $\mathrm{Ni}$ and $\mathrm{Cr}$, than the other basalts in Group I (Table 13). This sample also has a higher $\mathrm{Di} / \mathrm{Hy}$ ratio (Fig. 22), which cannot be attributed to the effects of alteration. Although significant chemical differences are apparent between this sample and the remainder of Group I, the identification of one aberrant sample is not sufficient to warrant the designation of a separate chemical group, thus this sample will be considered as part of Group I. The basalts of this group are depleted 
Table 13. Major and trace element analyses of Hole 562 basalts.

\begin{tabular}{|c|c|c|c|c|c|c|c|c|c|c|c|}
\hline \multirow{4}{*}{$\begin{array}{l}\text { Chemical group } \\
\text { Core-Section } \\
\text { (interval in cm) } \\
\text { Piece number }\end{array}$} & \multicolumn{5}{|c|}{1} & \multicolumn{6}{|c|}{ II } \\
\hline & $1-2$ & $2-4$ & 3-2 & $4-2$ & $5-3$ & 6-4 & $7-2$ & $8-1$ & $8-2$ & $9-2$ & $10-2$ \\
\hline & $82-84$ & $74-76$ & $141-143$ & $45-47$ & $79-81$ & $18-21$ & $138-142$ & $68-71$ & $55-58$ & $81-83$ & $86-88$ \\
\hline & $4 \mathrm{~b}$ & $2 \mathrm{e}$ & $8 \mathrm{c}$ & $1 \mathrm{~b}$ & If & $1 \mathrm{~b}$ & $4 f$ & $5 c$ & $6 a$ & $4 d$ & $4 \mathrm{~d}$ \\
\hline $\mathrm{SiO}_{2}$ & 49.77 & 48.78 & 49.42 & 49.64 & 49.11 & 48.08 & 47.80 & 47.24 & 47.41 & 48.18 & 45.47 \\
\hline $\mathrm{TiO}_{2}$ & 1.62 & 1.52 & 1.51 & 1.49 & 1.53 & 1.07 & 1.13 & 1.17 & 1.17 & 1.12 & 1.00 \\
\hline $\mathrm{Al}_{2} \mathrm{O}_{3}$ & 15.58 & 15.42 & 15.51 & 15.63 & 14.95 & 17.64 & 16.97 & 15.96 & 15.14 & 16.36 & 16.08 \\
\hline $\mathrm{Fe}_{2} \mathrm{O}_{3}$ & 9.92 & 11.08 & 11.09 & 10.71 & 11.52 & 9.34 & 10.04 & 9.82 & 10.23 & 9.84 & 10.09 \\
\hline $\mathrm{MnO}^{\circ}$ & 0.17 & 0.18 & 0.17 & 0.17 & 0.18 & 0.14 & 0.16 & 0.15 & 0.16 & 0.16 & 0.15 \\
\hline $\mathrm{MgO}$ & 6.16 & 6.75 & 7.08 & 6.69 & 7.47 & 6.62 & 6.80 & 7.25 & 7.14 & 7.50 & 6.18 \\
\hline $\mathrm{CaO}$ & 12.34 & 11.56 & 11.46 & 11.49 & 11.23 & 12.54 & 12.87 & 13.22 & 13.06 & 12.48 & 14.41 \\
\hline $\mathrm{Na}_{2} \mathrm{O}$ & 2.72 & 2.62 & 2.44 & 2.49 & 2.42 & 2.12 & 2.20 & 2.34 & 2.22 & 2.23 & 2.06 \\
\hline $\mathrm{K}_{2} \mathrm{O}$ & 0.29 & 0.29 & 0.20 & 0.22 & 0.14 & 0.28 & 0.15 & 0.27 & 0.33 & 0.24 & 0.41 \\
\hline $\mathrm{P}_{2} \mathrm{O}_{5}$ & 0.15 & 0.14 & 0.14 & 0.14 & 0.14 & 0.11 & 0.12 & 0.12 & 0.12 & 0.11 & 0.11 \\
\hline Lol & 0.87 & 2.09 & 1.30 & 1.51 & 1.58 & 2.58 & 1.99 & 2.13 & 3.39 & 1.85 & 4.48 \\
\hline Total & 99.59 & 100.43 & 100.32 & 100.18 & 100.27 & 100.52 & 100.23 & 99.67 & 100.37 & 100.07 & 100.44 \\
\hline
\end{tabular}

Trace elements in ppm

$\begin{array}{lrrrrrrrrrrr}\mathrm{Cr} & 275 & 248 & 249 & 230 & 236 & 266 & 280 & 271 & 276 & 279 & 248 \\ \mathrm{Ni} & 138 & 96 & 90 & 103 & 90 & 79 & 83 & 117 & 94 & 93 & 86 \\ \mathrm{~V} & 359 & 319 & 316 & 307 & 311 & 260 & 290 & 281 & 296 & 277 & 259 \\ \mathrm{Zn} & 107 & 88 & 89 & 89 & 87 & 75 & 80 & 81 & 82 & 79 & 73 \\ \mathrm{Ga} & 19 & 16 & 16 & 18 & 18 & 17 & 18 & 16 & 17 & 17 & 16 \\ \mathrm{Rb} & 6 & 5 & 4 & 4 & 2 & 6 & 2 & 5 & 8 & 3 & 11 \\ \mathrm{Sr} & 107 & 100 & 98 & 100 & 100 & 96 & 97 & 91 & 98 & 99 & 105 \\ \mathrm{Ba} & 13 & 10 & 11 & 10 & 12 & 12 & 12 & 7 & 12 & 10 & 9 \\ \mathrm{Zr} & 98 & 89 & 92 & 91 & 92 & 63 & 65 & 66 & 67 & 65 & 69 \\ \mathrm{Nb} & 3.0 & 2.9 & 2.9 & 3.0 & 3.1 & 2.4 & 2.4 & 2.8 & 3.2 & 2.4 & 2.6 \\ \mathrm{La} & 3 & 3 & 3 & 3 & 3 & 2 & <2 & 2 & 2 & 2 \\ \mathrm{Ce} & 10 & 10 & 9 & 9 & 10 & 7 & 6 & 7 & 6 & 7 & 7 \\ \mathrm{Nd} & 9 & 9 & 9 & 9 & 8 & 8 & 8 & 8 & 8 & 8 & 7 \\ \mathrm{Y} & 40 & 36 & 36 & 36 & 36 & 26 & 29 & 29 & 30 & 28 & 25\end{array}$

Selected element ratios

$\mathrm{Mg}$-value
$\mathrm{Ti} / \mathrm{Zr}$
$\mathrm{Zr} / \mathrm{Nb}$
$\mathrm{Ce} / \mathrm{Y}_{\mathrm{N}}$
$\mathrm{Zr} / \mathrm{Ce}$
$\mathrm{Zr} / \mathrm{Y}$

$\begin{array}{cc}58 & 58 \\ 99 & 102 \\ 33 & 31 \\ 0.6 & 0.6 \\ 10 & 10 \\ 2.5 & 2.6\end{array}$

59
98
32
0.6
11
2.6

$\begin{array}{cc}58 & 59 \\ 98 & 100 \\ 30 & 30 \\ 0.6 & 0.6 \\ 10 & 10 \\ 2.6 & 2.6\end{array}$

61
102
26
0.6
9.3
2.5

$\begin{array}{cc}60 & 62 \\ 104 & 106 \\ 27 & 24 \\ 0.5 & 0.6 \\ 11 & 9.7 \\ 2.3 & 2.3\end{array}$

$\begin{array}{ccc}61 & 63 & 58 \\ 105 & 103 & 102 \\ 21 & 27 & 23 \\ 0.5 & 0.6 & 0.6 \\ 12 & 10 & 8.7 \\ 2.3 & 2.4 & 2.4\end{array}$

CIPW norms

\begin{tabular}{|c|c|c|c|c|c|c|c|c|c|c|c|}
\hline Or & 1.7 & 1.7 & 1.2 & 1.3 & 0.8 & 1.7 & 0.9 & 1.7 & 2.0 & 1.4 & 2.5 \\
\hline $\mathrm{Ab}$ & 23.4 & 22.5 & 20.8 & 21.3 & 20.7 & 18.3 & 19.0 & 20.3 & 19.4 & 19.2 & 13.5 \\
\hline An & 29.8 & 30.0 & 31.1 & 31.3 & 29.9 & 38.6 & 36.7 & 33.1 & 31.3 & 34.6 & 34.8 \\
\hline $\mathrm{Ne}$ & & & & & & & & & & & 2.5 \\
\hline Di & 25.5 & 22.4 & 20.8 & 21.0 & 20.9 & 19.7 & 22.5 & 27.2 & 28.3 & 22.6 & 31.9 \\
\hline Hy & 11.3 & 11.6 & 18.1 & 18.9 & 18.7 & 12.1 & 8.7 & 0.1 & 4.2 & 9.4 & \\
\hline OI & 2.2 & 5.5 & 1.8 & 0.2 & 2.6 & 4.8 & 7.2 & 12.4 & 9.4 & 7.7 & 9.7 \\
\hline Mt & 1.7 & 2.0 & 1.9 & 1.9 & 2.0 & 1.7 & 1.8 & 1.7 & 1.8 & 1.7 & 1.8 \\
\hline II & 3.1 & 2.9 & 2.9 & 2.9 & 2.9 & 2.1 & 2.2 & 2.3 & 2.3 & 2.2 & 2.0 \\
\hline Ap & 0.4 & 0.4 & 0.3 & 0.3 & 0.4 & 0.3 & 0.3 & 0.3 & 0.3 & 0.3 & 0.3 \\
\hline
\end{tabular}

Note: $\mathrm{LOI}$ is loss on ignition. Total iron is expressed as $\mathrm{Fe}_{2} \mathrm{O}_{3} . \mathrm{CIPW}$ norms and $\mathrm{Mg}$-values $\left(100 \mathrm{Mg} /\left[\mathrm{Mg}+\mathrm{Fe}^{2+}\right]\right)$ are calculated using an assumed $\mathrm{Fe}_{2} \mathrm{O}_{3} / \mathrm{FeO}$ ratio of 0.15 . CeN $/ \mathrm{Y}_{\mathrm{N}}$ expresses the chondrite-normalized ratio of $\mathrm{Ce}$ to $\mathrm{Y}$

in trace elements and have high $\mathrm{Zr} / \mathrm{Nb}$ ratios $(30-33$; Table 13; Fig. 23) and low $\mathrm{Ce}_{\mathrm{N}} / \mathrm{Y}_{\mathrm{N}}$ ratios (0.6; Table 13). Mg-values $(\sim 58)$ and $\mathrm{Cr}$ and $\mathrm{Ni}$ abundances are relatively low, and abundances of the incompatible elements $\mathrm{Ti}$ and $\mathrm{Zr}$ are quite high (Table 13), indicating the relatively evolved nature of these basalts compared to depleted basalts from Chemical Groups I and III, Hole 556; Chemical Group II, Hole 558; and Chemical Group II, Hole 561 (see Figs. 5, 16, 20, 24).

Group II basalts plot in an elongated field in Figure 22 and show a wide variation in the proportion of normative $\mathrm{Hy}$, but an approximately constant $\mathrm{Ol} / \mathrm{Di}$ ratio. Some of this dispersion is due to chemical effects associated with alteration; Samples 562-8-2, 55-58 cm and
$562-10-2,86-88 \mathrm{~cm}$ both have high weight losses on ignition and $\mathrm{K}_{2} \mathrm{O}$ and $\mathrm{Rb}$ contents (Table 13). In addition, the Sample $562-10-2,86-88 \mathrm{~cm}$ has a low Mg-value (Table 13). The former sample is slightly Ne normative, whereas the latter sample has low normative Hy (Fig. 22; Table 13). An additional problem with samples from this group is the presence of a significant proportion of calcite-filled vesicles: Sample 562-8-1, 68-71 cm contains approximately $10 \%$ of these vesicles. The resulting $\mathrm{CaO}$ contamination of the whole-rock analysis will produce a decrease in $\mathrm{Hy}$ in the norm and even the development of normative $\mathrm{Ne}$, although maintaining an approximately constant $\mathrm{Di} / \mathrm{Ol}$ ratio. The basalts of this group are less evolved than those of Group I and have higher 


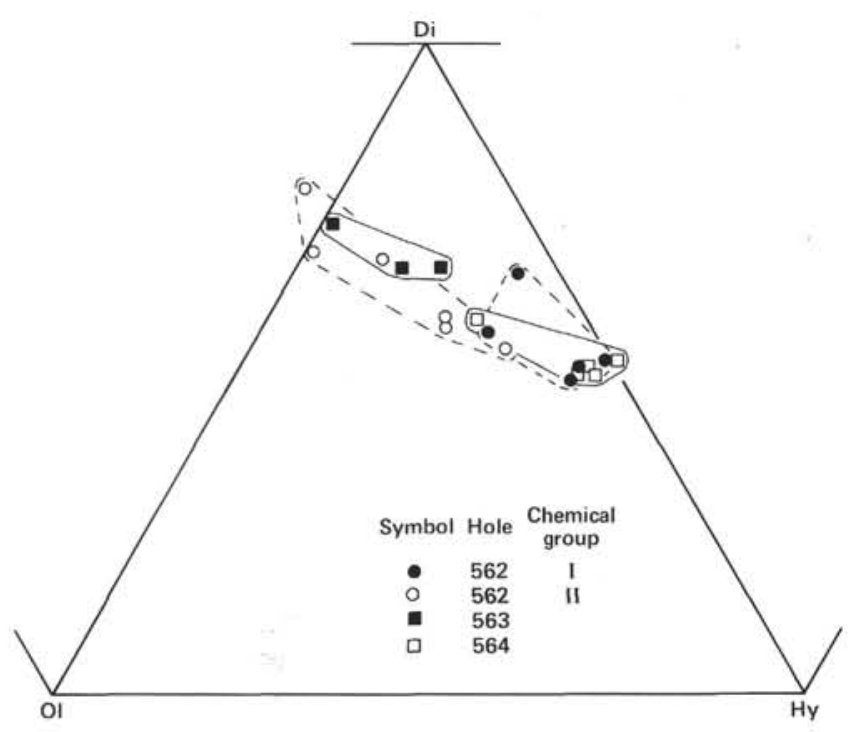

Figure 22. Plot of normative components Ol-Di-Hy in basalts from Holes 562, 563, and 564 .

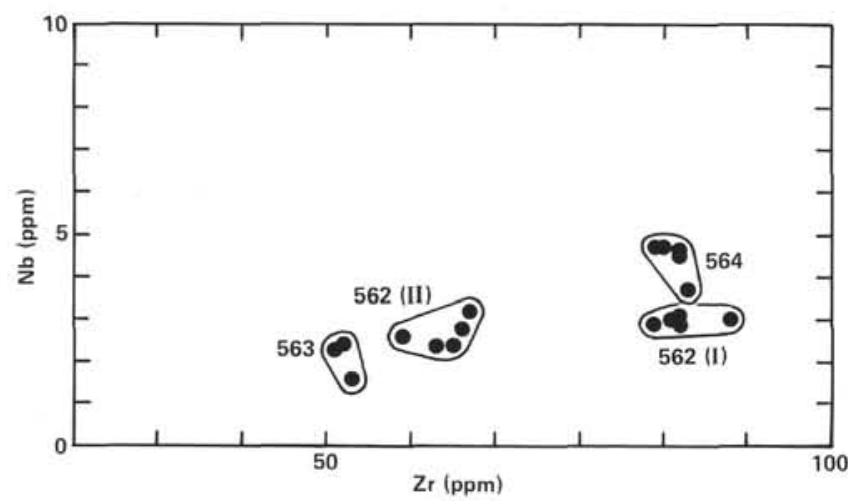

Figure 23. Plot of $\mathrm{Nb}$ versus $\mathrm{Zr}$ for basalts from Holes 562, 563, and 564. Roman numerals indicate chemical groups.

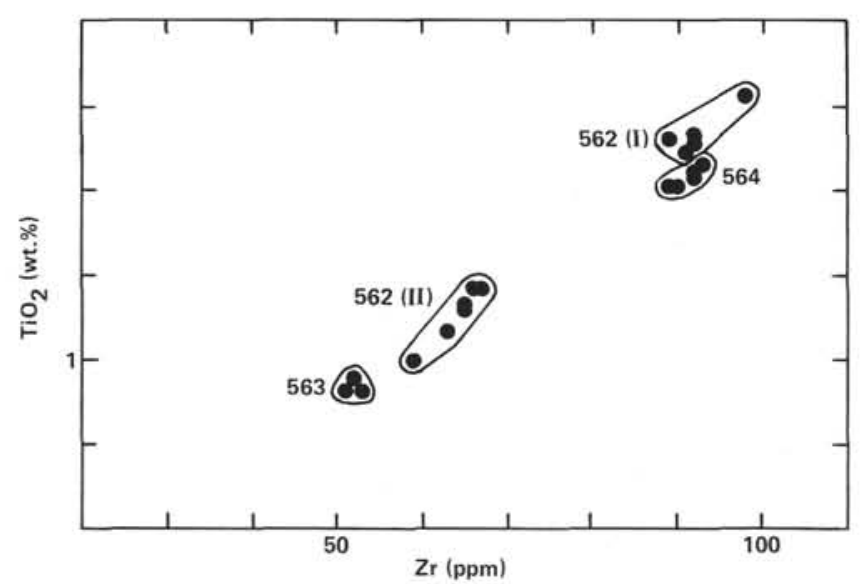

Figure 24. Plot of $\mathrm{TiO}_{2}$ versus $\mathrm{Zr}$ for basalts from Holes 562, 563, and 564. Roman numerals indicate chemical groups.
Mg-numbers, somewhat higher $\mathrm{Cr}$ abundances, and lower $\mathrm{Ti}$ and $\mathrm{Zr}$ abundances (Table 13; Fig. 24). This is in accord with the mineralogic evidence; the Group II basalts have more anorthitic phenocryst and groundmass plagioclase and more forsteritic olivine microphenocrysts (Tables 1,4$)$ than the Group I basalts. However, Group II basalts are similar to Group I in displaying depletion in the more-incompatible elements; $\mathrm{Ce}_{\mathrm{N}} / \mathrm{Y}_{\mathrm{N}}$ ratios are low (0.5-0.6; Table 13), and $\mathrm{Zr} / \mathrm{Nb}$ ratios high (21-27; Table 13), although the latter ratios are lower than in Group I (Fig. 23). The rather wide chemical variation within the Group II basalts (Table 13) can be attributed to dilution by plagioclase phenocrysts (Table 7).

\section{SITE 563}

Site $563\left(33^{\circ} 38.53^{\prime} \mathrm{N} ; 43^{\circ} 46.04^{\prime} \mathrm{W}, 3786 \mathrm{~m}\right.$ water depth) lies on Magnetic Anomaly 13 (37 Ma old) on the west flank of the Mid-Atlantic Ridge and is approximately 60 miles south of the Hayes Fracture Zone on the flow line through Site 562. A single hole was drilled at this site, and only $18 \mathrm{~m}$ of basement (encountered at $364.5 \mathrm{~m}$ sub-bottom depth) were cored before bit failure. The shipboard party identified a single lithologic unit comprising two chemical groups, consisting of sparsely plagioclase phyric pillow basalts.

Plagioclase phenocrysts $(0.5-5 \mathrm{~mm})$ compose approximately $5 \%$ of the basalt and generally occur in glomerophyric clusters. The phenocrysts are lath-shaped to prism-shaped and slightly resorbed; they contain melt inclusions (with $\mathrm{Mg}$-values ranging from 66 to 70 ) and are strongly marginally zoned from core compositions of $\mathrm{An}_{90}$ to rim compositions of $\mathrm{An}_{80}$ (Table 1). Subhedral olivine microphenocrysts have a composition of $\mathrm{Fo}_{85}$ (Table 6). Rare clinopyroxene microphenocrysts (0.3-0.5 $\mathrm{mm})$ occur that are quite magnesian $\left(\mathrm{Mg} /\left[\mathrm{Mg}+\mathrm{Fe}^{2+}\right]\right.$ $=0.84)$ and have high $\mathrm{Cr}_{2} \mathrm{O}_{3}$ contents $(0.77$ wt.\%) (Table 3 ). The groundmass comprises subequal proportions $(\sim 40 \%)$ of randomly oriented, acicular to lathshaped plagioclase of composition $\mathrm{An}_{71}$ (Table 1) and anhedral clinopyroxene $\left(\mathrm{Mg} /\left[\mathrm{Mg}+\mathrm{Fe}^{2+}\right]=0.82\right.$; Table 3 ). The remainder of the groundmass is composed of approximately $3 \%$ equant to granular opaque and approximately $1 \%$ altered granular olivine. The final stage of crystallization is represented by either fine-grained or featherlike arrangements of plagioclase and clinopyroxene. Up to $10 \mathrm{vol} . \%$ calcite-filled vesicles are present.

Only three samples were analyzed from Hole 563, and the data are presented in Table 14 . Normatively the basalts have moderate amounts of $\mathrm{Ol}$ relative to $\mathrm{Hy}$ (Fig. 22) and, in this respect, are similar to the basalts of Chemical Group II, Hole 562 (Fig. 22). However, Ol/Hy ratios may be enhanced by both alteration and calcite contamination, as in Group II, Hole 562. The shipboard party recognized two chemical groups among Hole 563 basalts, although the sole apparent difference is in the abundances of $\mathrm{Fe}_{2} \mathrm{O}_{3}$ and $\mathrm{K}_{2} \mathrm{O}$. Basalts of these two groups occur as interdigitated pillow flows. Our limited number of samples do not conform to this pattern; Sample 563-25-2, 37-39 cm (Piece 2A) (Table 14) has $\mathrm{Fe}_{2} \mathrm{O}_{3}$ and $\mathrm{K}_{2} \mathrm{O}$ abundances similar to Chemical Group I (identified by the shipboard party), although shipboard 
Table 14. Major and trace element analyses for Hole 563 basalts.

\begin{tabular}{|c|c|c|c|}
\hline $\begin{array}{l}\text { Core-Section } \\
\text { (interval in } \mathrm{cm} \text { ) } \\
\text { Piece number }\end{array}$ & $\begin{array}{c}23-1 \\
104-106 \\
10 \mathrm{~b}\end{array}$ & $\begin{array}{c}24-4 \\
0-7 \\
1 \mathrm{a}\end{array}$ & $\begin{array}{c}25-2 \\
37-39 \\
2 a\end{array}$ \\
\hline \multicolumn{4}{|c|}{ Major elements (wt.\%) } \\
\hline $\mathrm{SiO}_{2}$ & 48.50 & 48.04 & 47.69 \\
\hline $\mathrm{TiO}_{2}$ & 0.93 & 0.93 & 0.96 \\
\hline $\mathrm{Al}_{2} \mathrm{O}_{3}$ & 16.23 & 15.58 & 14.96 \\
\hline $\mathrm{Fe}_{2} \mathrm{O}_{3}$ & 9.81 & 9.37 & 10.06 \\
\hline $\mathrm{MnO}^{\circ}$ & 0.16 & 0.16 & 0.17 \\
\hline $\mathrm{MgO}$ & 6.98 & 7.53 & 7.67 \\
\hline $\mathrm{CaO}$ & 13.59 & 13.22 & 14.00 \\
\hline $\mathrm{Na}_{2} \mathrm{O}$ & 2.06 & 2.23 & 2.11 \\
\hline $\mathrm{K}_{2} \mathrm{O}$ & 0.30 & 0.23 & 0.31 \\
\hline $\mathrm{P}_{2} \mathrm{O}_{5}$ & 0.08 & 0.10 & 0.09 \\
\hline LOI & 1.94 & 2.28 & 2.26 \\
\hline Total & 100.58 & 99.67 & 100.28 \\
\hline
\end{tabular}

Trace elements (ppm)

$\begin{array}{lrrr}\mathrm{Cr} & 347 & 344 & 352 \\ \mathrm{Ni} & 98 & 114 & 102 \\ \mathrm{~V} & 318 & 315 & 316 \\ \mathrm{Zn} & 73 & 74 & 76 \\ \mathrm{Ga} & 15 & 16 & 16 \\ \mathrm{Rb} & 5 & 5 & 7 \\ \mathrm{Sr} & 92 & 86 & 87 \\ \mathrm{Ba} & 8 & 7 & 10 \\ \mathrm{Zr} & 51 & 53 & 52 \\ \mathrm{Nb} & 2.3 & 1.6 & 2.4 \\ \mathrm{La} & 2 & 2 & 2 \\ \mathrm{Ce} & 6 & 6 & 6 \\ \mathrm{Nd} & 6 & 7 & 6 \\ \mathrm{Y} & 25 & 25 & 25\end{array}$

Selected element ratios

$\begin{array}{lccc}\text { Mg-value } & 62 & 64 & 63 \\ \mathrm{Ti} / \mathrm{Zr} & 109 & 105 & 111 \\ \mathrm{Zr} / \mathrm{Nb} & 22 & 33 & 22 \\ \mathrm{Ce} / \mathrm{Y}_{\mathrm{N}} & 0.6 & 0.6 & 0.6 \\ \mathrm{Zr} / \mathrm{Ce} & 8.8 & 9.2 & 9.0 \\ \mathrm{Zr} / \mathrm{Y} & 2.1 & 2.2 & 2.2\end{array}$

CIPW norms

\begin{tabular}{lrrr} 
Or & 1.8 & 1.4 & 1.9 \\
$\mathrm{Ab}$ & 17.7 & 19.4 & 18.2 \\
$\mathrm{An}$ & 34.6 & 32.7 & 31.1 \\
$\mathrm{Di}$ & 27.1 & 27.6 & 32.0 \\
$\mathrm{Hy}$ & 7.8 & 5.6 & 0.4 \\
$\mathrm{OI}$ & 6.5 & 8.7 & 11.8 \\
$\mathrm{Mt}$ & 1.7 & 1.7 & 1.8 \\
$\mathrm{II}$ & 1.8 & 1.8 & 1.9 \\
$\mathrm{Ap}$ & 0.2 & 0.3 & 0.2 \\
\hline
\end{tabular}

Note: LOI is loss on ignition. Total iron is expressed as $\mathrm{Fe}_{2} \mathrm{O}_{3}$. CIPW norms and $\mathrm{Mg}$ values $\left(100 \mathrm{Mg} /\left[\mathrm{Mg}+\mathrm{Fe}^{2+}\right]\right)$ are calculated using an assumed $\mathrm{Fe}_{2} \mathrm{O}_{3} / \mathrm{FeO}$ ratio of 0.15 . $\mathrm{Ce}_{\mathrm{N}} / \mathrm{Y}_{\mathrm{N}}$ expresses the chondrite-normalized ratio of Ce to $\mathrm{Y}$.

analysis of the same piece (site chapter, Site 563, this volume) has lower $\mathrm{Fe}_{2} \mathrm{O}_{3}$ and $\mathrm{K}_{2} \mathrm{O}$ typical of Chemical Group II (identified by the shipboard party). We consider only one chemical group to be present in Hole 563 particularly because abundances and abundance ratios of incompatible trace elements do not vary significantly in this hole (Table 14; site chapter, Site 563, this volume). The rather small degree of chemical variation that is present in the basalts of Hole 563 can be attributed to phenocryst dilution. As was the case for Hole 562, the basalts from Hole 563 are depleted in the more-incompatible elements $\left(\mathrm{Zr} / \mathrm{Nb} 22-33, \mathrm{Ce}_{\mathrm{N}} / \mathrm{Y}_{\mathrm{N}} 0.6\right.$; Table 14$)$, but are more primitive than any of the Hole 562 basalts, having somewhat higher $\mathrm{Mg}$-values and $\mathrm{Cr}$ contents (see Tables 13,14) and lower abundances of incompatible elements (e.g., Ti, Zr; Figs. 23, 24).

\section{SITE 564}

Site $564\left(33^{\circ} 44.36^{\prime} \mathrm{N} ; 43^{\circ} 46.03^{\prime} \mathrm{W}, 3820 \mathrm{~m}\right.$ water depth) lies on Magnetic Anomaly $13(37 \mathrm{Ma})$ on the west flank of the Mid-Atlantic Ridge and is approximately 6 miles north of Site 563. Drilling at another site in this area was necessitated by the limited penetration of basaltic basement at Site 563. A single hole was drilled at Site 564 and $81 \mathrm{~m}$ of basement (encountered at $284 \mathrm{~m}$ sub-bottom depth) were cored before the hole was abandoned. A total of five lithologic units composing one chemical group was recognized by the shipboard party, consisting of aphyric pillow basalts and massive basalt flows. The degree of alteration is rather variable.

Although five lithologic units are recognized in this hole, there is little petrographic distinction between units, other than some variation in the proportion of olivine microphenocrysts $\left(\mathrm{Fo}_{83}\right.$; Table 4$)$. The rather peculiar occurrence of domains of contrasting grain size and texture is fully described in the site chapter, Site 564 (this volume).

Analyses for five samples from Hole 564 are given in Table 15 . Normatively they are similar to the basalts of Chemical Group I, Hole 562, and straddle the Di-Hy join (Fig. 22). The analyzed sample (564-3-2, 5-8 cm) is rather altered, having high $\mathrm{LOI}$ and $\mathrm{K}_{2} \mathrm{O}$ and a low Mgvalues. This sample contains appreciably more normative $\mathrm{Ol}$, and less $\mathrm{Hy}$, than the remaining samples (Table 15). The shipboard study indicated an apparent downhole chemical variation in the abundances, and abundance ratios, of some elements (see site chapter, Site 564 , this volume). The density of sampling in this study is not sufficient to confirm this. The basalts from this hole are all depleted in the more-incompatible elements $\left(\mathrm{Zr} / \mathrm{Nb} 19-25, \mathrm{Ce}_{\mathrm{N}} / \mathrm{Y}_{\mathrm{N}}\right.$ 0.6-0.8; Table 15), as are the basalts from Holes 562 and 563, south of the Hayes Fracture Zone. However, there is some indication that the basalts of this hole are rather less depleted than those of Holes 562 and 563, which generally have lower $\mathrm{Ce}_{\mathrm{N}} / \mathrm{Y}_{\mathrm{N}}$ ratios (0.5-0.6) and higher average $\mathrm{Zr} / \mathrm{Nb}$ ratios (Fig. 23). This is particularly the case in comparison to basalts from Chemical Group I, Hole 562, which have equivalent $\mathrm{Mg}$-values and $\mathrm{Ti}$ and $\mathrm{Zr}$ abundances (Fig. 24), but $\mathrm{Zr} / \mathrm{Nb}$ ratio of $30-33$ (Table 13; Fig. 23). The $\mathrm{Ti} / \mathrm{Zr}$ ratio is also lower in Hole 564 basalts than in Hole 562 and 563 basalts (Fig. 24).

\section{CONTROLS ON MORB CHEMISTRY}

Before the chemical characteristics of the mantle sources of erupted basalts can be assessed, the degree of chemical fractionation that can be achieved during partial melting and crystal fractionation processes has to be defined. Any residual fractionation effects that cannot 
Table 15. Major and trace element analyses for Hole 564 basalts.

\begin{tabular}{|c|c|c|c|c|c|}
\hline $\begin{array}{l}\text { Core-Section } \\
\text { (interval in cm) } \\
\text { Piece number }\end{array}$ & $\begin{array}{c}3-2 \\
5-8 \\
1\end{array}$ & $\begin{array}{c}5-2 \\
115-118 \\
4 b\end{array}$ & $\begin{array}{c}6-1 \\
26-28 \\
1 \mathrm{~b}\end{array}$ & $\begin{array}{c}6-4 \\
54-57 \\
2 e\end{array}$ & $\begin{array}{c}7-3 \\
60-63 \\
4 c\end{array}$ \\
\hline \multicolumn{6}{|c|}{ Major elements (wt.\%) } \\
\hline $\mathrm{SiO}_{2}$ & 47.90 & 49.42 & 49.76 & 49.48 & 49.47 \\
\hline $\mathrm{TiO}_{2}$ & 1.41 & 1.41 & 1.46 & 1.43 & 1.44 \\
\hline $\mathrm{Al}_{2} \mathrm{O}_{3}$ & 14.88 & 14.38 & 14.67 & 14.48 & 14.41 \\
\hline $\mathrm{Fe}_{2} \mathrm{O}_{3}$ & 11.97 & 11.73 & 11.27 & 11.81 & 11.60 \\
\hline $\mathrm{MnO}^{\circ}$ & 0.18 & 0.18 & 0.17 & 0.18 & 0.17 \\
\hline $\mathrm{MgO}$ & 6.70 & 7.76 & 7.27 & 7.62 & 7.56 \\
\hline $\mathrm{CaO}$ & 11.82 & 11.28 & 11.32 & 11.25 & 11.19 \\
\hline $\mathrm{Na}_{2} \mathrm{O}$ & 2.32 & 2.26 & 2.35 & 2.36 & 2.38 \\
\hline $\mathrm{K}_{2} \mathrm{O}$ & 0.35 & 0.20 & 0.20 & 0.22 & 0.22 \\
\hline $\mathrm{P}_{2} \mathrm{O}_{5}$ & 0.14 & 0.14 & 0.15 & 0.15 & 0.15 \\
\hline LO้I ${ }^{2}$ & 2.71 & 1.29 & 1.67 & 1.48 & 1.64 \\
\hline Total & 100.38 & 100.05 & 100.29 & 100.46 & 100.23 \\
\hline
\end{tabular}

Trace elements in ppm

$\begin{array}{lrrrrr}\mathrm{Cr} & 267 & 254 & 249 & 241 & 252 \\ \mathrm{Ni} & 104 & 118 & 114 & 121 & 119 \\ \mathrm{~V} & 396 & 380 & 387 & 376 & 382 \\ \mathrm{Zn} & 95 & 89 & 91 & 88 & 92 \\ \mathrm{Ga} & 18 & 17 & 19 & 19 & 18 \\ \mathrm{Rb} & 6 & 3 & 4 & 4 & 3 \\ \mathrm{Sr} & 109 & 102 & 102 & 103 & 107 \\ \mathrm{Ba} & 16 & 18 & 23 & 22 & 24 \\ \mathrm{Zr} & 89 & 90 & 93 & 92 & 92 \\ \mathrm{Nb} & 4.7 & 4.7 & 3.7 & 4.5 & 4.6 \\ \mathrm{La} & 4 & 4 & 5 & 4 & 5 \\ \mathrm{Ce} & 10 & 12 & 10 & 12 & 12 \\ \mathrm{Nd} & 9 & 10 & 9 & 10 & 10 \\ \mathrm{Y} & 36 & 36 & 36 & 35 & 36\end{array}$

Selected element ratios

$\begin{array}{lccccc}\mathrm{Mg} \text {-value } & 56 & 60 & 59 & 59 & 59 \\ \mathrm{Ti} / \mathrm{Zr} & 95 & 94 & 94 & 93 & 94 \\ \mathrm{Zr} / \mathrm{Nb} & 19 & 19 & 25 & 20 & 20 \\ \mathrm{Ce} / \mathrm{Y}_{\mathrm{N}} & 0.6 & 0.8 & 0.6 & 0.8 & 0.8 \\ \mathrm{Zr} / \mathrm{Ce} & 9.3 & 7.8 & 9.7 & 8.0 & 8.0 \\ \mathrm{Zr} / \mathrm{Y} & 2.6 & 2.6 & 2.7 & 2.7 & 2.7\end{array}$

CIPW norms

\begin{tabular}{lrrrrr} 
Q & & & 0.3 & & \\
Or & 2.1 & 1.2 & 1.2 & 1.3 & 1.3 \\
Ab & 20.1 & 19.4 & 20.1 & 20.1 & 20.4 \\
An & 29.8 & 28.9 & 29.3 & 28.6 & 28.4 \\
Di & 24.0 & 22.0 & 21.8 & 22.0 & 22.0 \\
Hy & 11.4 & 21.2 & 21.0 & 19.7 & 20.2 \\
Ol & 6.2 & 1.3 & & 2.1 & 1.4 \\
Mt & 2.1 & 2.1 & 2.0 & 2.1 & 2.0 \\
II & 2.7 & 2.7 & 2.8 & 2.8 & 2.8 \\
Ap & 0.4 & 0.3 & 0.4 & 0.4 & 0.4 \\
\hline
\end{tabular}

Note: LOI is loss on ignition. Total iron is expressed as $\mathrm{Fe}_{2} \mathrm{O}_{3}$. CIPW norms and Mg-values $\left(100 \mathrm{Mg} /\left[\mathrm{Mg}+\mathrm{Fe}^{2+}\right]\right)$ are calculated using an assumed $\mathrm{Fe}_{2} \mathrm{O}_{3} / \mathrm{FeO}$ ratio of 0.15 . $\mathrm{Ce}_{\mathrm{N}} / \mathrm{Y}_{\mathrm{N}}$ expresses the chondrite-normalized ratio of $\mathrm{Ce}$ to $\mathrm{Y}$.

be attributed to these processes can be assigned as source characteristics. Of particular significance in this context are ratios between incompatible trace elements.

\section{Crystal Fractionation}

For the incompatible trace elements, crystal fractionation is an inefficient mechanism for producing large variations in element ratios. This can be demonstrated by considering the variation that can be produced in ratios between elements with $\mathrm{D}=0.1$ and $\mathrm{D}=0.01$. Such bulk distribution coefficients might be appropriate for the elements $\mathrm{Zr}$ and $\mathrm{Nb}$, respectively (Le Roex et al.,
1981). Closed-system Rayleigh crystal fractionation could only produce a decrease in $\mathrm{Zr} / \mathrm{Nb}$ ratio by approximately $20 \%$ after as much as $80 \%$ fractional crystallization. On the other hand, open system crystal fractionation (which is a more realistic process for generating the compositional variation in MORB, if we consider mineralogic and chemical evidence for magma mixing) is more capable of fractionating more-incompatible (e.g., $\mathrm{Nb}$ ) from lessincompatible (e.g., $\mathrm{Zr}$ ) trace elements (O'Hara and Mathews, 1981). The crucial parameter in open-system fractionation is the ratio of the fraction of melt removed (Y) to the fraction of melt crystallized (X) in each cycle. Large fractionation between $\mathrm{Zr}$ and $\mathrm{Nb}$ can only be achieved for very small $\mathrm{Y}(\sim 1 \%)$ and large $\mathrm{X}(\sim 60 \%)$, in which case a decrease in the $\mathrm{Zr} / \mathrm{Nb}$ ratio by a factor of 3.5 can be produced in the steady-state magma relative to the parent magma (from equation 15 in O'Hara and Mathews, 1981). However, in this case, the absolute abundance of the less-incompatible element $(\mathrm{Zr})$ in the steady-state liquid will have increased by a factor of 13 over that in the parent liquid, which is unacceptable for analyses of MORB. Basalts that can be considered as primary mantle-derived magmas parental to most MORB (e.g., Fujii and Bougault, 1983) have approximately 50 ppm $\mathrm{Zr}$, and evolved MORB commonly have approximately 100 ppm $\mathrm{Zr}$ (e.g., evolved basalts from Holes 556 and 558). Hence the absolute enrichment of incompatible elements during fractional crystallization in most MORB is only by a factor of two. This imposes rather severe limits on permissible values of $\mathrm{X}$ and $\mathrm{Y}$ in opensystem behavior, so that it is difficult to achieve more than approximately $20 \%$ variation in $\mathrm{Zr} / \mathrm{Nb}$ ratios. It is clearly not possible to generate the extreme range in $\mathrm{Zr}$ / $\mathrm{Nb}$ ratios in the basalts of Holes 558 and 561 by fractional crystallization in either open or closed systems.

The inadequacy of fractional crystallization mechanisms in generating within-hole variations is well illustrated by the basalts from Hole 558. If we consider only the E-type chemical groups (I, III, IV, V) from this hole, it is very difficult to relate one to another by crystal fractionation. For example, the least-fractionated basalts in Hole 558 are those of Chemical Group V (Fig. 16). However, basalts of Group I (the most primitive in terms of $\mathrm{Ni}$ and $\mathrm{Cr}$ abundances; Figs. 9, 10) have higher concentrations of both incompatible $(\mathrm{Zr})$ and compatible (Ni, Cr) trace elements than Group V basalts (Figs. 9, 10), precluding a simple relationship by crystal fractionation. A similar argument can be made on the basis of the variation of $\mathrm{Sr}$ with $\mathrm{Zr}$ (Fig. 17). In the N-type MORB of Holes 556, 558, 561, 562, 563, and 564, the Sr content is constant at $100-110 \mathrm{ppm}$ irrespective of $\mathrm{Zr}$ abundance. This is a reflection of dominant plagioclase crystallization during the production of evolved N-type MORB. Successful major element models (Table 16) require that plagioclase comprises approximately $50 \%$ of the crystal extract. As $\mathrm{K}_{\mathrm{Sr} \text {. }}^{\mathrm{plag} / \mathrm{liq}}=1.8$ (Le Roex et al., 1981), then $\mathrm{D}_{\mathrm{Sr}}$ approximates 1, resulting in buffering of $\mathrm{Sr}$ abundances. However, in the E-type MORB of Holes $557,558,559$, and $561, \mathrm{Sr}$ abundances are higher than in the N-type MORB and covary in a general way with $\mathrm{Zr}$ content (Fig. 17). Major element models that attempt to relate, for example, Group V basalts to those of Group 
Table 16. Least squares approximations relating basalt groups within Hole 556.

\begin{tabular}{|c|c|c|c|c|c|c|c|}
\hline \multicolumn{8}{|c|}{ Chemical Groups I to II } \\
\hline & $\begin{array}{c}\text { Derivative } \\
(556-3-2,49-51 \mathrm{~cm})\end{array}$ & Ol. & Plag. & Cpx. & $\begin{array}{c}\text { Parent } \\
(556-2-2,132-135 \mathrm{~cm})\end{array}$ & $\begin{array}{l}\text { Calculated } \\
\text { parent }\end{array}$ & Residuals \\
\hline $\mathrm{SiO}_{2}$ & 56.34 & 39.14 & 52.33 & 52.84 & 50.78 & 50.73 & -0.05 \\
\hline $\mathrm{TiO}_{2}$ & 1.43 & & & 0.41 & 1.04 & 1.06 & 0.02 \\
\hline $\mathrm{Al}_{2} \mathrm{O}_{3}$ & 15.98 & & 29.40 & 2.58 & 15.89 & 15.95 & 0.06 \\
\hline $\mathrm{FeO}^{*}$ & 9.46 & 16.43 & 0.71 & 4.93 & 7.71 & 7.78 & 0.07 \\
\hline Mno & 0.18 & & & & 0.15 & 0.13 & -0.02 \\
\hline $\mathrm{MgO}$ & 6.93 & 43.73 & & 18.19 & 8.16 & 8.18 & 0.02 \\
\hline $\mathrm{CaO}$ & 11.50 & 0.33 & 13.84 & 20.42 & 12.61 & 12.70 & 0.09 \\
\hline $\mathrm{Na}_{2} \mathrm{O}$ & 2.69 & & 3.65 & & 2.53 & 2.44 & -0.09 \\
\hline $\mathrm{P}_{2} \mathrm{O}_{5}$ & 0.14 & & & & 0.12 & 0.10 & -0.02 \\
\hline Mix & 70.6 & 2.4 & 14.8 & 12.4 & & \multicolumn{2}{|c|}{$\mathrm{LR}^{2} 0.0281$} \\
\hline \multicolumn{8}{|c|}{ Chemical Groups I to IV } \\
\hline & $\begin{array}{c}\text { Derivative } \\
(556-11-1,106-109 \mathrm{~cm})\end{array}$ & Ol. & Plag. & Cpx. & $\begin{array}{c}\text { Parent } \\
(556-2-2,132-135 \mathrm{~cm})\end{array}$ & $\begin{array}{l}\text { Calculated } \\
\text { parent }\end{array}$ & Residuals \\
\hline $\mathrm{SiO}_{2}$ & 51.32 & 39.14 & 50.90 & 50.99 & 50.78 & 50.77 & -0.01 \\
\hline $\mathrm{TiO}_{2}^{2}$ & 1.34 & & & 0.57 & 1.04 & 0.95 & -0.09 \\
\hline $\mathrm{Al}_{2} \mathrm{O}_{3}$ & 15.29 & & 30.26 & 4.10 & 15.89 & 15.89 & 0.00 \\
\hline $\mathrm{FeO}^{*}$ & 9.56 & 16.43 & 0.72 & 5.86 & 7.71 & 7.74 & 0.03 \\
\hline $\mathrm{MnO}$ & 0.18 & & & & 0.15 & 0.12 & -0.03 \\
\hline $\mathrm{MgO}$ & 6.56 & 43.73 & & 17.03 & 8.16 & 8.15 & -0.01 \\
\hline $\mathrm{CaO}$ & 11.07 & 0.33 & 14.89 & 20.45 & 12.61 & 12.63 & 0.02 \\
\hline $\mathrm{Na}_{2} \mathrm{O}$ & 3.02 & & 3.17 & & 2.53 & 2.53 & 0.00 \\
\hline $\mathrm{P}_{2} \mathrm{O}_{5}$ & 0.14 & & & & 0.12 & 0.09 & -0.03 \\
\hline Mix & 65.2 & 3.6 & 17.8 & 13.5 & & \multicolumn{2}{|c|}{$\Sigma R^{2} 0.0114$} \\
\hline
\end{tabular}

Note: OI. $=$ olivine, $\mathrm{Plag} .=$ plagioclase $\mathrm{Cpx} .=$ clinopyroxene. $\mathrm{FeO} *$ is total iron expressed as $\mathrm{FeO} . \mathrm{LR}^{2}$ is the sum of the squares of residuals (calculated parent - parent). For the least-squares approximations, the method of Bryan et al. (1969) has been used.

III require dominant plagioclase in the crystal extract, which would buffer Sr contents. This and other aspects of the chemistry of Hole 558 basalts strongly suggests that crystal fractionation is not the mechanism responsible for the large chemical variability of basalts in this hole. Nevertheless, it should be noted that some intragroup chemical variation may be related to crystal fractionation, as in the case of Group IIIA and IIIB basalts that do display buffering of Sr.

If extensive subaxial magma chambers through which all MORB were cycled were a feature of the MAR, a strong uniformity of basalt compositions would be expected. It is clear from the data for Hole 558 alone that this is not the case. Although most MORB have undergone some crystal fractionation, and many show evidence for magma mixing, this must occur in small, isolated, and short-lived magma chambers in order for chemical variability such as that observed in Hole 558 to be maintained. This is in accord with geophysical evidence that does not support the concept of a single, large subaxial magma chamber in this region (Nisbet and Fowler, 1978).

\section{Partial Melting}

In contrast to fractional crystallization processes, partial melting is more readily able to produce appreciable variation in ratios of less-incompatible to more-incompatible trace elements. Again, considering elements with $\mathrm{D}=0.1(\mathrm{Zr})$ and $\mathrm{D}=0.01(\mathrm{Nb})$, a variation in the degree of equilibrium batch melting from 5 to $20 \%$ can cause an increase in the $\mathrm{Zr} / \mathrm{Nb}$ ratio by a factor of 2 in the derived liquids. A dynamic melting mechanism (as proposed by Langmuir et al., 1977) for FAMOUS basalts, whereby the source melts incrementally with a fraction of the partial melt retained in the residue at each increment of melting, can cause an increase by a factor of 3 in the $\mathrm{Zr} / \mathrm{Nb}$ ratio from the $5 \%$ to the $20 \%$ melt (with $5 \%$ melt increments and $2 \%$ retained melt). In fact, these figures are probably overestimates of the degree of fractionation that can be attained, because consideration of realistic residual mineralogies coupled with the $\mathrm{K}_{\mathrm{d}}$ data for $\mathrm{Zr}$ of Le Roex and others (1981) suggests that $\mathrm{D}_{\mathrm{Zr}}=$ 0.04 is more reasonable during partial melting. However, there is little indication, in the form of crossing REE patterns, for the operation of dynamic melting as an important process in generating the chemical variability, particularly within-hole, of Leg 82 basalts. Such a model may be applicable to basalts of the FAMOUS area, where LREE-depleted and LREE-enriched basalts have similar ratios of more-incompatible trace elements (e.g., La/Ce; Langmuir et al., 1977), because dynamic melting allows constant ratios of more-incompatible elements while producing decoupling between the abundances of more-incompatible (e.g., LREE) and less-incompatible (e.g., heavy rare earth elements [HREE]) trace elements. However, in Holes 558 and 561, the depleted and enriched groups have different ratios of $\mathrm{La} / \mathrm{Ce}, \mathrm{La} /$ $\mathrm{Ta}$, etc., which cannot be produced by any partial melting process.

In the case of $\mathrm{Zr} / \mathrm{Nb}$ and $\mathrm{Ce} / \mathrm{Y}$ (or $\mathrm{Ce} / \mathrm{Yb}$ ) ratios, consideration of residual garnet in the mantle source al- 
lows more marked fractionation of less-incompatible $(\mathrm{Zr}$, HREE) from more-incompatible (Nb, LREE) trace elements because of the strong preferential concentration of the less-incompatible elements in garnet (Frey et al., 1978; Le Roex et al., 1981). Indeed, in order to explain the variation in $\mathrm{Zr} / \mathrm{Nb}$ ratios in FAMOUS basalts (range 6 to 9.4), Le Roex et al. (1981) proposed that picritic basalts with high $\mathrm{Zr} / \mathrm{Nb}$ ratios equilibrated with garnetfree residues, whereas plagioclase-pyroxene basalts with low $\mathrm{Zr} / \mathrm{Nb}$ ratios were derived by melting of the same source, but at higher pressure and with $8 \%$ residual garnet. It is, however, questionable to what extent garnet can be considered as a realistic residual phase. Fujii and Bougault (1983) have shown that primitive basalts from the FAMOUS area can be derived by partial melting of lherzolite at approximately $10 \mathrm{~kb}$, well above the stability limit for garnet lherzolite. Additionally, partial melts equilibrated with residues containing even quite small amounts $(\sim 2 \%)$ of garnet will show significant depletion in the HREE; melts from sources with as much as $8 \%$ residual garnet would display very strong HREE depletion. There is no evidence from FAMOUS basalts, or any of the Leg 82 basalts, for high $\mathrm{Tb}_{\mathrm{N}} / \mathrm{Yb}_{\mathrm{N}}$ or $\mathrm{Gd}_{\mathrm{N}} /$ $\mathrm{Yb}_{\mathrm{N}}$ ratios (Langmuir et al., 1977; Wood, Tarney, et al., 1979). Some estimate of the degree of melting likely in the production of Hole 558 basalts can be obtained from $\mathrm{Zr}$ abundances. If we accept a primordial mantle abundance for $\mathrm{Zr}$ of $11 \mathrm{ppm}$ (Wood, Joron, et al., 1979) and assume $\mathrm{D}_{\mathrm{Zr}}=0.04$, the degree of partial melting required to generate the range of $\mathrm{Zr}$ abundances in Hole 558 basalts varies from 16 to $8 \%$. However, most of these basalts have undergone significant crystal fractionation that will result in an underestimate of the degree of melting. Even allowing for a degree of melting varying from 20 to $10 \%$ and extreme values for $\mathrm{D}_{\mathrm{Zr}}(0.1)$ and $\mathrm{D}_{\mathrm{Nb}}(0.01)$, the $\mathrm{Zr} / \mathrm{Nb}$ ratio can only vary by a factor of 1.3 during equilibrium partial melting. This contrasts with an observed variation by a factor of 1.6 among the E-type basalts, and by a factor of 3.9 among all of the basalts of Hole 588. If only the E-type basalts were the product of different degrees of batch melting of the same source, the $\mathrm{Zr} / \mathrm{Nb}$ ratio should increase with degree of melting. In fact, the least evolved chemical group (Group V), which has the highest $\mathrm{Mg}$-values and normative olivine content, has a $\mathrm{Zr} / \mathrm{Nb}$ ratio of 7.9 (Table 9), lower than in Groups I and III. Similar arguments could, for example, be applied to the behavior of $\mathrm{La}$ and $\mathrm{Sm}$, and hence the production of variable LREE enrichment/depletion, during partial melting. Although fractionation of elements during partial melting can account for some of the variability in, for example, $\mathrm{Zr} / \mathrm{Nb}$ and $\mathrm{La} / \mathrm{Sm}$ ratios, the wide observed range of these ratios in MORB does require some source heterogeneity for these elements.

\section{DISCUSSION}

Many of the foregoing arguments have demonstrated the inadequacy of partial melting and fractional crystallization processes in producing large differences in incompatible element ratios. Even among those trace elements with quite large differences in $\mathrm{D}$ (e.g., $\mathrm{Zr}$ and $\mathrm{Nb}$;
$\mathrm{La}$ and $\mathrm{Sm}$ ) the variation of element ratios within one hole (i.e., Holes 558 or 561 ) can only be partially attributed to melting processes. On the other hand, ratios among the more-incompatible trace elements closely reflect those of the mantle source, except at very low degrees of partial melting (which are inappropriate when considering MORB genesis). $\mathrm{La}, \mathrm{Ta}$, and $\mathrm{Nb}$ all have very similar bulk distribution coefficients and cannot be fractionated from each other during partial melting (Bougault, Joron, et al., 1979). Similarly, Th is more incompatible than $\mathrm{La}$ or $\mathrm{Ta}$, but ratios between these elements are not modified during partial melting. Thus, ratios using $\mathrm{La}, \mathrm{Ta}$, and $\mathrm{Th}$ abundances in MORB should directly represent those of the mantle source and are indicators of heterogeneity/homogeneity within that source. They do not suffer from the ambiguity inherent in the use of $\mathrm{Zr} / \mathrm{Nb}$ and $\mathrm{La} / \mathrm{Sm}$ ratios.

Previous work in the North Atlantic has suggested that two distinct values for the $\mathrm{La} / \mathrm{Ta}$ ratio exist in MORB (Wood, Tarney, et al., 1979; Bougault et al., 1980; Fig. 25). $\mathrm{N}$-type MORB from the vicinity of the ridge axis at $22-29^{\circ} \mathrm{N}$ and from 110 -Ma-old ocean crust at $25^{\circ} \mathrm{N}$ (Holes 417, 418; Legs 51 to 53) have $\mathrm{La} / \mathrm{Ta}$ ratios close to 17.5 (Wood, Tarney, et al., 1979; Bougault et al., 1980; Bryan et al., 1981). On the other hand, E-type MORB from 63,45 , and $36^{\circ} \mathrm{N}$ all have low $\mathrm{La} / \mathrm{Ta}$ ratios of $\sim 9.25$ (Wood, Tarney, et al., 1979; Bougault et al., 1980 ), a characteristic considered to be related to basalts erupted at anomalous ridge segments and representing large-scale mantle heterogeneity. Even LREE-depleted basalts erupted at these anomalous ridge segments have low $\mathrm{La} / \mathrm{Ta}$ and $\mathrm{Zr} / \mathrm{Nb}$ ratios (e.g., Hole $409,63^{\circ} \mathrm{N}$; Hole

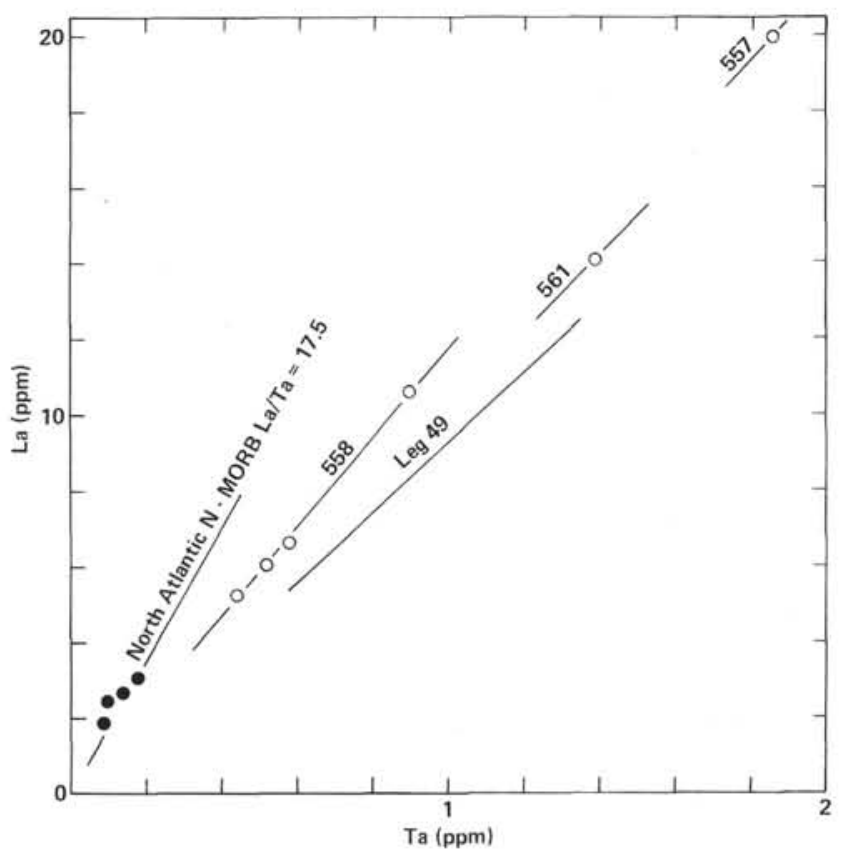

Figure 25. Plot of La versus Ta for Leg 82 basalts (closed circles $=$ $\mathrm{N}$-type MORB from Holes 556, 558, and 561; open circles $=\mathrm{E}-$ type MORB from Holes 557, 558, and 561). Also indicated are $\mathrm{La} /$ Ta ratios for N-MORB from the North Atlantic and for basalts recovered during Leg 49 (Bougault et al., 1980). 
$413,36^{\circ} \mathrm{N}$ [Wood, Tarney, et al., 1979; Bougault et al., 1980]; FAMOUS area [Langmuir et al., 1977]). In contrast, the $\mathrm{Th} / \mathrm{Ta}$ ratio gives a finer resolution of mantle heterogeneities, and for a single $\mathrm{La} / \mathrm{Ta}$ ratio (e.g., E-type MORB from 63,45 , and $36^{\circ} \mathrm{N}$ ), a number of different Th/Ta ratios are defined (Bougault et al., 1980; Fig. 26). The apparent consistency of more-incompatible element ratios in basalts erupted at a given ridge segment led Wood, Tarney, et al., (1979) to conclude that it was unlikely that basalts with the major and trace element characteristics of N-type MORB could ever be erupted at the $36^{\circ} \mathrm{N}$ segment of the MAR.

The data from Leg 82 add an extra degree of complexity to the concept of mantle heterogeneity in the North Atlantic. Clearly, the occurrence of E-type and $\mathrm{N}$-type MORB with distinct $\mathrm{La} / \mathrm{Ta}$ ratios is not a regional feature: the data from Holes 558 and 561 (Table 6) demonstrate that E-type MORB with $\mathrm{La} / \mathrm{Ta}$ ratios of 11-12 and N-type MORB with $\mathrm{La} / \mathrm{Ta}$ ratios of $19-20$ can occur within the same hole. Thus the scale of heterogeneity is localized rather than regional, and mantle sources with both high $\mathrm{La} / \mathrm{Ta}$ and low $\mathrm{La} / \mathrm{Ta}$ ratios can be tapped penecontemporaneously at one small segment of the MAR. This observation also denies that given ridge segments necessarily erupt basalts with a uniform trace element composition over long periods of time. $\mathrm{N}$-type MORB can be erupted from the $36^{\circ} \mathrm{N}$ segment of the MAR and indeed has been erupted from the ridge axis in this region in the recent past ( $35 \mathrm{Ma}$ at Site 558 and $19 \mathrm{Ma}$ at Site 561).

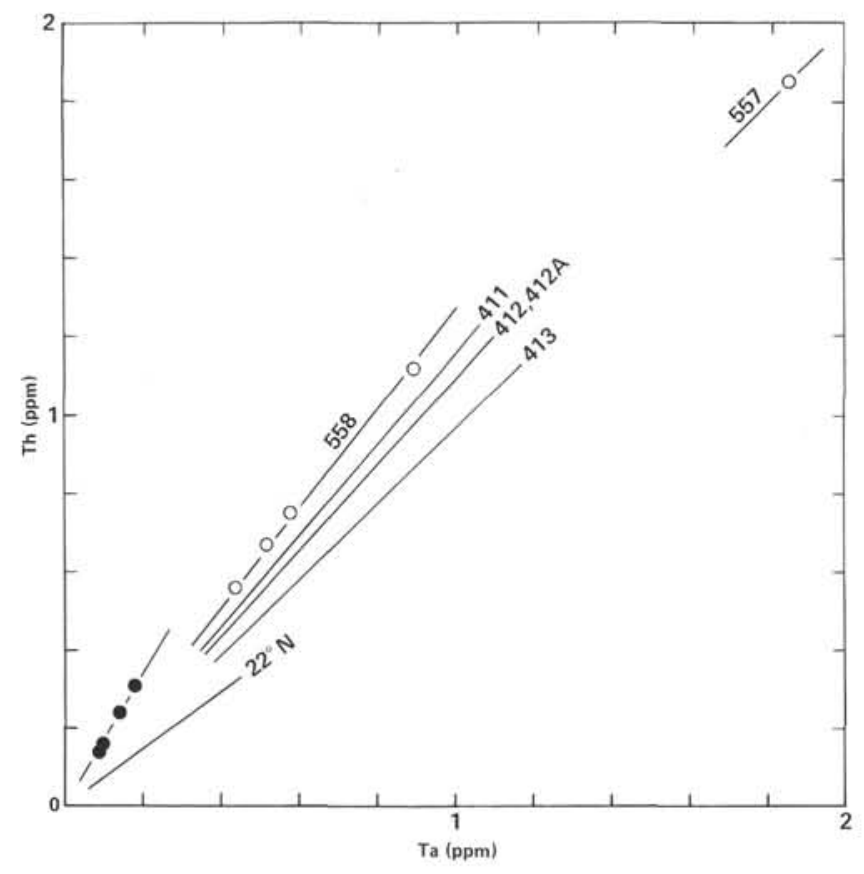

Figure 26. Plot of Th versus Ta for Leg 82 basalts (closed circles $=\mathrm{N}$ type MORB from Holes 556, 558, and 561; open circles = E-Type MORB from Holes 557 and 558). Also indicated are Th/Ta ratios for basalts from Holes $411,412,412 \mathrm{~A}$, and 413 from the FAMOUS area (Bougault et al., 1980) and for N-type MORB from $22^{\circ} \mathrm{N}$ (Bougault, Cambon, et al., 1979).
The demonstration of the very localized nature of the chemical heterogeneities in the suboceanic mantle has considerable implications for models for the production of these heterogeneities. The mantle plume model developed by Schilling and coworkers (Schilling, 1973, 1975; White and Schilling, 1978; Schilling et al., 1980) was erected to explain the large scale heterogeneity in the composition of basalts erupted at the MAR. In this model upwelling mantle plumes, centered under hot spots such as the Azores and Iceland, are the source for E-type MORB. Mixing of this enriched source with depleted upper mantle (the source for N-type MORB) produces basalts with a transitional chemistry dependent upon the proportions of end members. This model relies upon the occurrence of supposed large-scale geochemical gradients away from the hot spots, which reflect the diminishing influence of, and decreasing component from, the plume. However, increasingly detailed drilling in the North Atlantic, and especially the results of Leg 82, cast doubts upon the existence of well-defined chemical gradients away from hot spots. For example, the wide range in $\mathrm{La} / \mathrm{Sm}$ and $\mathrm{Zr} / \mathrm{Nb}$ ratios on a very small scale, i.e., within-hole, is not easily explained by the plume model, particularly as the differences in $\mathrm{La} / \mathrm{Ta}$ ratios precludes production of the variation by dynamic partial melting of a homogeneous mantle source.

Similarly, the chemistry of basalts recovered from systematic sampling of the ocean floor by Leg 82 is not easily explicable in terms of a migrating plume or waxing/waning plume activity. The eruption of N-type MORB at Site 556 would indicate that the Azores plume was not active at $34 \mathrm{Ma}$, and yet E-type MORB was being erupted at Sites 558 and 559 further to the south. However, the occurrence of E-type MORB at Site 557 would suggest that the Azores plume was active by $18-19 \mathrm{Ma}$ and E-type MORB was also being produced at Site 335 (where the basalts are LREE depleted but have low [E-type] $\mathrm{Zr} / \mathrm{Nb}$ and $\mathrm{La} / \mathrm{Ta}$ ratios) and Site 561 to the south. This temporal and spatial variation might be interpreted in terms of a northward-propagating, expanding plume. However, the evidence for very localized mantle heterogeneity is inconsistent with this model. Rather, a model such as that developed by Wood, Joron, and others (1979) and Tarney and others (1980), whereby the depleted suboceanic upper mantle is variably veined by an enriched component, is more capable of explaining the development of local chemical heterogeneities in the mantle.

The results from Leg 82 also indicate the importance of transform faults in delineating mantle domains. The evidence from the sites to the south of the Hayes Fracture Zone (Sites 562 to 564) shows that typical N-type MORB has been erupted in this region since approximately $37 \mathrm{Ma}$, whereas E-type MORB has been erupted at the sites (559 to 561) to the north of the fracture zone. Similarly, evidence from the $24^{\circ} \mathrm{N}$ region of the MAR demonstrates fine-scale isotopic heterogeneity in N-type MORB erupted to the north and south of the Kane Fracture Zone (Machado et al., 1982). It is difficult to envisage how fracture zones could influence the activity of 
mantle plumes. It is perhaps more probable that the fracture zones are delineating regions of oceanic upper mantle that are inherently chemically and isotopically heterogeneous, perhaps because of the veining of the mantle.

\section{REFERENCES}

Arcyana, 1977. Rocks collected by bathyscaph and diving saucer in the FAMOUS area of the Mid-Atlantic Rift valley: petrological diversity and structural setting. Deep-Sea Res., 24:565-589.

Bougault, H., Cambon, P., Corre, O., Joron, J.-L., and Treuil, M., 1979. Evidence for variability of magmatic processes and upper mantle heterogeneity in the axial region of the Mid-Atlantic Ridge near 22 and $36^{\circ} \mathrm{N}$. Tectonophysics, 55:11-34.

Bougault, H., Joron, J.-L., and Treuil, M., 1979. Alteration, fractional crystallisation, partial melting, mantle properties from trace elements in basalts recovered in the North Atlantic. In Talwani, M. (Ed.), Deep Drilling Results in the Atlantic Ocean: Ocean Crust: Washington (American Geophysical Union), pp. 352-368.

1980. The primordial chondritic nature and large scale heterogeneities in the mantle: evidence from high and low partition coefficient elements in oceanic basalts. Phils. Trans. R. soc. London, Ser. A, 297:203-213.

Bougault, H., and Treuil, M., 1980. Mid-Atlantic Ridge: zero-age geochemical variations between Azores and $22^{\circ} \mathrm{N}$. Nature, 286: 209-212.

Bryan, W. B., 1979. Regional variation and petrogenesis of basalt glasses from the FAMOUS area, Mid-Atlantic Ridge. J. Petrol., 20:293-325.

Bryan, W. B., Finger, L. H., and Chayes, F., 1969. Estimating proportions in petrologic mixing equations by least squares approximation. Science, 163:926-927.

Bryan, W. B., Thompson, G., and Ludden, J. N., 1981. Compositional variation in normal MORB from $22^{\circ}-25^{\circ} \mathrm{N}$ : Mid-Atlantic Ridge and Kane Fracture Zone. J. Geophys. Res., 86:11815-11836.

Clague, D. A., Frey, F. A., Thompson, G., and Rindge, S., 1981. Minor and trace element geochemistry of volcanic rocks dredged from the Galapagos spreading centre: role of crystal fractionation and mantle heterogeneity. J. Geophys. Res., 86:9469-9482.

Clarke, D. B., and Loubat, H., 1977. Mineral analysis from the peridotite-gabbro-basalt complex at Site 334, DSDP Leg 37. In Aumento, F., Melson, W. G., et al., Init. Repts. DSDP, 37: Washington (U.S. Govt. Printing Office), 847-855.

Frey, F. A., Green, D. H., and Roy, S. D., 1978. Integrated models of basalt petrogenesis: A study of quartz tholeiites to olivine melilites from South Eastern Australia utilizing geochemical and experimental petrological data. J. Petrol., 19:463-513.

Fujii, T., and Bougault, H., 1983. Melting relations of a magnesian abyssal tholeiite and the origin of MORB's. Earth Planet. Sci. Lett., 62:283-295.

Hart, R. A., 1970. Chemical exchange between seawater and deep ocean basalts. Earth Planet. Sci. Lett., 9:269-279.

Hart, S. R., 1971. K, Rb, Cs, $\mathrm{Sr}$ and $\mathrm{Ba}$ and $\mathrm{Sr}$ isotope ratios of ocean floor basalts. Phils. Trans. R. Soc. London Ser. A, 268:573-588.

Hart, S. R., Erlank, A. J., and Kable, E. D. J., 1974. Sea floor basalt alteration: some chemical and $\mathrm{Sr}$ isotopic effects. Contrib. Mineral. Petrol., 44:219-230.

Hart, S. R., Schilling, J.-G., and Powell, J. L., 1973. Basalts from Iceland and along the Reykjanes Ridge: $\mathrm{Sr}$ isotope geochemistry. $\mathrm{Na}$ ture, 246:104-107.

Langmuir, C. H., Bender, J. F., Bence, A. E., Hanson, G. N., and Taylor, S. R., 1977. Petrogenesis of basalts from the FAMOUS area: Mid-Atlantic Ridge. Earth Planet. Sci. Lett., 36:133-156.

Le Roex, A. P., Dick, H. J. B., Reid, A. M., and Erlank, A. J., 1982. Ferrobasalts from the Speiss Ridge segment of the Southwest Indian Ridge. Earth Planet. Sci. Lett., 60:437-451.

Le Roex, A. P., Erlank, A. J., and Needham, H. D., 1981. Geochemi$\mathrm{cal}$ and mineralogical evidence for the occurrence of at least three distinct magma types in the 'FAMOUS' region. Contrib. Mineral. Petrol., 77:24-37.

Machado, N., Ludden, J. N., Brooks, C., and Thompson, G., 1982. Fine-scale isotopic heterogeneity in the sub-Atlantic mantle. $\mathrm{Na}$ ture, 295:226-228.
Marsh, N. G., Saunders, A. D., Tarney, J., and Dick, H. J. B., 1980. Geochemistry of basalts from the Shikoku and Daito basins, Deep Sea Drilling Project Leg 58. In Klein, G., de V., Kobayashi, K., et al., Init. Repts. DSDP, 58: Washington (U.S. Govt. Printing Office), $805-842$.

Nakamura, N., 1974. Determination of REE, Ba, Fe, Mg, Na and K in carbonaceous and ordinary chondrites. Geochim. Cosmochim. Acta, 38:757-775.

Nisbet, E. G., and Fowler, C. M. R., 1978. The Mid-Atlantic Ridge at $37^{\circ}$ and $45^{\circ} \mathrm{N}$ : some geophysical and petrological constraints. Geophys. J. R. Astron. Soc., 54:631-660.

O'Hara, M. J., and Mathews, R. E., 1981. Geochemical evolution in an advancing, periodically replenished, periodically tapped, continuously fractionated magma chamber. J. Geol. Soc. London, 138:237-277.

Saunders, A. D., 1983. Geochemistry of basalts recovered from the Gulf of California during Leg 65 of the Deep Sea Drilling Project. In Lewis, B. T. R., Robinson, P., et al., Init. Repts. DSDP, 65: Washington (U.S. Govt. Printing Office), 591-621.

Schilling, J.-G., 1971. Sea-floor evolution: rare earth evidence. Phils. Trans. R. Soc. London, Ser. A, 286:663-706.

1973. Iceland mantle plume: geochemical study of the Reykjanes Ridge. Nature, 242:565-571.

1975. Azores mantle blob: rare-earth evidence. Earth Planet. Sci. Lett., 25:103-115.

Schilling, J.-G., Bergeron M. B., and Evans, R., 1980. Halogens in the mantle beneath the North Atlantic. Phils. Trans. R. Soc. London, Ser. $A, 297: 147-178$.

Sigurdsson., H. 1981. First-order major element variation in basalt glasses from the Mid-Atlantic Ridge: $29^{\circ} \mathrm{N}$ to $73^{\circ} \mathrm{N}$. J. Geophys. Res., 9483-9502.

Symes, R. F., Bevan, J. C., and Hutchison, R., 1977. Phase chemistry studies on gabbro and peridotite rocks from Site 334, DSDP Leg 37, In Aumento, F., Melson, W. G., et al., Init. Repts. DSDP, 37: Washington (U.S. Govt. Printing Office), 841-845.

Tarney, J. Saunders, A. D., Weaver, S. D., Donnellan, N. C. B., and Hendry, G. L., 1979. Minor-element geochemistry of basalts from Leg 49, North Atlantic Ocean. In Luyendyk, B. P., Cann, J. R., et al., Init. Repts. DSDP, 49: Washington (U.S. Govt. Printing Office), 657-691.

Tarney, J., Wood, D. A., Saunders, A. D., Conn, J. R., and Varet, J., 1980. Nature of mantle heterogeneity in the North Atlantic: evidence from Deep Sea Drilling. Phils. Trans. R. Soc. London, Ser. A, 297:179-202

Thompson, G. and Humphris, S., 1977. Seawater-rock interactions in the oceanic basement. Proc. 2nd Inter. Symp. Water-Rock Interaction (Vol. III), 3-8.

Vanko, D. A., and Batiza, R., 1982. Gabbroic rocks from the Mathematician Ridge failed rift. Nature, 300:742-744.

Weaver, B. L., Marsh, N. G., and Tarney, J., 1983. Trace element geochemistry of basaltic rocks recovered at Site 516, Rio Grande Rise, Deep Sea Drilling Project Leg 72. In Barker, P. F., Carlson, R. L., Johnson, D. A., et al., Init. Repts. DSDP, 72: Washington (U.S. Govt. Printing Office), 451-466.

White, W. M., and Schilling, J.-G., 1978. The nature and origin of geochemical variation in Mid-Atlantic Ridge basalts from the central North Atlantic. Geochim. Cosmochim. Acta, 42:1501-1516.

White, W. M., Schilling, J.-G., and Hart, S. R., 1976. Evidence for the Azores mantle plume from strontium isotope geochemistry of the Central North atlantic. Nature, 263:659-663.

Wood, D. A., 1978. Major and trace element variations in the Tertiary lavas of East Iceland and their significance with respect to the Iceland geochemical anomaly. J. Petrol., 19:393-436.

Wood, D. A., Joron, J.-L., Treuil, M., Norry, N., and Tarney, J. 1979. Elemental and $\mathrm{Sr}$ isotope variations in basic lavas from Iceland and the surrounding ocean floor. Contrib. Mineral. Petrol., 70: 319-339.

Wood, D. A., Tarney, J., Varet., J., Saunders, A. D., Bougault, H., Joron, J.-L., Treuil, M., and Cann, J. R., 1979. Geochemistry of basalts drilled in the North Atlantic by IPOD Leg 49: implications for mantle heterogeneity. Earth Planet. Sci. Lett., 42:77-97.

Date of Initial Receipt: 19 April 1983

Date of Acceptance: 11 November 1983 